\title{
Archeological Investigations in the Upper Trinity River Basin in Parker County, Texas
}

Timothy K. Perttula

Heritage Research Center, Stephen F. Austin State University

Karen S. Bruwelheide

Douglas Owsley

Lanie Garmon

Follow this and additional works at: https://scholarworks.sfasu.edu/ita

Part of the American Material Culture Commons, Archaeological Anthropology Commons, Environmental Studies Commons, Other American Studies Commons, Other Arts and Humanities Commons, Other History of Art, Architecture, and Archaeology Commons, and the United States History Commons

Tell us how this article helped you.

This Article is brought to you for free and open access by the Center for Regional Heritage Research at SFA ScholarWorks. It has been accepted for inclusion in Index of Texas Archaeology: Open Access Gray Literature from the Lone Star State by an authorized editor of SFA ScholarWorks. For more information, please contact cdsscholarworks@sfasu.edu. 


\section{Archeological Investigations in the Upper Trinity River Basin in Parker County,}

Texas

\section{Creative Commons License}

\section{(c) (1) (9)}

This work is licensed under a Creative Commons Attribution-NonCommercial 4.0 International License 


\section{Archeological Investigations in the Upper Trinity River Basin in Parker County, Texas}

Timothy K. Perttula, with contributions

by Karin S. Bruwelheide and Douglas Owsley and a Preface by Lanie Garmon

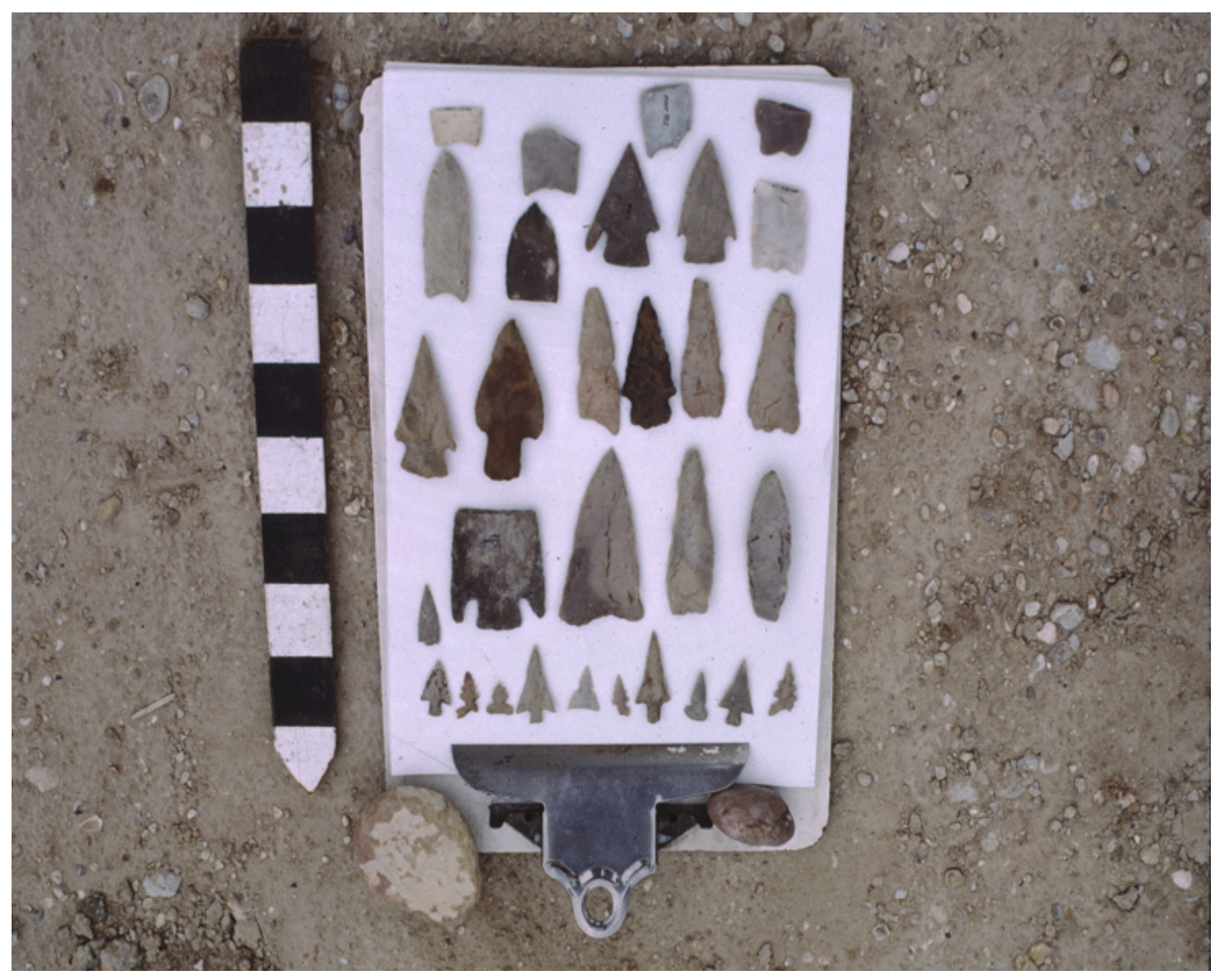

Special Publication No. 58

Friends of Northeast Texas Archaeology

Special Publication No. 1, North Texas Archeological Society 
Editor, Timothy K. Perttula

10101 Woodhaven Dr.

Austin, Texas 78753

tkp4747@aol.com

Copyright 2020, Friends of Northeast Texas Archaeology and North Texas Archeological Society

All rights reserved. 


\section{Table of Contents}

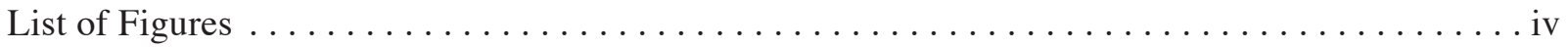

Acknowledgments $\ldots \ldots \ldots \ldots \ldots \ldots \ldots \ldots \ldots \ldots \ldots \ldots \ldots \ldots \ldots \ldots \ldots \ldots \ldots \ldots \ldots$

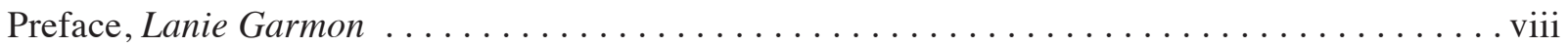

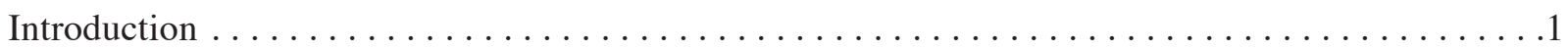

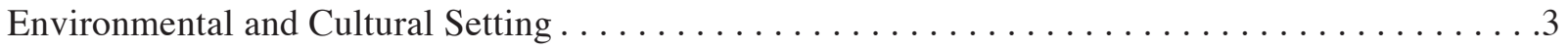

Investigated Archeological Sites and Collections. .......................

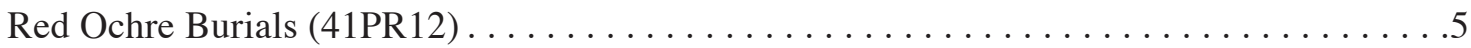

Ancient Conflict and Ritual in North Central Texas, Karin S. Bruwelheide and Douglas W. Owsley ................................11

Use of Red Ochre in Native American Burial Rites in Texas. . . . . . . . . . . . . . . 17

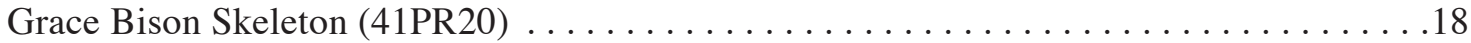

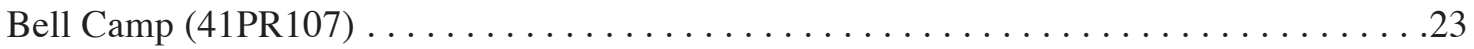

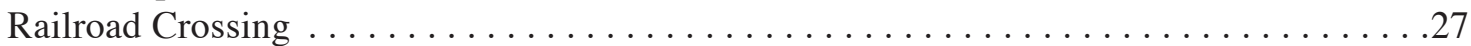

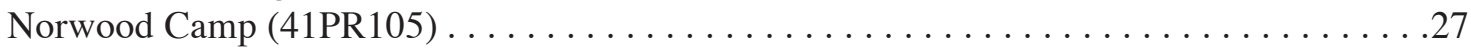

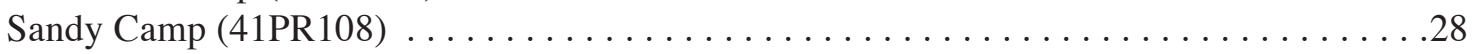

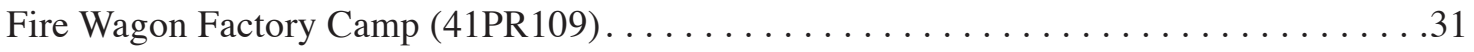

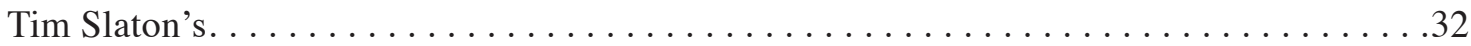

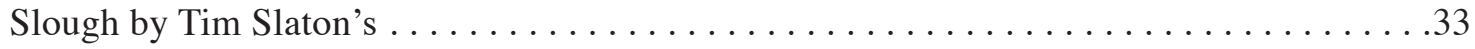

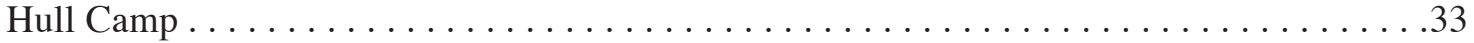

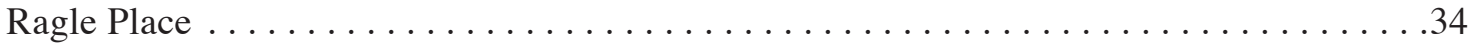

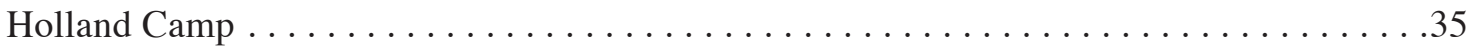

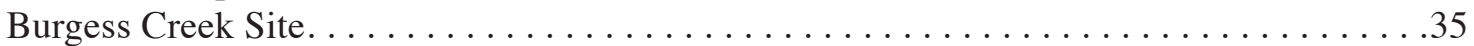

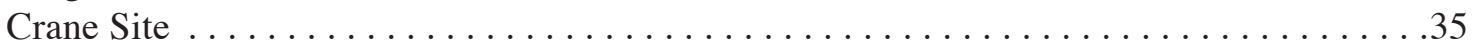

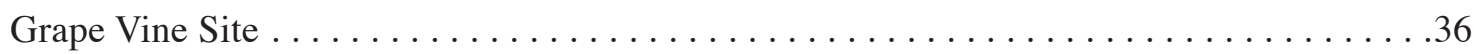

Negro School Site . . . . . . . . . . . . . . . . . . . . . . . . . .

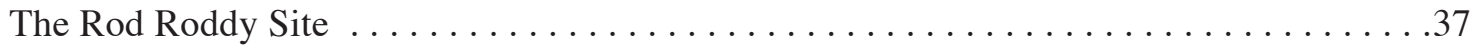

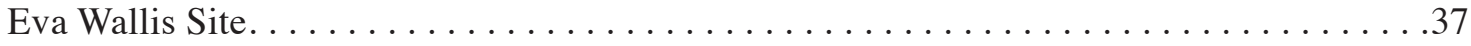

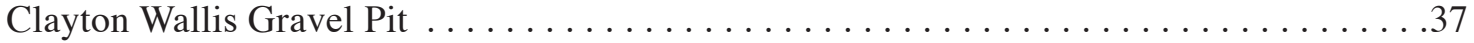

South Fork Hearth I. . . . . . . . . . . . . . . . . . . . . . . . . . . . . 39

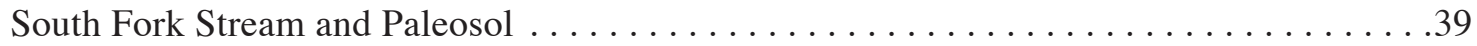

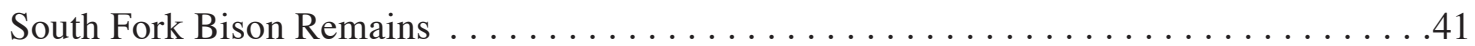

Clear Fork Stream Finds . . . . . . . . . . . . . . . . . . . . .

Summary of the Investigations by Homer Norris in Parker County $\ldots \ldots \ldots \ldots \ldots \ldots \ldots \ldots$

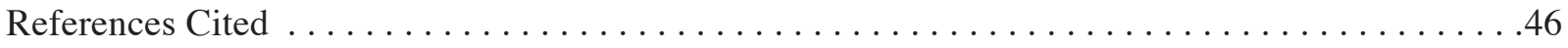




\section{List of Figures}

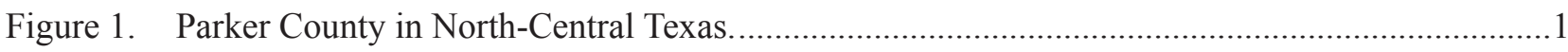

Figure 2. Map of the Annetta-Aledo area of Parker County, Texas, and selected general site locations......2

Figure 3. Views of the South Fork of the Trinity River landscape: a, pasture and woodlands; b, upland

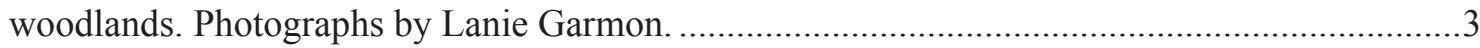

Figure 4. Looking east at the area of the Red Ochre Burials site. Photograph by Lanie Garmon. ..............5

Figure 5. Looking south at Bell Camp and the area of the Red Ochre Burials is to the right past the

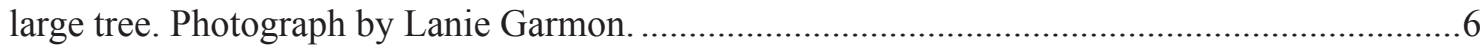

Figure 6. Plan map of Burial 1 at the Red Ochre Burials site. Drawing by Homer Norris..........................7

Figure 7. Plan map of excavation units at the Red Ochre Burials site. .................................................7

Figure 8. Excavations in midden area west and northwest of Burial 1 at the Red Ochre Burials site: a, excavated units with gravel pit in the background; $b$, view northwest of test units, with thin midden deposit in unit wall; c, view of western excavation units; charcoal pedestaled in the background; d, Larry Banks excavating a test unit at the site. Photographs a-c courtesy of the Texas Historical Commission; d, courtesy of James Everett.

Figure 9. Probability distributions of the two calibrated radiocarbon dates from 41PR12 ......................10

Figure 10a-b. Fossil oyster shell fragments of the genus Gryphaea found in the surrounding matrix and

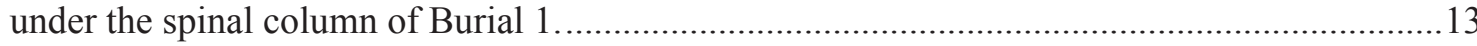

Figure 11a-b. Both sides of broken projectile points found in the chest region of Burial 2 …...................15

Figure 12. Pebbles and nodules of goethite, a hydrated form of iron oxide that can be used as a pigment (brown ochre).

Figure 13. Looking north from Bell Camp and the area of the Red Ochre Burials site towards the Grace Bison Skeleton site (41PR20) in the far left of the photograph. Photography by Lanie Garmon

Figure 14. Plan of the Grace bison skeleton at 41PR20. Drawing by Homer Norris.................................19

Figure 15. Photograph of the exposed bison skeleton at 41PR20 .....................................................20

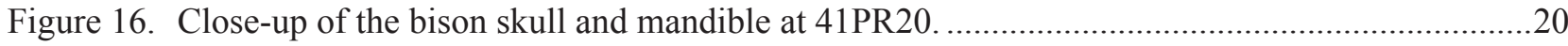

Figure 17. Close up of the lower rib cage and back legs of the bison skeleton at 41PR20........................21

Figure 18. Selected chipped stone tools from the Grace Bison Skeleton site. Drawings by Homer Norris...21

Figure 19. Edgewood point from the surface of the Grace Bison Skeleton site (41PR20)........................22

Figure 20. Selected arrow points from 1973-1975 excavations by Homer Norris at the Bell Camp site.

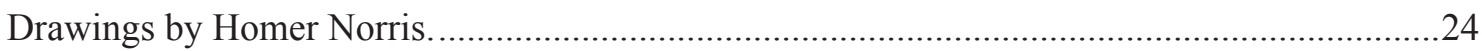

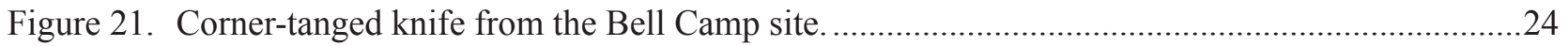

Figure 22. Washita, var. Norris side notched arrow points from the Bell Camp site. Illustration provided

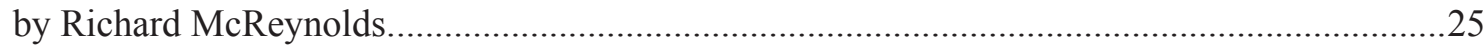

Figure 23. Washita, var. Norris arrow points from 41PR126. Photograph courtesy of James Everett. ........25 
Figure 24. Early Caddo period ceramic vessel sherds from the Bell Camp and Railroad Crossing sites: a, e, fingernail punctated body sherd; b, Weches Fingernail Impressed rim sherd; c, Davis Incised rim sherd; d, Crockett Curvilinear Incised body sherd; f, Pennington Punctated-Incised body sherd; g, Crockett Curvilinear Incised body sherd; h, cane punctated body sherd. Drawings by Homer Norris.

Figure 25. Selected artifacts from the Railroad Crossing site. Drawings by Homer Norris. .27

Figure 26. Selected artifacts from the Norwood Camp site. Drawings by Homer Norris. .28

Figure 27. Scratched and abraded piece of red ochre from the Norwood camp site. Photograph by Lanie Garmon.

Figure 28. Plan map of the burial at the Sandy Camp site.

Figure 29. Selected dart points and tools found at the Sandy Camp site. Drawings by Homer Norris. 30

Figure 30. Plan of burned rock feature and associated burned rock scatter in Units A-C at the Sandy Camp site. Drawing by Homer Norris. .31

Figure 31. Selected artifacts from the Fire Wagon Factory Camp. Drawings by Homer Norris. 32

Figure 32. Selected artifacts from Tim Slaton's site. Drawings by Homer Norris. 33

Figure 33. Selected lithic artifacts from the Hull Camp site. Drawings by Homer Norris. .34

Figure 34. Selected artifacts from the Ragle Place site. Drawings by Homer Norris. .34

Figure 35. Dart points from the Holland Camp site. Drawings by Homer Norris. .35

Figure 36. Ellis dart point from the Burgess Creek site. Drawing by Homer Norris. .36

Figure 37. Late Archaic dart points from the Grape Vine site. Drawings by Homer Norris. .36

Figure 38. Selected artifacts from the Negro School site. Drawings by Homer Norris. .37

Figure 39. Selected artifacts from the Rob Roddy site. Drawings by Homer Norris. .38

Figure 40. Chert biface from the Clayton Wallis Gravel Pit. 38

Figure 41. Folsom point from the South Fork of the Trinity River. Drawing by Homer Norris. 39

Figure 42. Selected dart points from gravel beds along the South Fork of the Trinity River. Drawings by Homer Norris.

Figure 43. Additional Paleoindian and Archaic dart points from gravel beds along the South Fork of the Trinity River. Drawings by Homer Norris.

Figure 44. Selected Archaic dart points and tools from South Fork of the Trinity paleosol deposits. Drawings by Homer Norris.

Figure 45. Range of artifacts found in paleosol deposits from the South Fork of the Trinity River.......

Figure 46. Possible Hell Gap or Angostura point from Clear Fork of the Trinity River gravels.

Figure 47. Selected artifacts from the Clear Fork of the Trinity River gravel beds. Drawings by Homer Norris. 



\section{Acknowledgments}

This study could not have been completed without the efforts and support of Lanie Garmon, daughter of Homer Norris. She not only encouraged the study, but provided many pages of invaluable notes and manuscripts prepared by Mr. Norris, as well as photographs of artifacts she was able to match to Norris drawings in his notes. Mike Grace allowed Perttula to examine his artifact collections from the Grace Bison site (41PR20). James Everett provided PDFs of two articles he wrote for the Tarrant County Archeological Society on work done at 41PR12 and 41PR20, along with a number of photographs, and Drew Sitters shared Texas Historical Commission (THC) photographs of the 1985 work at $41 \mathrm{PR} 12$ that he found on the THC server; he also transported artifact boxes from the Parker County collections. Dan Prikryl, Dan McGregor, Jay Newman, James Everett, and Bryan Jameson provided information about other North Central Texas sites with Washita, var. Norris arrow points. S. Chris Sagebiel of the Vertebrate Paleontology Laboratory at The University of Texas at Austin found the radiocarbon forms for 41PR12. Thomas R. Hester, Ron Ralph, and Tom Speir provided information on aboriginal red ochre burials in Texas. Lance Trask prepared Figure 1 in this study, while Brian Wootan prepared many others. 


\title{
Preface by Lanie Garmon
}

\author{
O'er fields of now-turned sod, \\ Communing with my God, \\ I tramped alone, \\ And in a furrow bed \\ I found an arrowhead \\ Chiseled from stone. \\ - (Enos. B, “A Boy’s Life”)
}

Had prehistoric peoples living in the Annetta, Texas, valley wanted their memory to live into modern times, they could not have hoped for a better man than Homer Norris - my father-to give warm life and voice to the stone tools and dry bones they left behind.

Not only was my father an accomplished artist, sensitive historian, and natural teacher, he found life-long solace along the Trinity River tributaries, the Clear Fork and South Fork creeks, that were the life blood of ancient people migrating through North Central Texas. The ancients were very real people to Homer from a young age, and finding the clues they left behind became his passion.

From an early age, I knew our valley was unique and rich in history, and that my dad had a special, intimate, connection with it. Many people visited our hilltop home in Annetta, a home he and my mom Rosemary built by hand, to marvel over his carefully curated artifacts in the studio where he worked as a commercial artist, the meticulously labeled ancient artifacts arranged in cases by time periods and on their appropriate soil type, most found within a three-mile radius of our home.

I was much in awe of these cases as a child and as an adult. There was a Pleistocene era mammoth tusk and tooth found in the gravel pit across from our home, Bison antiquus and Bison latifrons skulls, stone tools and animal bones from what he called "archaic alley," as well as projectile points from all three Paleoindian time periods: Clovis, Folsom and Late Paleoindian. Homer proclaimed in our local newspaper, "Not many towns can claim host to the earliest man known in the western hemisphere...we can.”

My father viewed his self-curated collections as a source of community pride, and loved talking to local school kids every year or having them to our home where they could see prehistoric specimens up close, even hold them in their hands. He frequently referred to knowledge of local history as "lifegiving," and I have observed it to be true.

Dad took his children with him to the creeks and Indian campsites, talking all the while about creek morphology and lithic artifact deposits while imparting practical tips for avoiding bull nettle and water moccasins. "Dropping down into the creek bed is dropping out of the present and back into history," Dad often said. I can't cross either creek today without remembering.

I once lagged behind him in the Clear Fork on a hot summer afternoon, and coming around a bend I beheld what looked like only his cowboy hat floating in place in the stream. Then with relief I realized he was floating in the shallow stream, boots and all, his hat covering his face, cooling off while patiently waiting for me.

These are my best memories of childhood. 
It was not until after my father died in October 2018, in his hilltop home overlooking the creek, that I had the profound privilege of reading through his years of journals, letters, and sketches. I began to understand the scope and depth of his devotion to the systematic recording of prehistoric sites so their stories could be preserved and told in more depth.

Many of the sites named in this publication were quite specifically home to people my father loved, people who helped one another survive through difficult, lean times, and who are now long gone. His memories of Nettie Bell of "Bell Camp" or Tim Slaton of the "Slaton Site" are just as compelling as his careful, meticulous recording of archeological discoveries on their land:

This site was named for Mrs. Nettie Bell, who owned the land. When I was 10 years old, we lived in a stone house just outside the east boundary of her little sandy hill. Bell Camp was the beginning of my passion for Indian artifacts and prehistory. One day I was playing with a little kitchen sifter in the southwest corner of our place. Suddenly I found myself staring at a curious little piece of art, a 'Cuney' style arrowhead! As soon as I had sifted all the sand in this little basin, I moved under the fence and started there. On about the third day, I began to walk around in the field, which had been plowed and then washed by a recent rain. Immediately I found many things: a broken corner-tang knife, two beautifully worked drills, two triangular bifaces, many little arrow points. Thus I became a classic 'Pot-hunter.' Nettie Bell died this year [1990] and while she never allowed professionals to come onto her land and survey, she welcomed me, and I hope my records will in some small way suffice to say ancient peoples lived here.

One can only imagine Homer's delight some 46 years later when his young son John Norris would discover the red ochre burial site (41PR12) in almost the same exact spot while out riding his bike! A professional excavation was then performed, first reported by James Everett, and now included in more detail in this publication.

Only a few months later and three miles to the northwest, a bison believed by Homer to have been ceremonially buried was found by Mike and Ann Grace at the Grace Bison site (41PR20), who called Homer because of his involvement in the red ochre site. He participated fully in the excavation of the young bison, wrote copious notes and drew the bison in situ, which he published in his Parker County Prairie Sketchbook. The drawing is now displayed with the original skeleton at the Doss Heritage Center in Weatherford, Texas.

Because of his interest in, and gratitude for, those that came before him and his desire to tell their stories, Homer created for himself and his family a warm sense of community and wonder for the natural world that sustained him as a child. I retain these gifts from him and am grateful for them.

I owe Timothy K. Perttula a debt of great gratitude for writing this publication, and all that it demanded to do so, from reading through hundreds of pages of Dad's handwritten notes and drawings, searching out facts on the numerous sites Dad wrote about, filling in missing details, going through many boxes of artifacts to find those of relevance, and educating me about the ways of the archeologist.

I also want to thank the North Texas Archeological Society, for both their friendship and interest in Dad's work, as well as support for this publication. Special thanks to Marvin Glasgow for formally recording some of Dad's sites and other sites in east Parker County, and for his and Dina's enduring friendship. 



\section{Introduction}

A lot of people collect, but Homer keeps accurate, detailed records of everything. Everything is cataloged. He can tell you exactly where it came from and give detailed information about the area. And since he is an artist, he has the ability to sketch and document what he finds. And he shares his information.

Larry Banks, former U.S. Army Corps of Engineers, Fort Worth District, archeologist.

Homer Norris (1929-2018), a commercial artist by profession and a life-time resident of eastern Parker County, in North-Central Texas (Figure 1), in the South Fork and Clear Fork drainages of the

\section{Natural Regions of Texas}

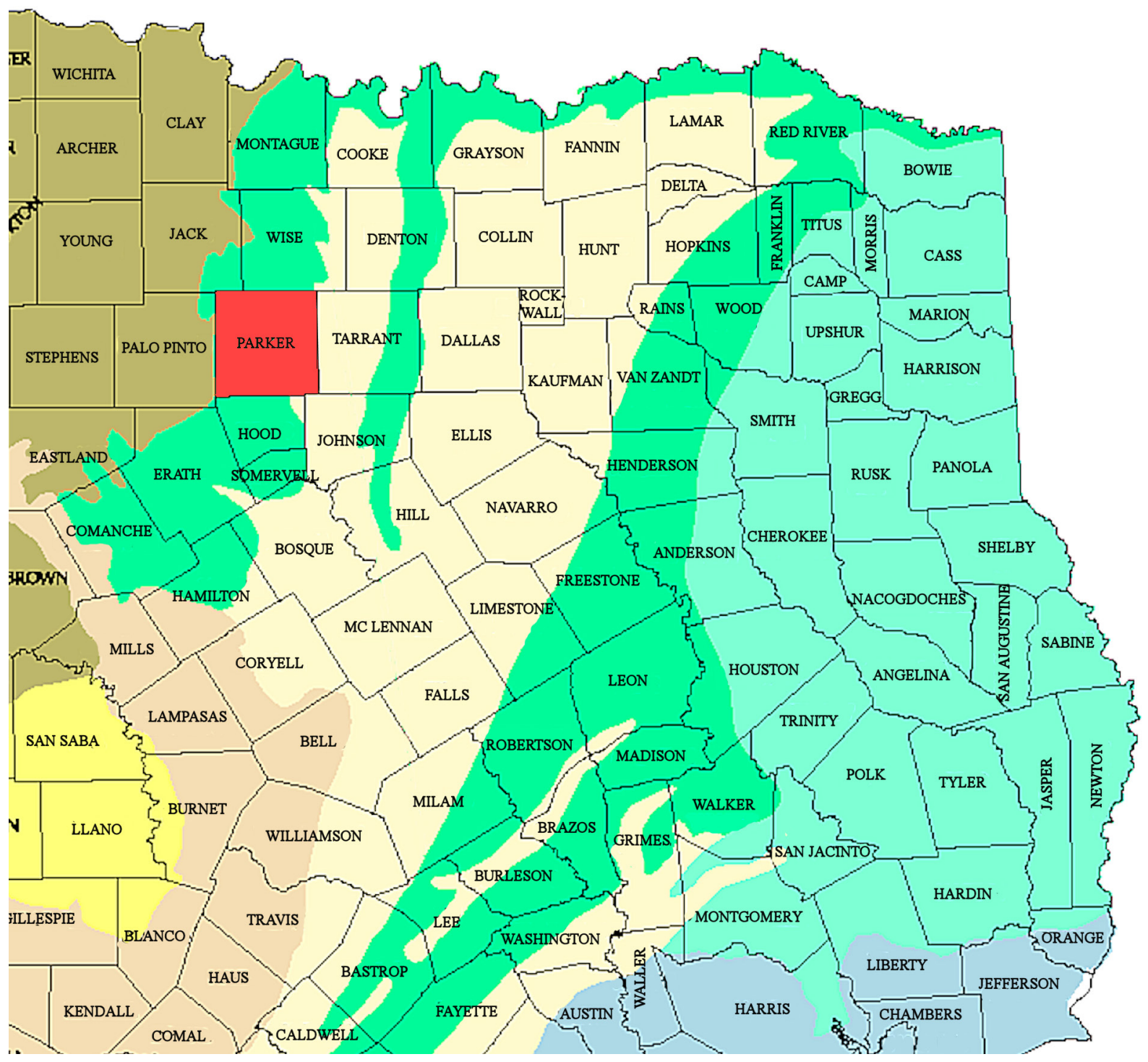

Figure 1. Parker County in North-Central Texas. 


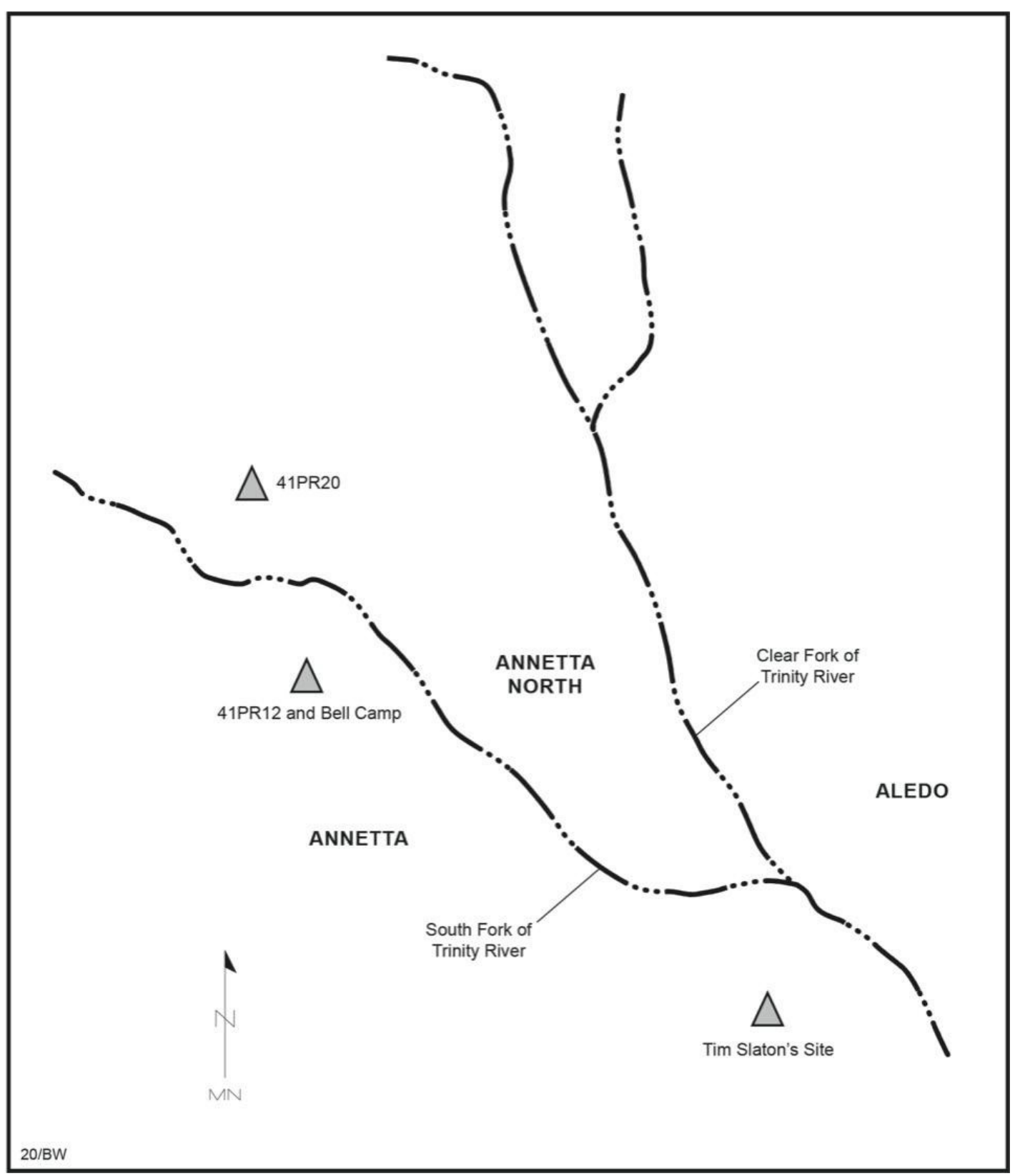

Figure 2. Map of the Annetta-Aledo area of Parker County, Texas, and selected general site locations.

upper Trinity River basin, roamed the landscape from at least 30-50 years ago in search of archeological evidence of Native American use and settlement in the basin (Norris 2006). He took and maintained detailed notes, records, and drawings of the sites he found and the artifacts he recovered, as well as pertinent information on the context of finds, including those noted eroding out of stream cut banks and in stream beds of the South Fork and Clear Fork in the Anetta-Aledo areas of Parker County (Figure 2), about 15 miles west of Fort Worth, an area of about 5 miles on a side. This information, made available by his daughter Lanie Garmon of Aledo, Texas, from his archeological investigations is detailed herein, along with a summary of how his investigations contribute to a fuller understanding of the native history of this region of Texas (see also Todd et al. 2009). 


\section{Environmental and Cultural Setting}

Norris primarily worked in eastern Parker County in the South Fork of the Trinity River basin in areas of the Blackland Prairie and the Western Cross Timbers biotic regions (Diamond et al. 1987). The South Fork merges with the Clear Fork near Aledo, Texas, and the Clear Fork and the West Fork merge in the Fort Worth, Texas, area to form the Trinity River. Each of these streams have extensive Holocene alluvial deposits of clay and sand with the potential to contain buried archeological deposits and a series of buried soils (Abbott 2011). Burgess Creek, a main tributary to the South Fork, flows year-round, but other springs are inactive during summer months.

In modern times, perhaps from ca. 2000 years ago, the Blackland Prairie has tall grasslands of little bluestem and Indiangrass, as well as riparian deciduous trees of elm and sugarberry. The Western Cross Timbers have post oak and blackjack oak deciduous woodlands (Diamond et al. 1987) (Figure 3a-b).

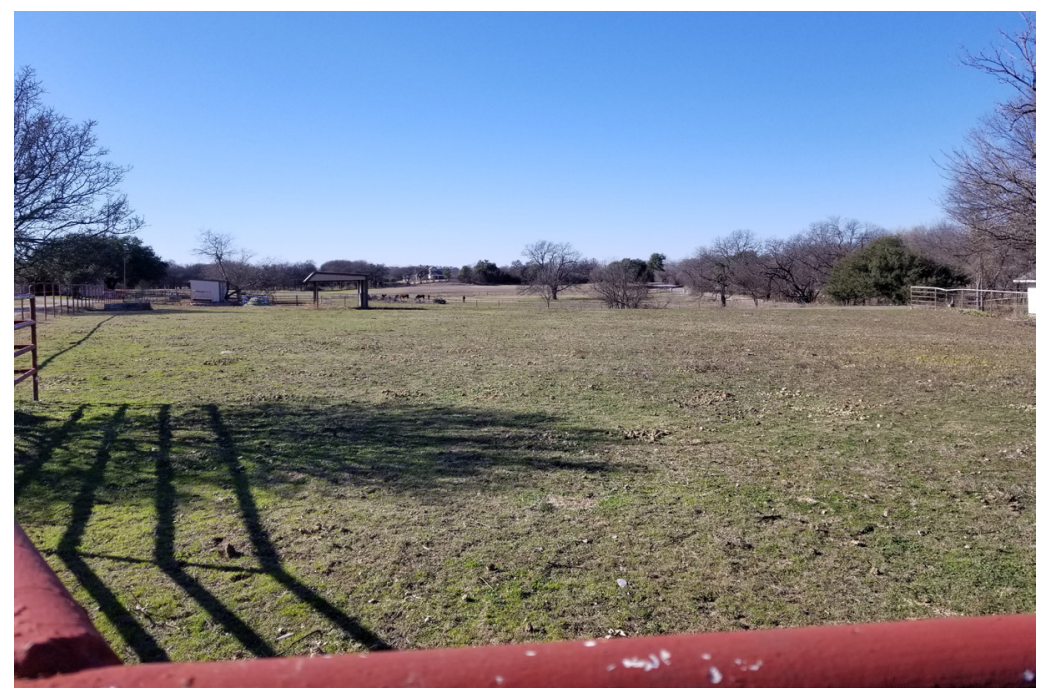

$\mathbf{a}$

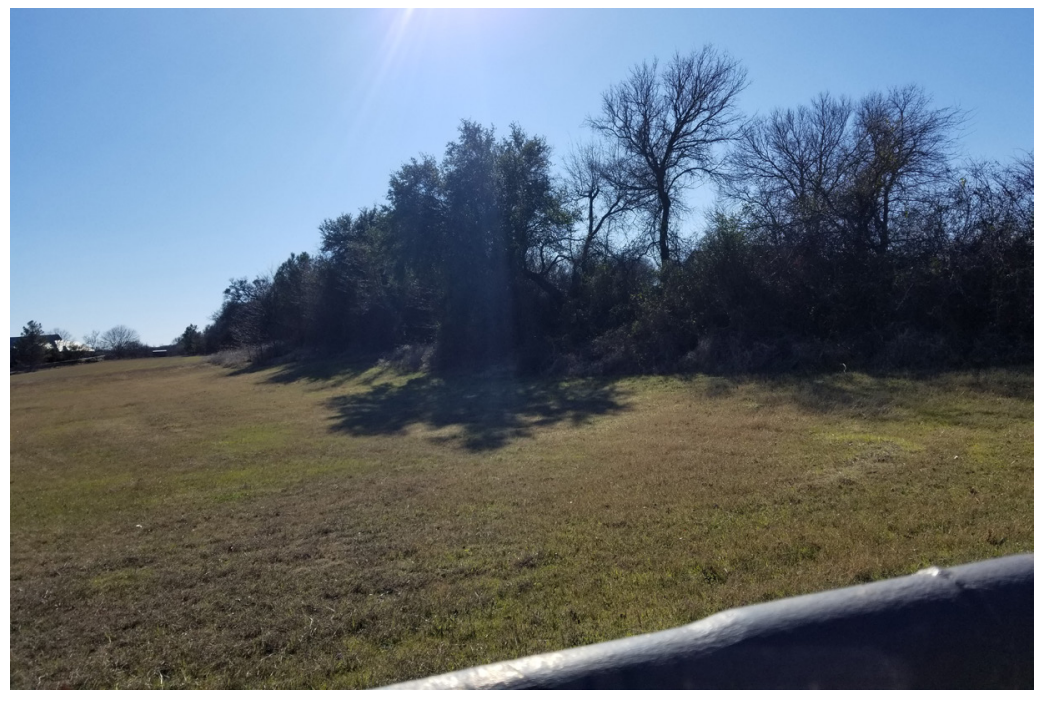

b

Figure 3. Views of the South Fork of the Trinity River landscape: a, pasture and woodlands; b, upland woodlands. Photographs by Lanie Garmon. 
The upland prairie areas have dark clay soils with lush grasses, and there are sandy lands along the edge of the uplands and floodplain settings below; the sand deposits may range from less than $10 \mathrm{~cm}$ thick to more than 1 meter $(\mathrm{m})$ in thickness.

The Parker County area of North-Central Texas has been used and settled by Native Americans since at least 13,500 years ago, if not earlier, beginning in the Paleoindian period (ca. 13,500-10,000 years ago). Hunter-gatherers continued to use the area through the Early (10,000-8,000 years ago), Middle (8,000-5,000 years ago), and Late Archaic periods (5,000-1,250 years ago), and in much of the Late Prehistoric period (ca. 1,250-300 years ago), when the Native Americans made and used arrow points and had access to ceramic vessels (see Thoms 1994:29-39 and Table 6). Farther east in the Trinity River basin, Native American burials found in Dallas County sites dating after ca. A.D. 1100 may have consumed maize in addition to hunting-gathering pursuits (Lintz et al. 2008:19). Detailed summaries of the Native American culture history of the region can be found in Fields et al. (2005), McWilliams et al. (2006) Lintz et al. (2008), and Mauldin and Figueroa (2006). 


\section{Investigated Archeological Sites and Collections}

\section{Red Ochre Burials (41PR12)}

In March 1985, John Norris, the son of Homer, was searching for prehistoric artifacts across a 4-acre area being excavated for gravel in an alluvial terrace landform (860 feet amsl) south of Burgess Creek. He noted the "partial cross-section of a human skull." Burgess Creek flows north into the South Fork of the Trinity River. The heavy equipment had hit the skull of the individual, which was removed to preserve it. The bones were stained red, and there were pieces of red ochre near the skull (Everett 1989). Originally, the burial was resting between ca. 4-6 ft. bs in a sandy terrace deposit, resting at the juncture of the sand and the underlying glauconitic clay B-horizon. Figure 4, taken in December 2019, is looking west at the area of 41PR12, while Figure 5 (also taken in December 2019) shows the area of the site, looking south-southeast at the Bell Camp.

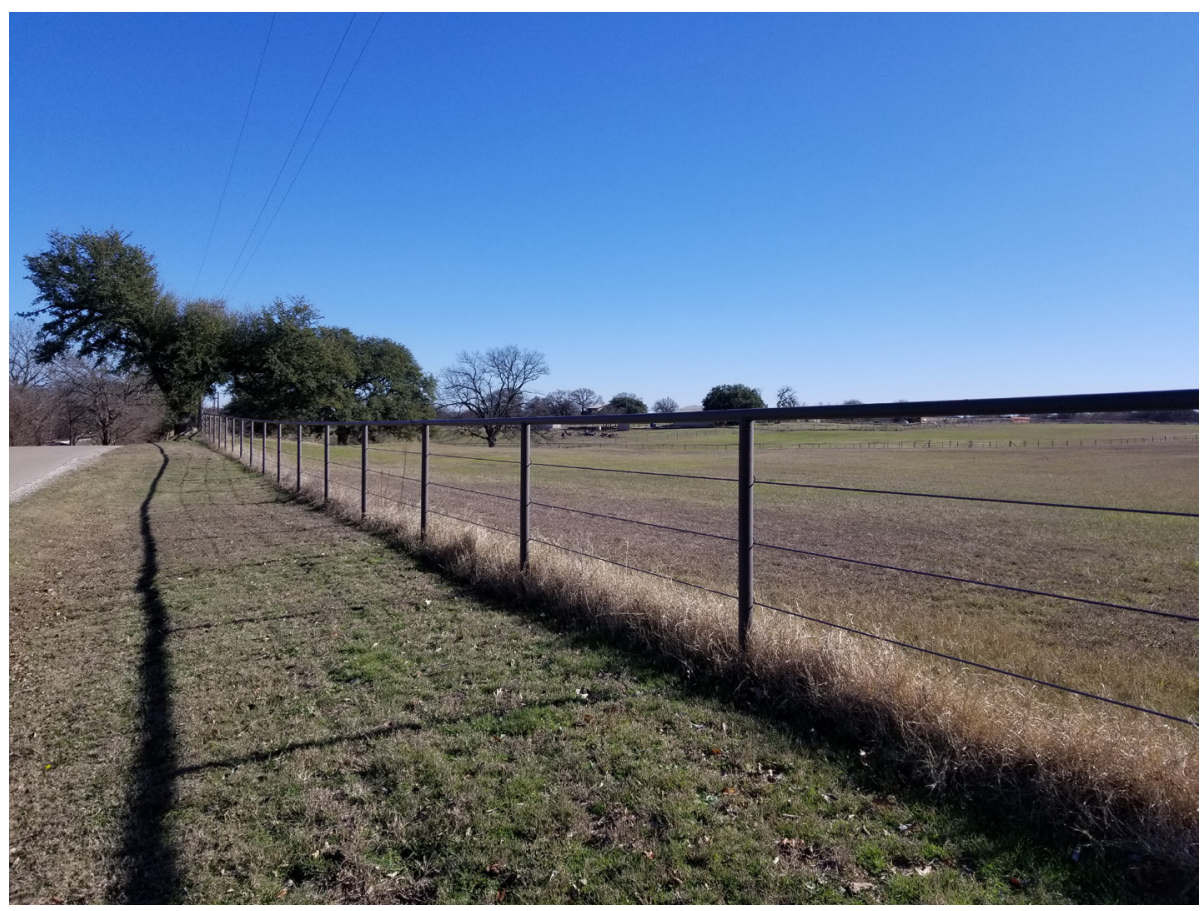

Figure 4. Looking east at the area of the Red Ochre Burials site. Photograph by Lanie Garmon.

On April 1, 1985, assistance was provided by Larry Banks (then of the Fort Worth District of the U. S. Army Corps of Engineers), Pat Mercado-Allinger (Office of the State Archeologist at the Texas Historical Commission), and members of the Tarrant County Archeological Society (TCAS), who excavated the burial area and an adjacent midden deposit (Everett 1990). Burial 1 in Units S20 W2 and S20 W3 was flexed (Figures 6 and 7), with the skull to the northwest, and facing east. It was mainly intact, except for missing portions of the skull, one femur, and the bones from both feet. Burial 2 was a few meters to the east in Unit S19 E2, and although more fragmentary, appeared to have the same orientation. This burial was missing much of the skull, the rib area was poorly preserved, and the leg bones had been pulverized, probably from heavy equipment traffic across the sandy sediments above the burial itself. The bones from both individuals were stained a deep red from red ochre, as was the surrounding soil matrix. It was suggested that Burial 1 was that of an adult female while 


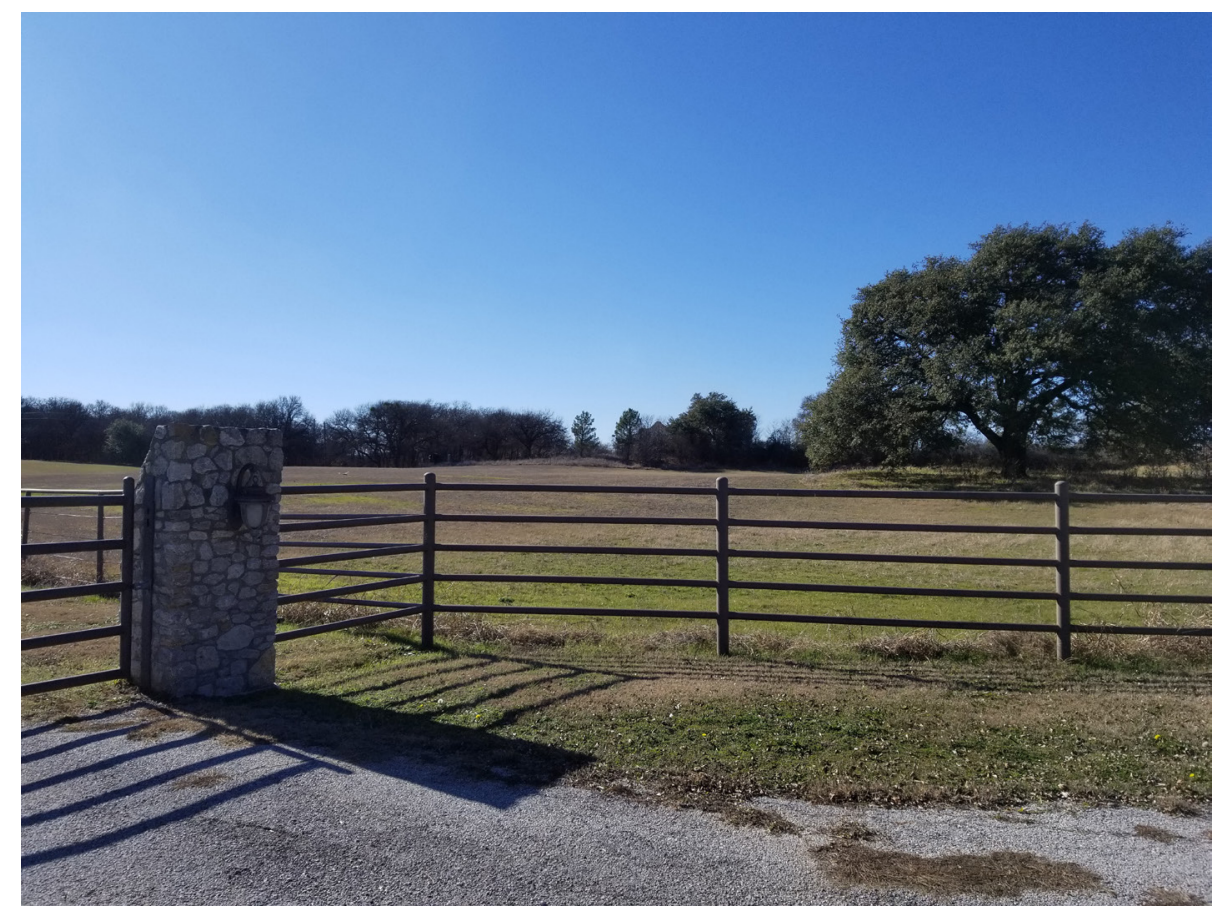

Figure 5. Looking south at Bell Camp and the area of the Red Ochre Burials is to the right past the large tree. Photograph by Lanie Garmon.

Burial 2 was that of a younger male; recent bioarcheological analyses indicate that the burials are adult males (see below).

Four fossil gryphaea shells had been deliberately placed in the burial pit under the spine of Burial 1, and another was recovered in S20 W3; three others were found when the matrix was later removed around the burial block. Some few pieces of a blackened organic material were also present in the burial matrix, and these may be preserved pieces of leather, suggesting that Burial 1 may have been wrapped (Everett 1989), or that the individual may have been wearing a leather bag or pack. In his notes, Norris mentioned that he recovered the "long fang" of an unidentified animal behind the maxillary arch of this burial, and this was sent to the Smithsonian Institution with the human remains and other recovered associated artifacts; apparently this fang did not make it to the Smithsonian Institution with the other artifacts.

No grave goods were present with Burial 2, but two arrow points broken by impact fracture were found in the chest area, facing east, as if the individual had been shot and killed from the front by the arrows. Both arrow points appear to be corner-notched and expanding stem arrow points, probably of the Scallorn type, the first made from a brown/tan chert and the second from a gray chert. The ethnic or cultural affiliation of the aboriginal peoples that made and used the Scallorn arrow points is not known, but it seems evident that the individual represented by Burial 2 was killed with arrow points by another individual that was defending its territory (f. Kelly 1995) in the upper Trinity River basin, probably "triggered by territorial disputes over food resources" (Dockall 1997:16).

A short distance west and northwest of Burial 1, but at the same depth (Figure 8a), was an area of thin midden deposits. Excavations by the TCAS uncovered burned limestone rocks, a burned rock feature, and pieces and flecks of wood charcoal, as well as a few animal bones, chert lithic debris, and 


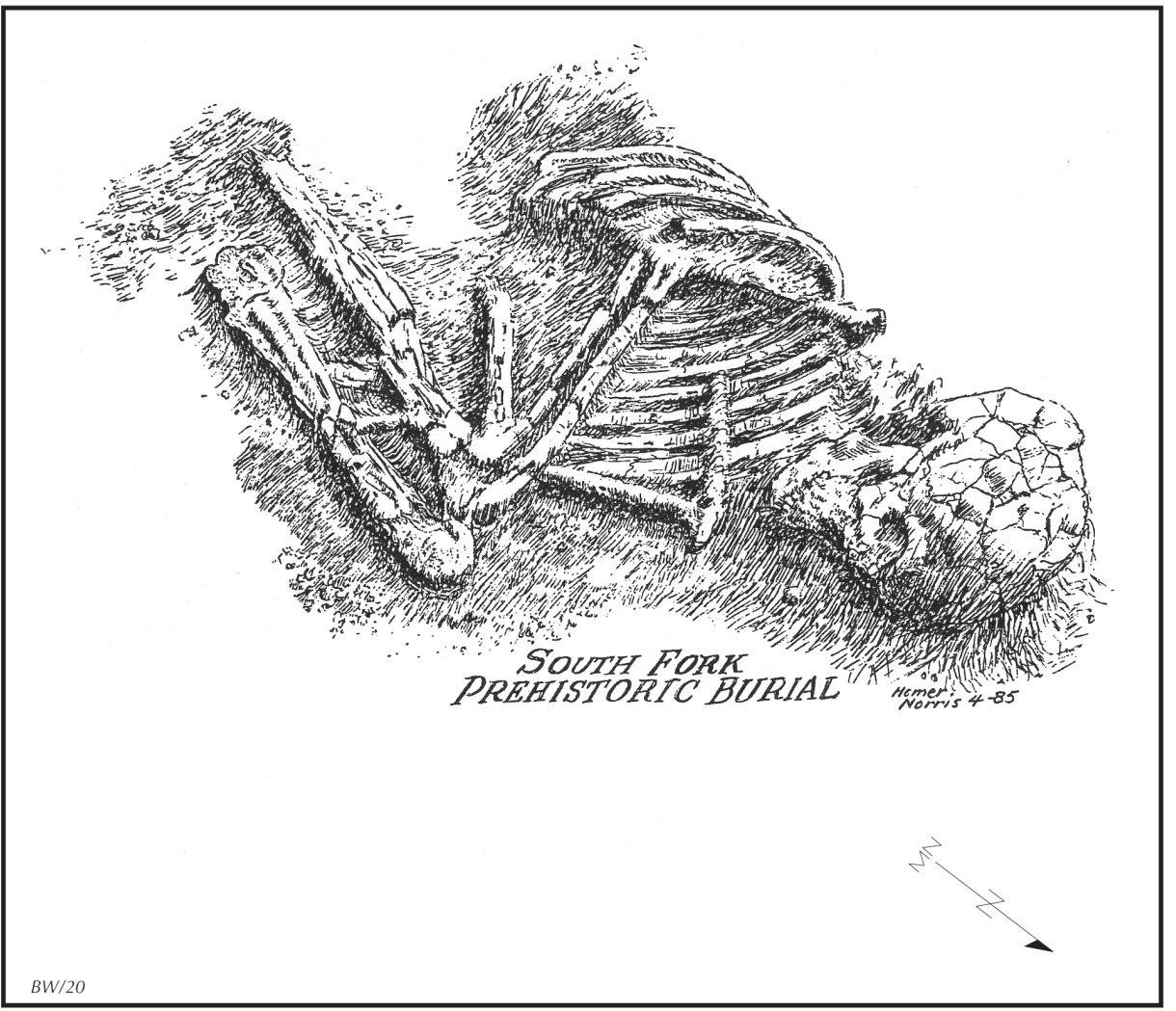

Figure 6. Plan map of Burial 1 at the Red Ochre Burials site. Drawing by Homer Norris.

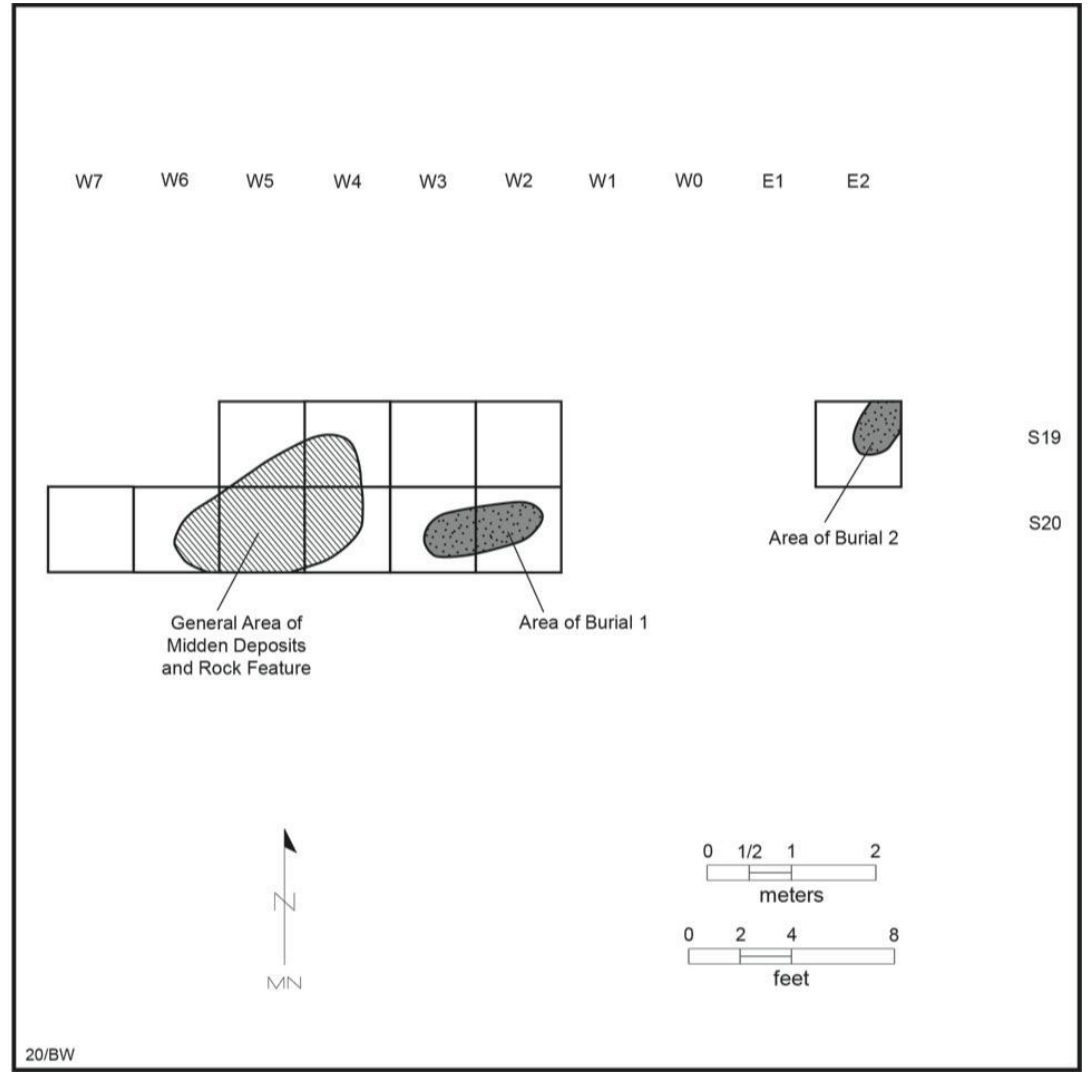

Figure 7. Plan map of excavation units at the Red Ochre Burials site. 


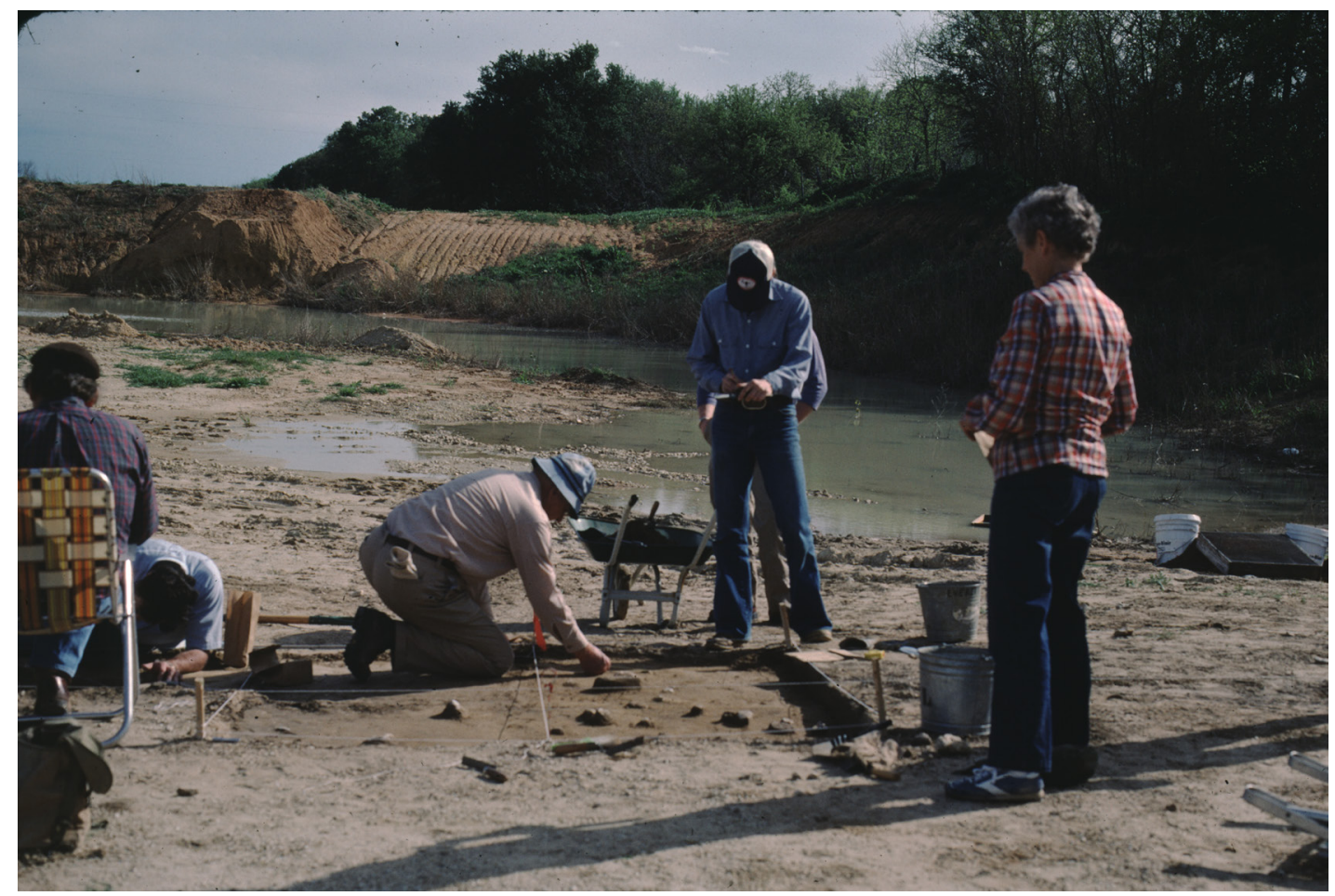

a

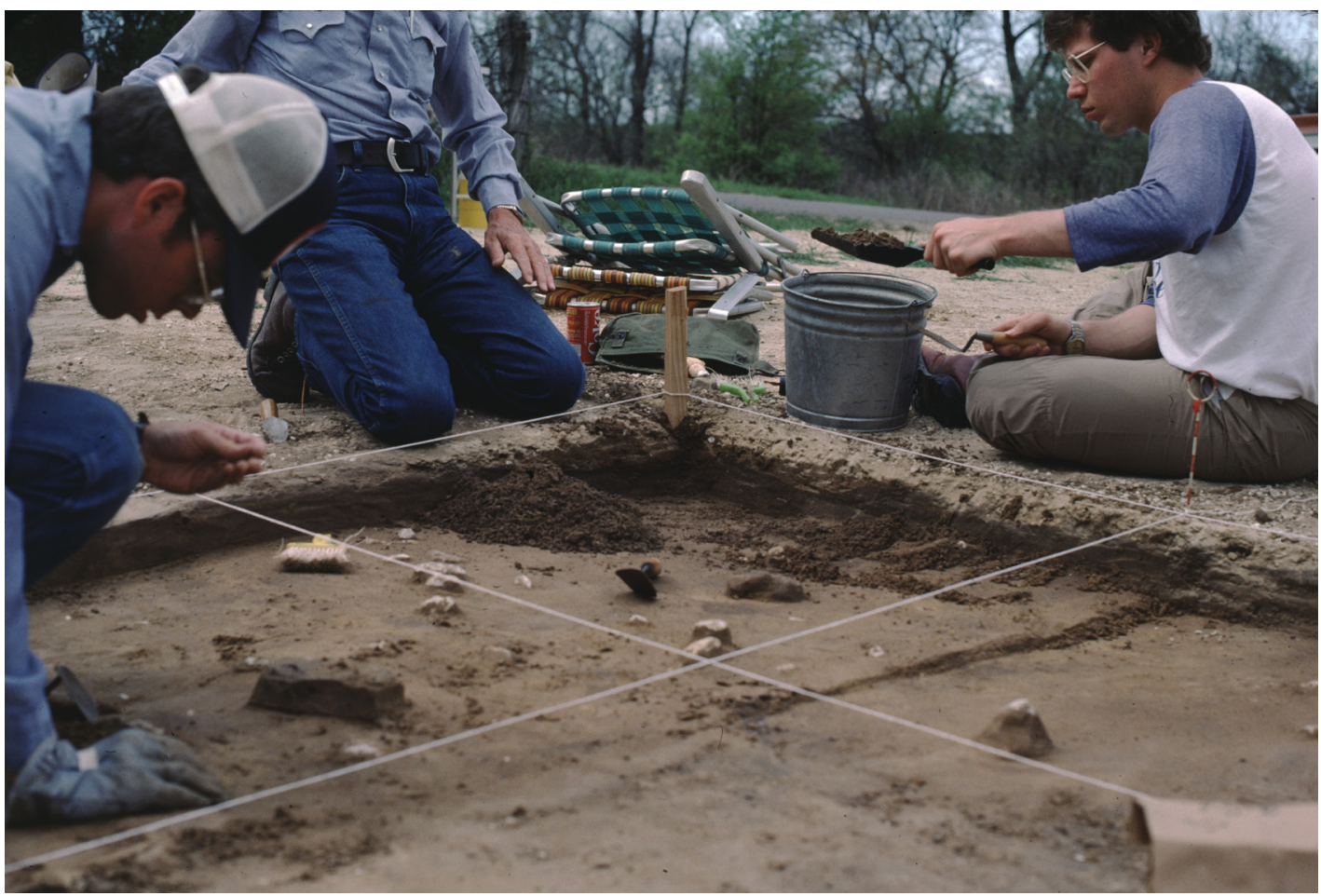

b

Figure 8. Excavations in midden area west and northwest of Burial 1 at the Red Ochre Burials site: a, excavated units with gravel pit in the background; b, view northwest of test units, with thin midden deposit in unit wall; $c$, view of western excavation units; charcoal pedestaled in the background; d, Larry Banks excavating a test unit at the site. Photographs a-c courtesy of the Texas Historical Commission; d, courtesy of James Everett. 


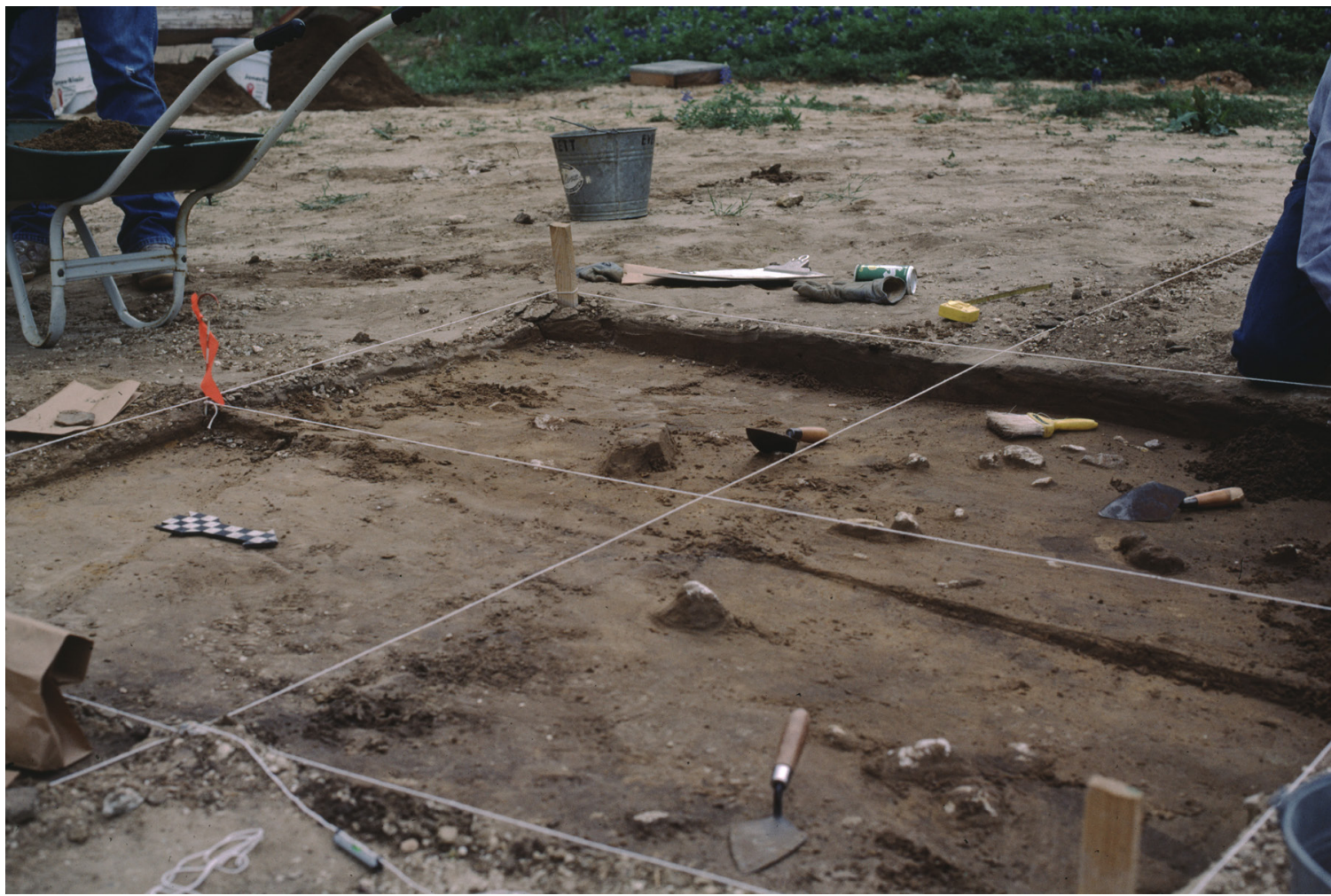

c

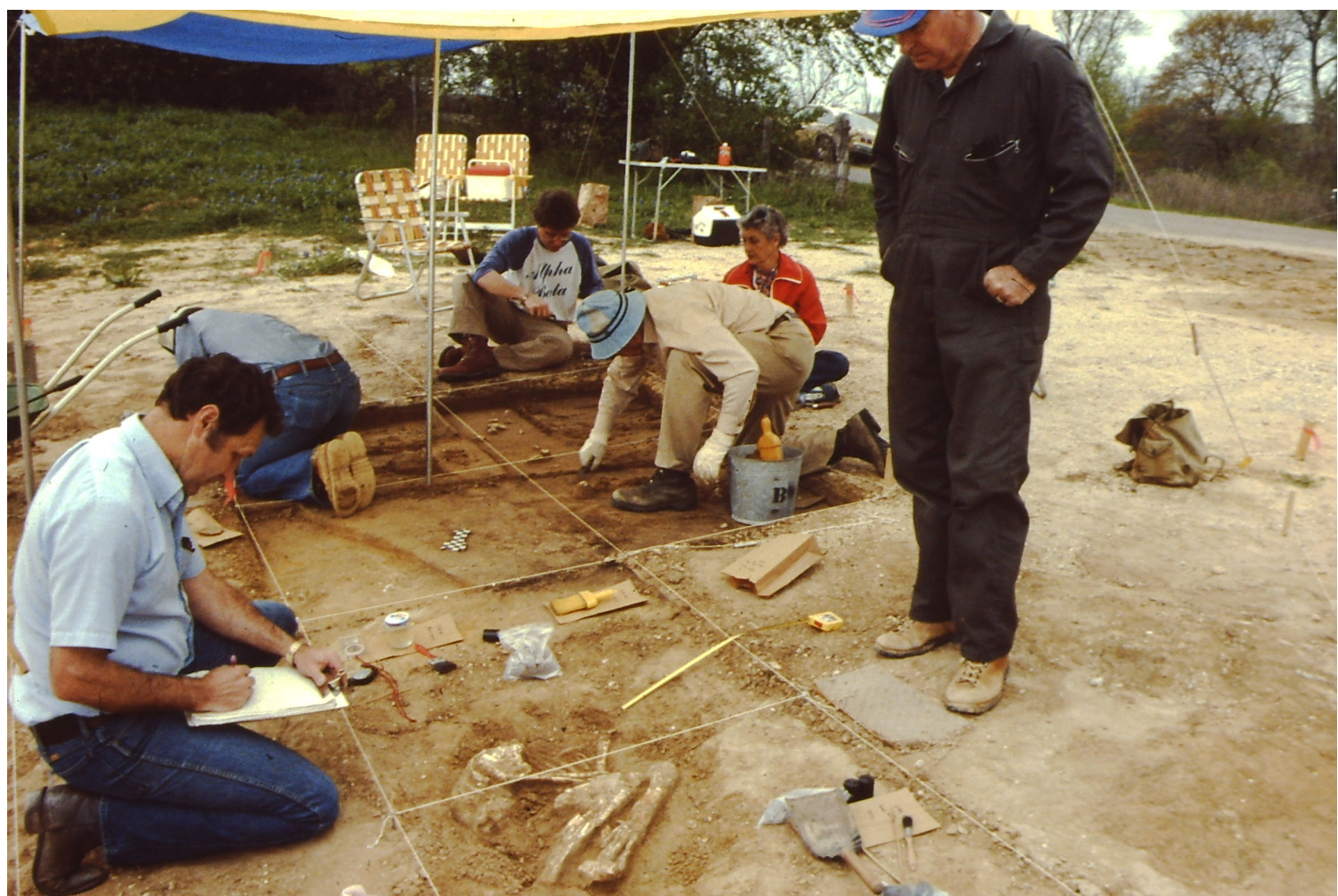

d

Figure 8. (Continued) 
gryphaea fossils (Figure 8b-d; see also Figure 7). Two radiocarbon dates were obtained by the University of Texas Radiocarbon Laboratory in 1986 on charcoal from the midden area near Burial 1. The two uncorrected dates are $980 \pm 120$ B.P. (Tx-5427) and $1070 \pm 450$ B.P. (Tx-5426) (Everett 1989); the large standard deviations are a product of the small sample of the wood charcoal (pre-AMS dating procedures) submitted for dating at the time.

The radiocarbon dates from 41PR12 are calibrated at 1 sigma (68.3 percent probability) and 2 sigma (95.4 percent probability) using INTCal 13 and Calib 7.1 (Reimer et al. 2013; Stuiver et al. 2020).

The age ranges at 2 sigma (95.4 percent) with the highest probabilities are A.D. 855-1266 (0.96 or 96 percent) and A.D. 20-1683 (0.99 or 99 percent) (Figure 9); the large standard deviation of the 1070 \pm 450 B.P. sample is responsible for the extreme range of the calibrated age range. Nevertheless, the median calibrated age ranges for the two dates are A.D. 915 and A.D. 1056, consistent with the known dates of Scallorn arrow points in North-Central Texas during the Late Prehistoric period, from broadly ca. 650/700-1250 years B.P. (see Lohse et al. 2014:273), but more likely in an age range from 900-1250 years ago based on the ages of succeeding arrow point types such as Alba or Perdiz.

The human remains and associated artifacts were sent in 1989 to Dr. Douglas Owsley of the National Museum of Natural History at the Smithsonian Institution in Washington, D.C. for study and analysis.

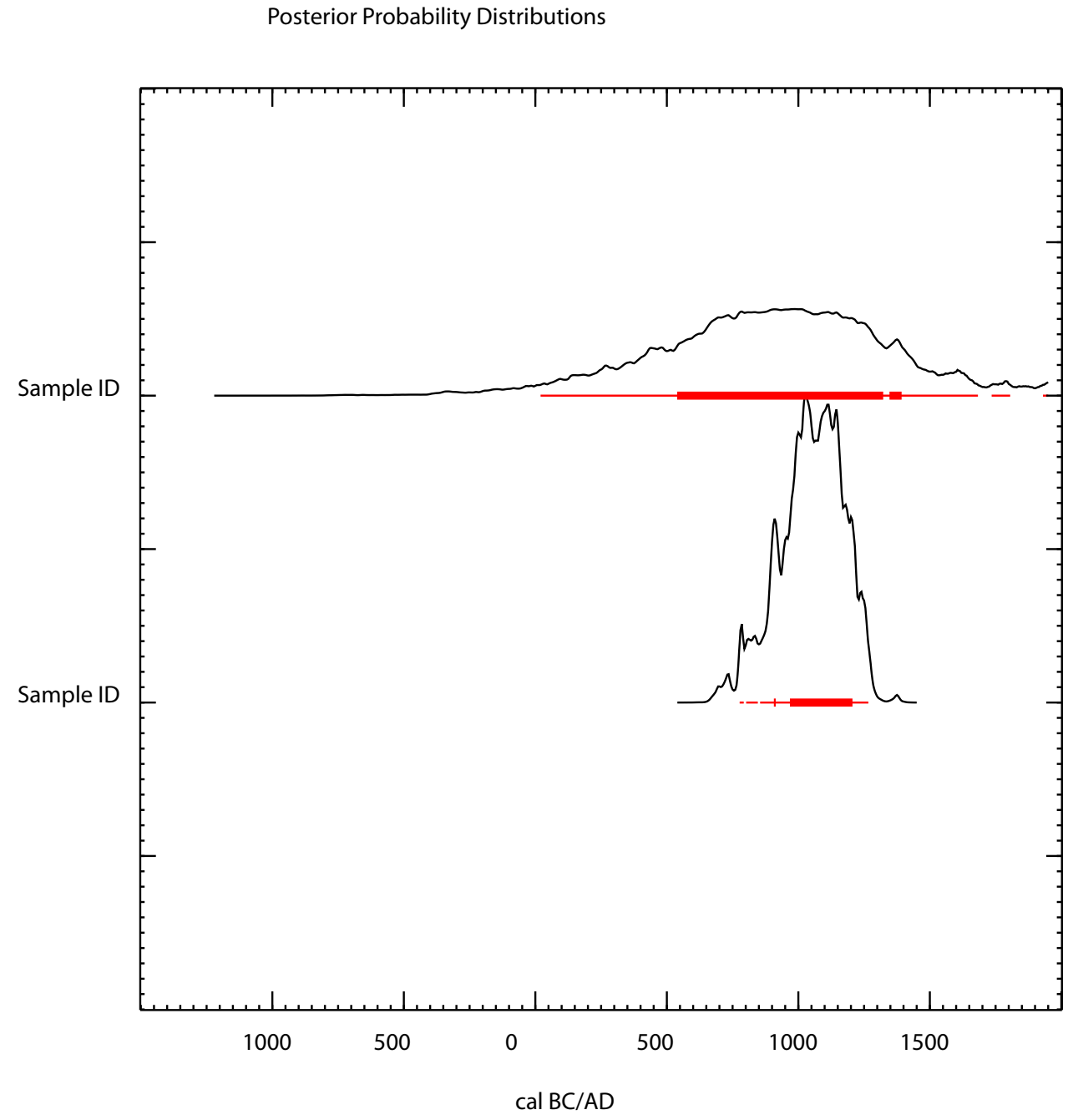

Figure 9. Probability distributions of the two calibrated radiocarbon dates from 41PR12. 


\section{Ancient Conflict and Ritual in North Central Texas}

\section{Karin S. Bruwelheide and Douglas W. Owsley, National Museum of Natural History, Smithsonian Institution}

\section{Background}

In July 1985, Homer Norris reported the discovery of two partial human skeletons identified as "South Fork Woman" and "South Fork Man," to a meeting of the Tarrant County Archeological Society (TCAS). These remains were inadvertently found after being crushed and partially scraped away by gravel-digging equipment. A follow-up report by James Everett (1989) provided additional information about the discovery of the first burial in a gravel pit by Homer's 16 year-old-son, John. The quarry is located west of Annetta in Parker County on a terrace south of Burgess Creek, which flows north into the South Fork of the Trinity River. This area was a known collection locality for prehistoric artifacts.

Heavy equipment had exposed and crushed the first burial, and it was clear that further damage was imminent. Mr. Norris and his son took action to protect the remains. They contacted Larry Banks, retired senior archeologist of the U.S. Army Corps of Engineers, Fort Worth District, who in turn contacted the TCAS for assistance with the archeological recovery. Members of the TCAS, Mr. Norris, Larry Banks, and Pat Mercado-Allinger of the Office of the State Archeologist mapped and removed in a bloc lift the remaining portion of the first skeleton on March 31, 1985. TCAS members Jeff and Joan Ball then carefully removed the fragile bones of Burial 1 from the hard matrix in a protected setting.

On May $10^{\text {th }}, 1985$, Homer Norris returned to the discovery location and slightly upslope, four meters east and one meter north from Burial 1, found teeth, pieces of a second skull, and nodules of red ochre. Members of the TCAS mapped and excavated this highly disturbed burial on May 12-13, 1985.

The TCAS investigation concluded that two tightly flexed skeletons, recognized as Burials 1 and 2, were present. The bodies had been placed on their left sides with the skull of Burial 1 directed toward the northwest and facing east. Burial 2 showed greater disturbance but appeared to have had the same orientation. Two conventional radiocarbon dates $(980 \pm 120$ B.P. and $1070 \pm 450$ B.P.) were obtained from small samples of hearth and midden residue found near the burials. Large deviations $( \pm)$ with the dates are attributed to the small amount of sample material tested (Everett 1989), but indicate an antiquity of about 1000 years B.P.

The two skeletons are highly fragmented and incomplete. Mr. Norris had placed a water-diluted solution of Elmer's glue on the compressed partial cranium and mandible of Burial 1. The postcranial skeleton was treated with a consolidate of PVC by Banks and Mercado-Allinger to help stabilize the highly degraded bone. Burial 2 remains show greater postmortem fragmentation and disturbance but were not treated with preservative. The fragments of each skeleton were carefully packaged in tinfoil envelopes and plastic bags for future analysis and labeled as to individual and general anatomy (e.g., arm bone).

At the time of the recovery TCAS members clearly stated their interest in having these remains examined by an osteologist. Although unsuccessful at the time, decades later this study fulfills this request. Bone and tooth inventories document the representation of each individual and more detailed assessments of age, sex, and evidence of injuries or cause of death are presented. Observations are limited due to poor preservation, particularly features of bone pathology. Still, the evidence provided by these human remains is significant, as they offer rare, but direct, insight into the life histories of the prehistoric people of Texas. When combined with other forms of mortuary data, the ritual behaviors, material culture, and social interactions of the past are revealed. 


\section{Burial 1}

Remains recovered from Burial 1 represent a small male with an estimated age of 30 to 36 years. This determination was based on complete eruption of the dentition, moderate to severe levels of tooth wear, little alveolar bone resorption, the absence of degenerative (arthritic) changes on observed joint surfaces, and the presence of minor cortical striations on long bone diaphyses.

The cranium and mandible are fragmented, but the skull's left side is intact due to the presence of dry, hard soil supporting the left cranial vault. The right side is compressed and was nearly graded away by the heavy machinery that exposed the skeleton. The remaining portion of the cranium is represented by a partial frontal bone, complete left parietal, partial right parietal, partial occipital, complete left temporal, complete left malar, partial left and right maxillae, and a partial mandible.

In the field, this individual was identified as a female. However, features are more indicative of a male sex, including a square chin with a prominent mental tubercle, slight gonial flaring on the preserved left side mandible, and a relatively acute gonial angle of the mandible's ascending ramus. The cranium is comparatively small, but the left malar and fronto-malar process are somewhat robust, and the left mastoid process is moderately large. The superior orbital margin is eroded and cannot be evaluated. The brow ridge does not appear to have been developed, but the bone in this area is fragmented and slightly compressed.

The outer cranial surface is smooth, suggesting a young adult age. Small sections of the cranial sutures are visible, but the degree of suture closure cannot be fully evaluated. The sagittal suture appears to have been open externally. Teeth from the left mandible and right maxilla that can be observed show moderately advanced crown wear, a pattern consistent with the highly abrasive diet characteristic of the region in prehistoric times.

The postcranial bones are so fragmented that few features can be used for further confirmation of sex. Articulation of some femur fragments indicate a small individual. The left femur mid-shaft diameter has a maximum measurement of $27 \mathrm{~mm}$. Other postcranial elements include a highly fragmented left humerus, ulna, radius, tibia, and fibula. Also present are small pieces of thoracic and lumbar vertebrae, several left and right ribs, the calcanei, tali, and both patellae. Based on the presence of a right patella, calcaneus, and talus, some leg bone fragments likely represent small portions of the right femur, tibia, and fibula, which are largely missing. These limb bones are so broken, however, that identification as to side cannot be made with confidence.

At least four lumbar vertebrae are present based on partial vertebral arches. None of the represented articular facets show evidence of arthritic changes. A few long bone joint surfaces are present (the left radial head, proximal ulna, and distal humerus) and show normal morphology with no degenerative changes. The hand bones are small and gracile with slight development of the ventral marginal ridges on the phalanges.

The overall size of this individual is small, and it is easy to understand why this individual was initially identified as a female. Nevertheless, mandibular morphology is diagnostic of a male sex. This individual's physical size is comparable to the individual recovered from Burial 2.

Dental observations are limited because several teeth remain embedded in soil and cannot be removed without further breakage. Some teeth are loose, mostly from the right side, and portions of their alveolar sockets are discernable. Represented visible teeth include the right maxillary incisors, canine, premolars, and first molar, and the left maxillary central incisor. Also present are the right mandibular 
incisors, premolars and the left mandibular incisors, premolars, and molars. The left maxillary arcade was displaced and remains embedded under the left mandibular teeth, such that observations cannot be made.

No teeth have carious lesions and only tiny flecks of dental calculus are present. A diet that included abrasive components caused moderate to severe crown attrition. The degree of wear is slightly more than observed for Burial 2, suggesting that this male was a few years older. Despite relatively advanced tooth wear, alveolar resorption is minimal.

A reddish discoloration indicating the application of a mineral pigment on the face at the time of death is evident on the left side of the cranium in the region of the pterion, the left malar and zygomatic arch, and on the inferior left horizontal ramus of the mandible. Likewise, the entire diaphysis (shaft) of the left ulna has a faint reddish discoloration, as do fragments of the left humerus, left carpals, and phalanges. This side of the body was down; the right side cannot be evaluated because it had been scraped away.

Four fossil oyster shells of the genus Gryphaea were found under the spinal column of Burial 1 (Figure 10a-b). Another one was recovered from the underlying matrix in approximately the same

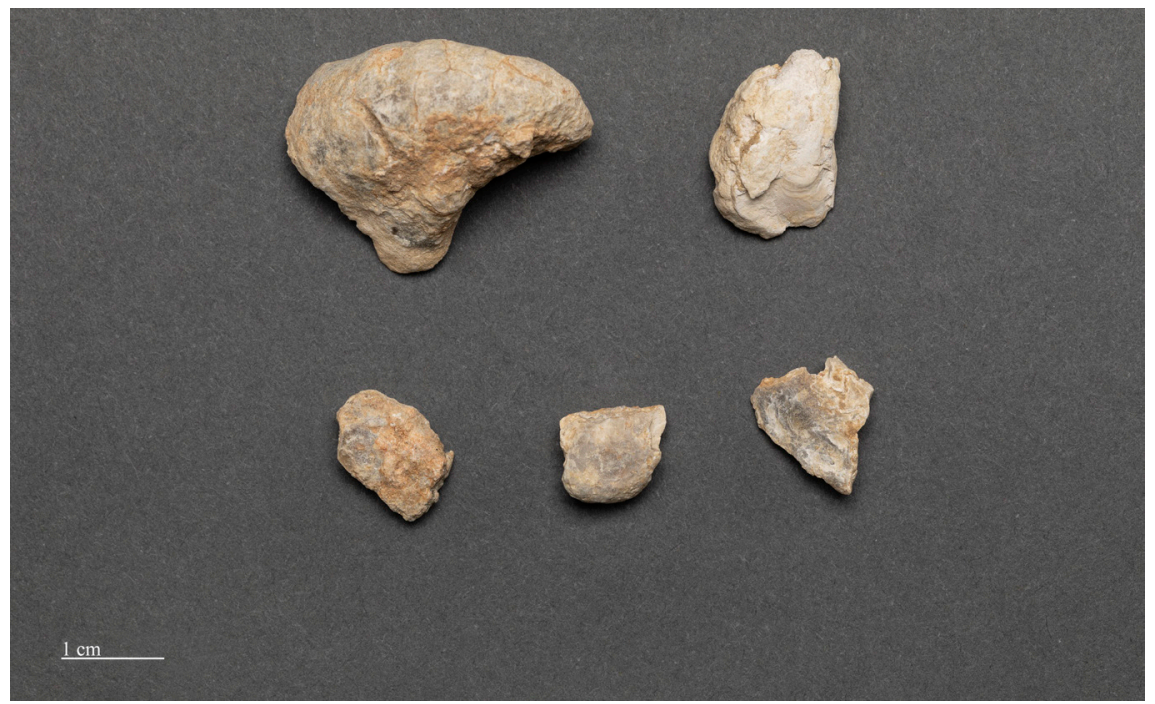

a

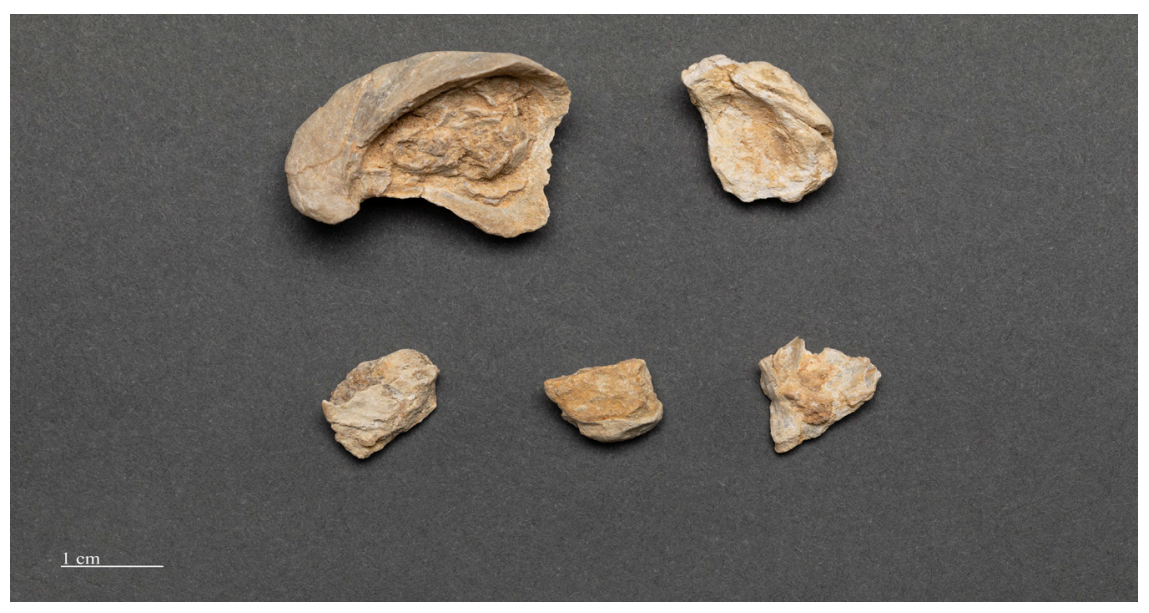

b

Figure 10a-b. Fossil oyster shell fragments of the genus Gryphaea found in the surrounding matrix and under the spinal column of Burial 1. 
location as the first four after lifting the burial block. Three additional incomplete shells were recovered from the block of matrix during the more controlled in-house excavation, yielding a total of eight pieces of shell. Several light-colored lithic flakes and one black chert flake were also found and mapped with this individual (Everett 1989).

\section{Burial 2}

This skeleton is more fragmented than Burial 1 from greater construction disturbance. Despite relatively complete representation of the teeth, with a few remaining in their partial sockets, the cranium and mandible are highly fragmented and only some pieces were recovered. The left temporomandibular joint and petrous are identifiable; the whole right-side cranium is missing.

The postcranial skeleton is also very incomplete. Tiny fragments of both scapulae are present along with a right clavicle fragment. One partial right rib in the three through 10 anatomical range is identified, as are incomplete first and second vertebrae. From an overall perspective, bones from the left side of the skeleton are more often represented, and right-side elements are generally missing. Incomplete left side long bones are present, but no fragments of right-side long bones were recovered. Asymmetrical representation suggests the left side was down, as was the case for Burial 1, and that the right side was removed by machinery.

These remains represent a male aged 25 to 34 years, as suggested by less advanced tooth wear relative to Burial 1. The inner table of the cranium has slight meningeal artery impressions, also an observation more common in younger adults. The identification of sex is based on the size of the teeth, thickness of fragments representing the mandibular body, moderately thick cranial bone fragments, and bone size relative to Burial 1.

The maxillary dentition includes the right incisors, canine, premolars, and first through third molars, along with the left central incisor, canine, premolars, and second and third molars. Small cavities are present on the interproximal surfaces of all three right molars. The roots of the first and second molars were also affected by decay.

The mandibular dentition includes the right canine, first premolar, and first through third molars, and the left canine, premolars, and first through third molars. No mandibular teeth show decay, but tiny flecks of dental calculus are present.

Irregular and remodeled sclerotic bone is present on fragments of the left ulna and radius. Left tibia diaphysis fragments also have surface irregularities due to sclerotic bone. Poor preservation of the outer cortex greatly limits observations of this pathology, but its presence suggests a systemic, chronic, inflammation prior to death.

Direct evidence for a violent death of Burial 2 is in the form of two Scallorn arrow points found in the chest region; one was excavated in situ within the rib cage (Figures 11a-b). The smaller point is serrated and was made using a striated brown/tan chert. It has a stem width of $5.8 \mathrm{~mm}$, a thickness of 2.3 $\mathrm{mm}$, and a recovered length of $20.9 \mathrm{~mm}$. The original length was approximately $23 \mathrm{~mm}$. The tip and both barbs of this point were broken at impact with the body. One barb fractured when part of the surface of the blade spalled off.

A second larger point made of gray chert was found $20 \mathrm{~cm}$ from the first, also under a layer of rib bone fragments (see Figures 11a-b). The distal third of the blade had snapped off along a transverse 


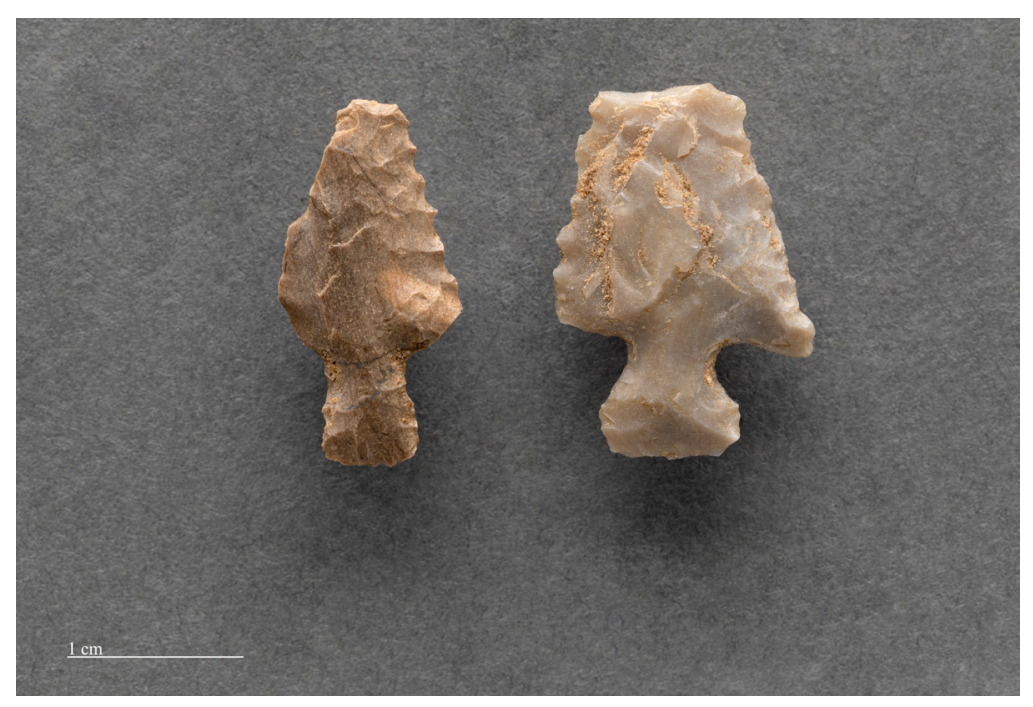

$\mathbf{a}$

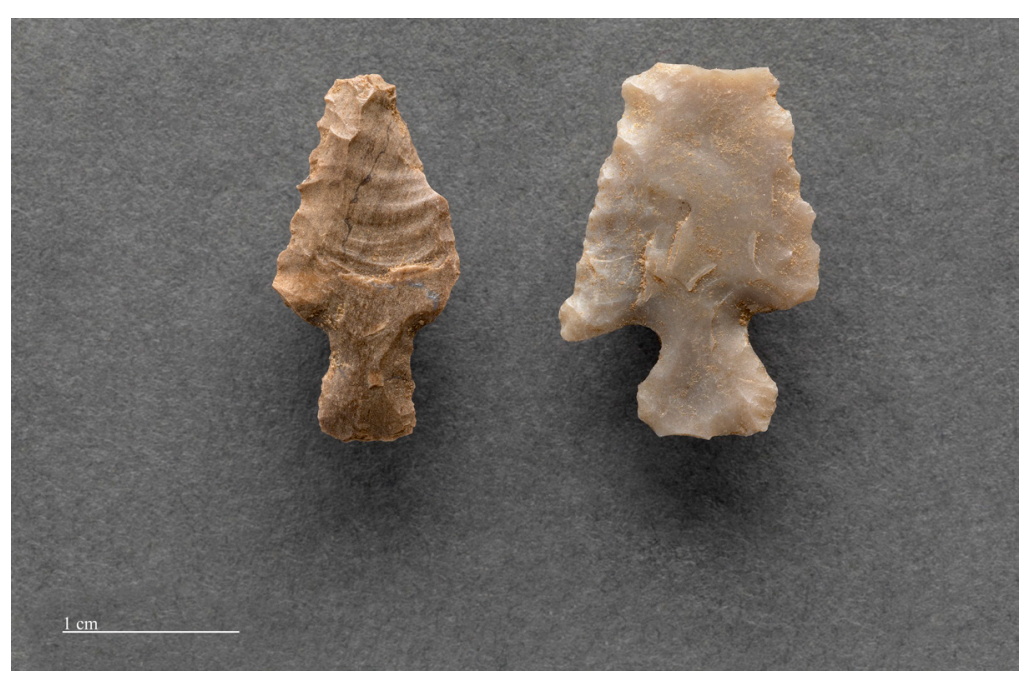

b

Figure 11a-b. Both sides of broken projectile points found in the chest region of Burial 2.

fracture and a barb is also missing. The stem width is $8.0 \mathrm{~mm}$, the thickness is $3.5 \mathrm{~mm}$, and the represented length is $21.3 \mathrm{~mm}$, with an estimated total length of $27 \mathrm{~mm}$.

According to Everett (1989), the bones of Burial 2 were stained red on both sides when observed in the field, but this color is now not easily discernable. As was the case for Burial 1, a red pigment had been applied to the body, a postmortem treatment that with decomposition settled onto and stained the bones. Everett (1989) mentions the recovery of "red ochre pebbles and chunks" in both burial pits. Some of these pieces in Burial 2 may have originally been carried in a pouch that was buried with the body.

Microscopic examinations and assessments of color and hardness identified one piece in Burial 2 as soft hematite, an iron oxide $\left(\mathrm{Fe}_{2} \mathrm{O}_{3}\right)$ with a deep red color. This piece of red ocher is the largest in the assemblage; it measures $35 \times 28 \times 18 \mathrm{~mm}$ in length, width, and thickness and weighs about 25 grams. Also present are 12 small pieces of goethite $(\mathrm{FeO}(\mathrm{OH})$, a denser and heavier hydrated form of iron oxide. 
These pieces are harder, and on a ceramic streak plate produce an earthy brown color (Figure 12). The nodular piece in the center of the image with the botryoidal (bubbly-looking) shape weighs 10 grams and measures $23 \times 15 \times 13.5 \mathrm{~mm}$ in length, width, and thickness. Also found with the remains are five small pieces of slightly reddish sandstone with the grains held together by an iron oxide cement.

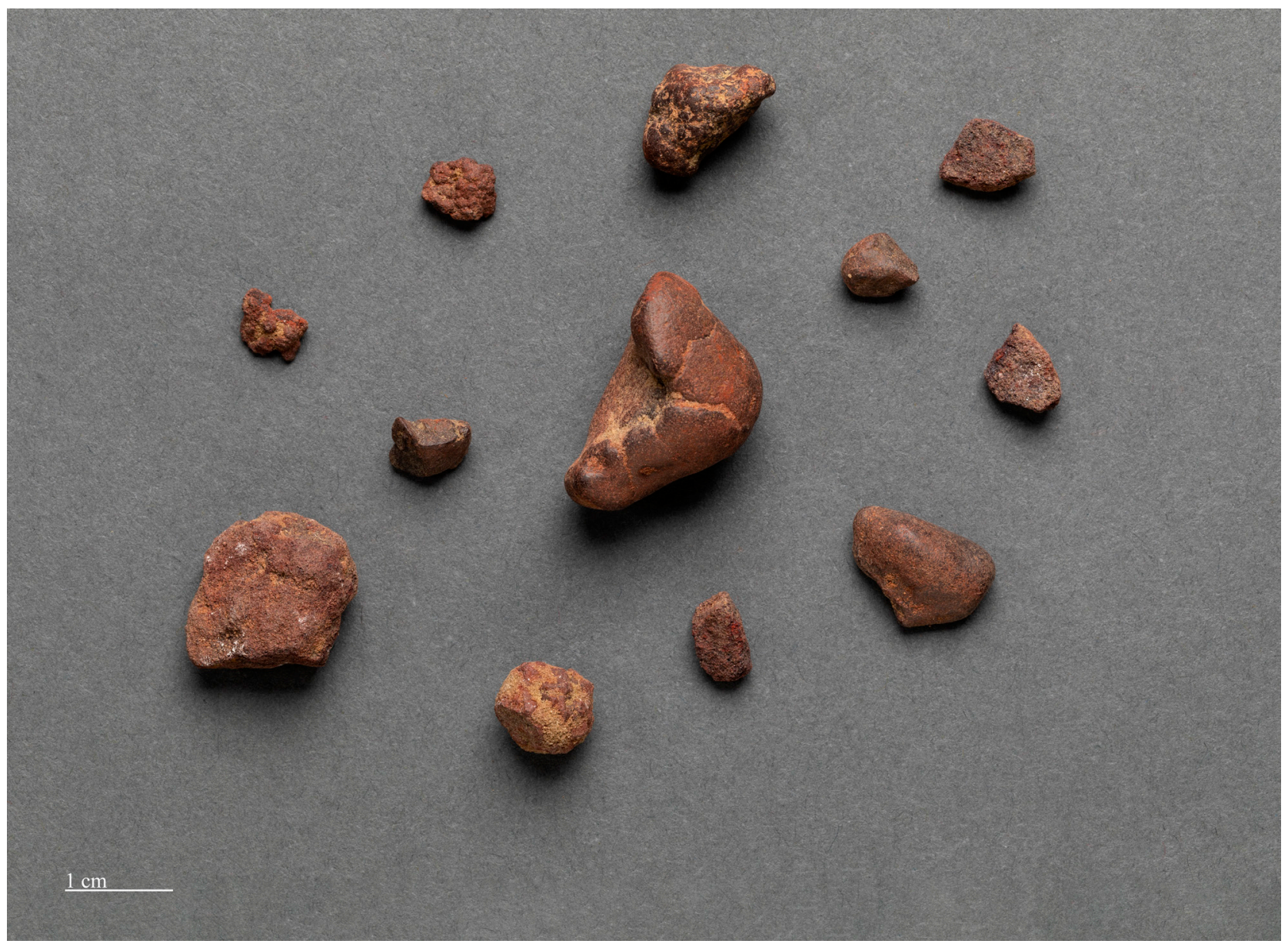

\section{Figure 12. Pebbles and nodules of goethite, a hydrated form of iron oxide that can be used as a pigment (brown ochre).}

\section{Discussion}

Perttula's (2001) synthesis of South and Central Texas mortuary practices considers burial treatment, grave goods, and the incidence of violence as defining characteristics that can be used in the comparison of burials and cemeteries. He found a wide diversity of mortuary practices, but also commonalities that can reflect the formation of populations and territories, group mobility, conflict, and change through time.

Flexed burial positioning, ochre pigments on bones and in burials, the presence of shells and lithics as grave goods, and the occurrence of Scallorn and other points with burials, including those embedded in remains, are among key mortuary attributes. The flexed body positions of Burials 1 and 2 reflect intentional, ritualized, treatment of the dead that has been reported in multiple Texas sites. With exceptions, most cemeteries in the South Texas and Central Texas regions show this form of burial (Perttula 2001). Red pigment found on bones has been documented in Late Archaic and Late Prehistoric burials in Texas, and is common in some areas. Its presence reflects a ritual function rather than a 
utilitarian one. The bones from Burials 1 and 2 in this study show red staining, and three types of red and brown minerals were found in the graves. Their presence suggests preparation of these bodies for burial, although the meaning and significance of this treatment remains unknown.

The fossil shells and lithics with Burial 1 may have had ritual or utilitarian functions. Marine and freshwater shells are variably found in prehistoric Texas burials and a diversity in their occurrence is noted regionally. Their presence as grave goods, along with the lithics “...further highlights the existence of different, but contemporaneous, mortuary traditions within Central and South Texas" (Perttula 2001:62).

The Scallorn points recovered from the ribs of Burial 2 indicate a violent death and are examples of prehistoric technology. Scallorn and Scallorn-like arrow points have been reported for this burial's time period (circa 1000 B.P.) throughout large parts of Texas (Perttula 2001) and more widely across the Southern Great Plains (Brooks 1989; Hofman and Brooks 1989). Several burials referenced in Perttula's (2001:52) study have skeletons pierced with Scallorn points. "Conflicts between groups during the early part of the Late Prehistoric period (ca 1200 to 700 years ago) were widespread in the Central Texas sub-region". Evidence for violence is clustered along river valleys, suggesting these conflicts arose from competition for resources. The presence of two Scallorn points in the ribs of the Burial 2 male records an episode of violence at this site. Documenting this occurrence, even in a single individual, helps define zones of conflict, changes in settlement, and participants in violence.

Studies of skeletal remains provide details about a person's life, and the social and environmental interactions of their community (Owsley 1989). Combined with other analyses, skeletal data can reveal change in these factors through time and among groups.

\section{Conclusions}

Skeletal remains recovered from two burials disturbed by a quarry operation at 41PR 12 are described. Poor preservation limits interpretation, but it is possible to determine their sex, age, and observations relating to health. Both individuals were relatively young males, rather than a male and female as initially reported. Individual 2 died as a result of violence from two arrow wounds to the chest. The data collected also contribute information on mortuary practices in North Central Texas.

\section{Acknowledgments}

Homer Norris, James Everett, Larry Banks, Pat Mercado-Allinger, and the Tarrant County Archeological Society carefully mapped, excavated, and documented these disturbed burials. Avocational and professional archeologists worked together to salvage these remains, which otherwise would have gone unrecorded. We gratefully acknowledge their efforts to ensure that these remains were documented by skeletal biologists. Tim Perttula provided editorial guidance and facilitated publication of this report. Timothy Rose of the National Museum of Natural History (NMNH) Department of Mineral Sciences identified the "red ocher" nodules and David Bohaska of the NMNH Department of Paleobiology provided information on the fossil shells. Interns Lily Haeberle and Kasey Steffenhagan helped with the osteological examination. The artifacts were photographed by Kate Sherwood, NMNH Office of Photo Services and Media.

\section{Use of Red Ochre in Native American Burial Rites in Texas}

As early as Paleolithic times in Europe, the Near East, and Africa, more than 200,000 years ago (Roebroeks et al. 2012; Roper 1992), and from ca. 13,000 years old at the Anzick site in Montana 
(Becerra-Valdivia et al. 2018) to as late as Late Prehistoric and Early Historic times in much of the Americas (Owsley and Jantz 2014), red ochre residues are found in burial contexts, usually with masses of red ochre as a funerary offering covering and staining the bodies of the dead as well as staining accompanying funerary offerings. Red ochre may have symbolized life and death in communities. The red ochre was probably applied to a corpse or their clothes as both a preservative as well as a specific burial ritual, where the red color had an important ritual significance. In some cases, deceased individuals would have had a red ochre-based paint applied to bodies as a burial ritual (Wreschner 1980)

Ochre is a naturally occurring iron oxide pigment found in much of the Gulf Coastal Plain of Texas, particularly red ochre. This mineral is comprised primarily of iron oxide $\left(\mathrm{Fe}_{2} \mathrm{O}_{3}\right)$, and it occurs naturally in Parker County soils. Red ochre pigment is thought to have played an important role in the religious cosmology of Native American inhabitants, including those living in what is now Texas, and the use of red ochre may well have been dictated by the personal identity and social position of the deceased in hunter-gatherer groups (cf. Carr 1995:Table VI).

Red ochre burials are present in a number of different regions in Texas, dating primarily from the Late Archaic and later in Late Prehistoric times (Hall 1995; Patterson et al. 1993; Perttula 2001): these include the coastal Rio Grande delta, inland Rio Grande region of southern Texas, the northern Rio Grande Plains and the Nueces River, the South Central Coast, the inland Central Coastal Plain, along and south of the Edwards Plateau in Central Texas, including the Blackland Prairie, the lower ColoradoBrazos rivers, the upper Texas Coast, including Galveston Island (Ricklis 1994), and even in East Texas Caddo sites dating from the $16^{\text {th }}$ to the late $17^{\text {th }}$-early $18^{\text {th }}$ centuries (Perttula 2015; Tom Middlebrook, April 2020 personal communication). Red ochre pieces and powders have been placed in graves, sometimes in quantities sufficient to stain the bones of the deceased, as is the case with the red ochre burials at 41PR12, and red ochre powder was also placed in the graves, "directly above and around the skull and chest or the pelvis and lower extremities, while others were close to, but not in direct contact with the human skeletal remains" (Taylor 1995:393). At the Loma Sandia site (41LK28) on the Nueces River, for example, in a cemetery dating between 850-550 B.C., about 6 percent of the 205 burials had ochre stains, and 11 percent had associated ochre pieces (Taylor 1995). In other cases, red ochre pigments were rubbed on the bones (bone tubes from severed long bone shafts), or sometimes incised or engraved (Hester 1969) prior to their interment.

\section{Grace Bison Skeleton (41PR20)}

An articulated bison skeleton was encountered at ca. $75 \mathrm{~cm}$ bs by Mike Grace when he was excavating ditches on his property, which is a sandy terrace (880-890 feet amsl) that ends at the South Fork of the Trinity River floodplain; Bell Camp and the Red Ochre Burials sites are ca. 0.5 miles to the southeast (Figure 13) on the other side of the river. Norris, with the assistance of the Tarrant County Archeological Society and Bonnie Yates of North Texas State University (now the University of North Texas) excavated the skeleton in June 1985.

The screening of the sand deposits recovered lithic debris $(n=45)$ of Central Texas chert, pebbles, and burned rocks, and exposed an almost completely articulated bison skeleton of about 18 months of age, lying on its right side (Figures 14 and 15), that had been killed and skinned, likely during the Late Archaic period; see close-up images of the skull (Figure 16) and lower ribs and back legs (Figure 17). There were cut marks on the knees and ribs. Apparently, the bison lay in a shallow basin dug out of the red clay subsoil, and in completely exposing the skeleton, a triangular-shaped knife or bilateral flake tool of gray chert (Everett 1990:Figure 3) was recovered by the right eye of the skull, and a broken gray chert dart point tip was exposed by the right hooves (Figure 18). Tan chert lithic debris (see 


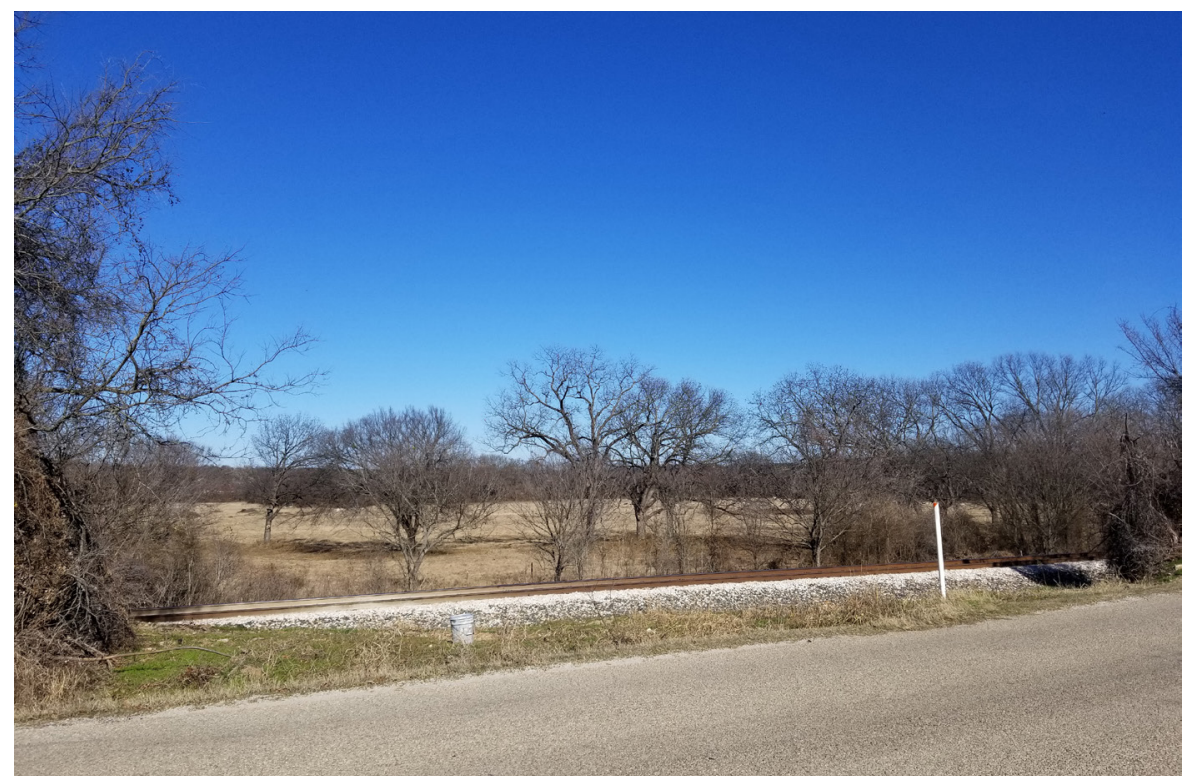

Figure 13. Looking north from Bell Camp and the area of the Red Ochre Burials site towards the Grace Bison Skeleton site (41PR20) in the far left of the photograph. Photography by Lanie Garmon.

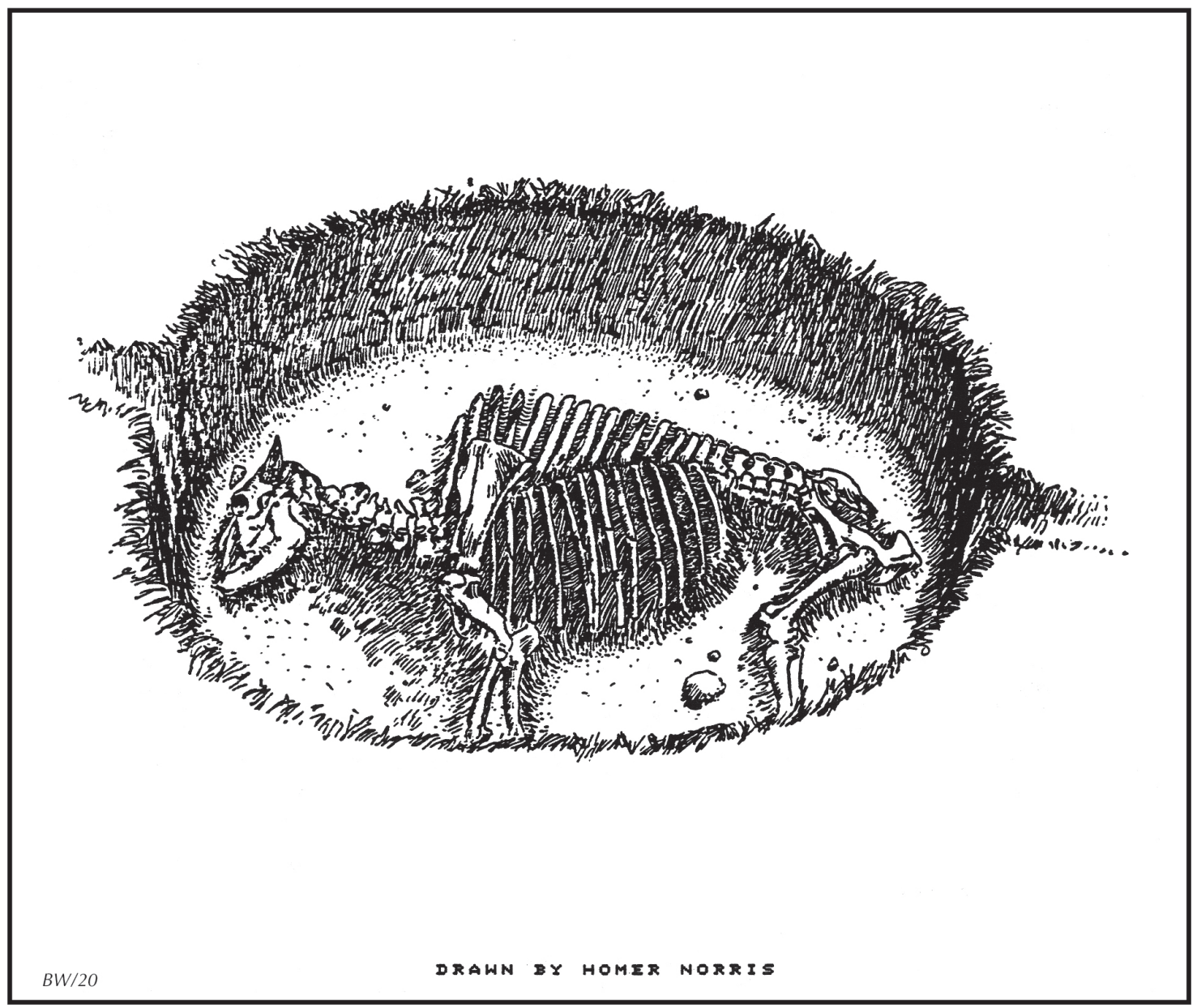

Figure 14. Plan of the Grace bison skeleton at 41PR20. Drawing by Homer Norris. 


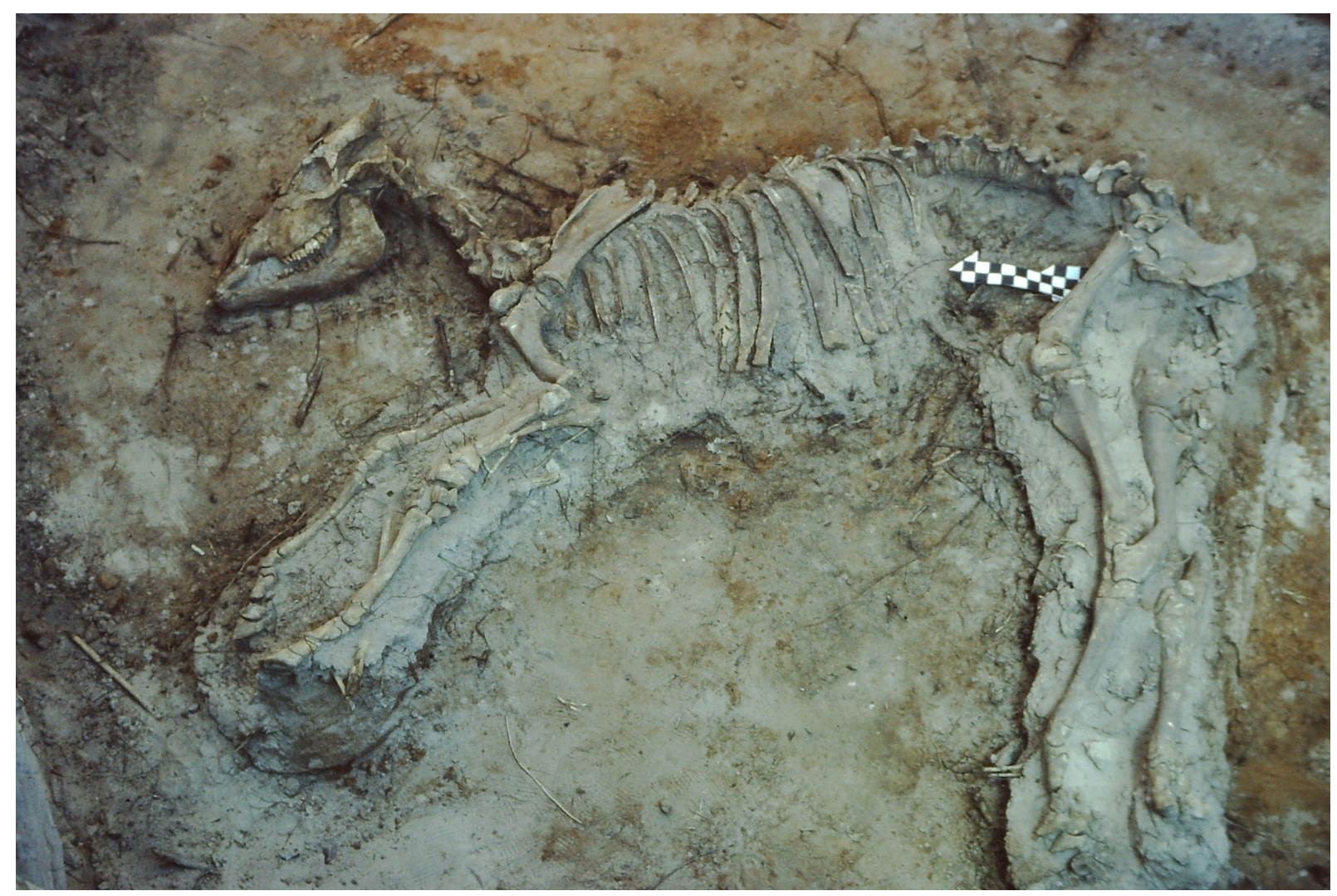

Figure 15. Photograph of the exposed bison skeleton at 41PR20.

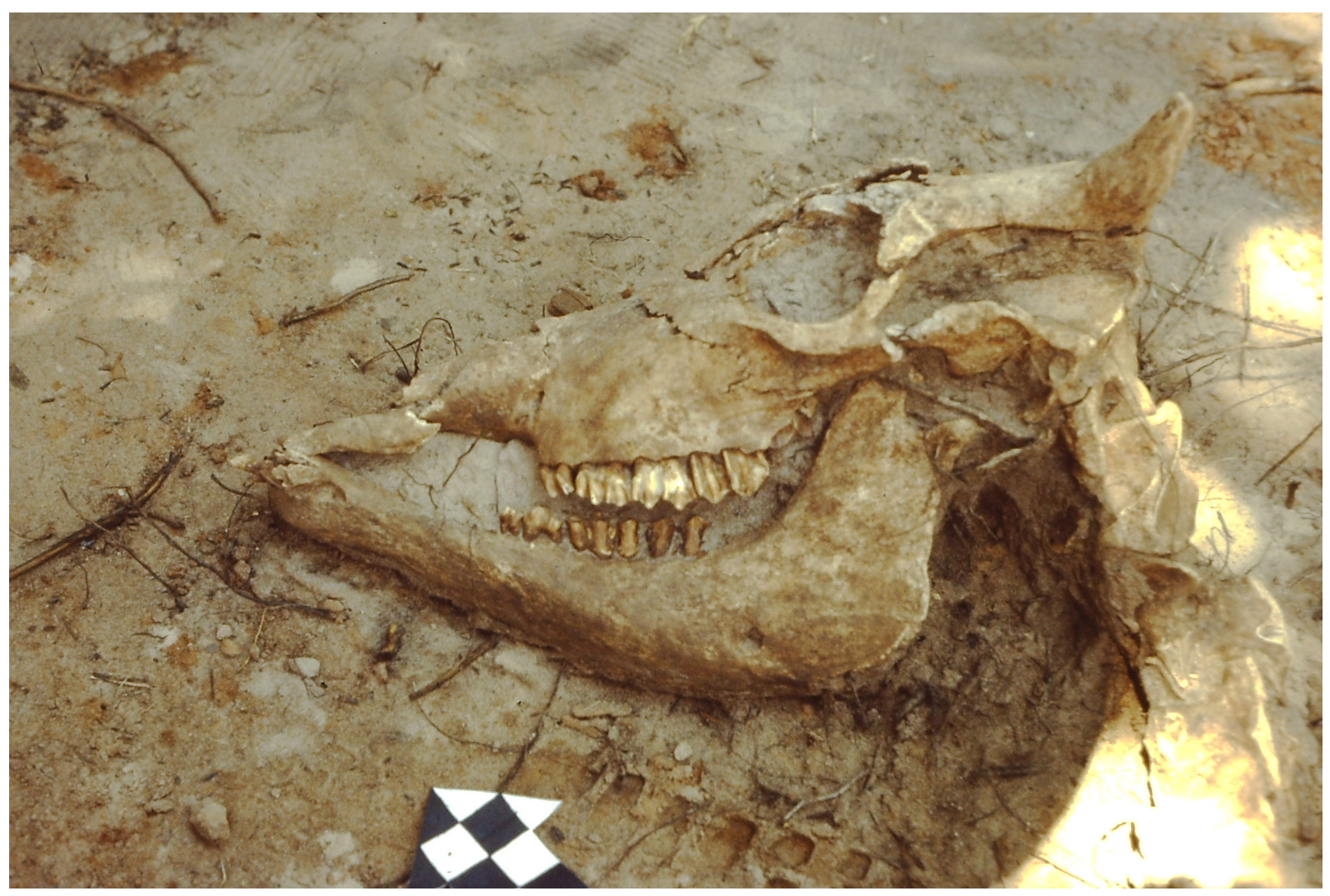

Figure 16. Close-up of the bison skull and mandible at 41PR20. 


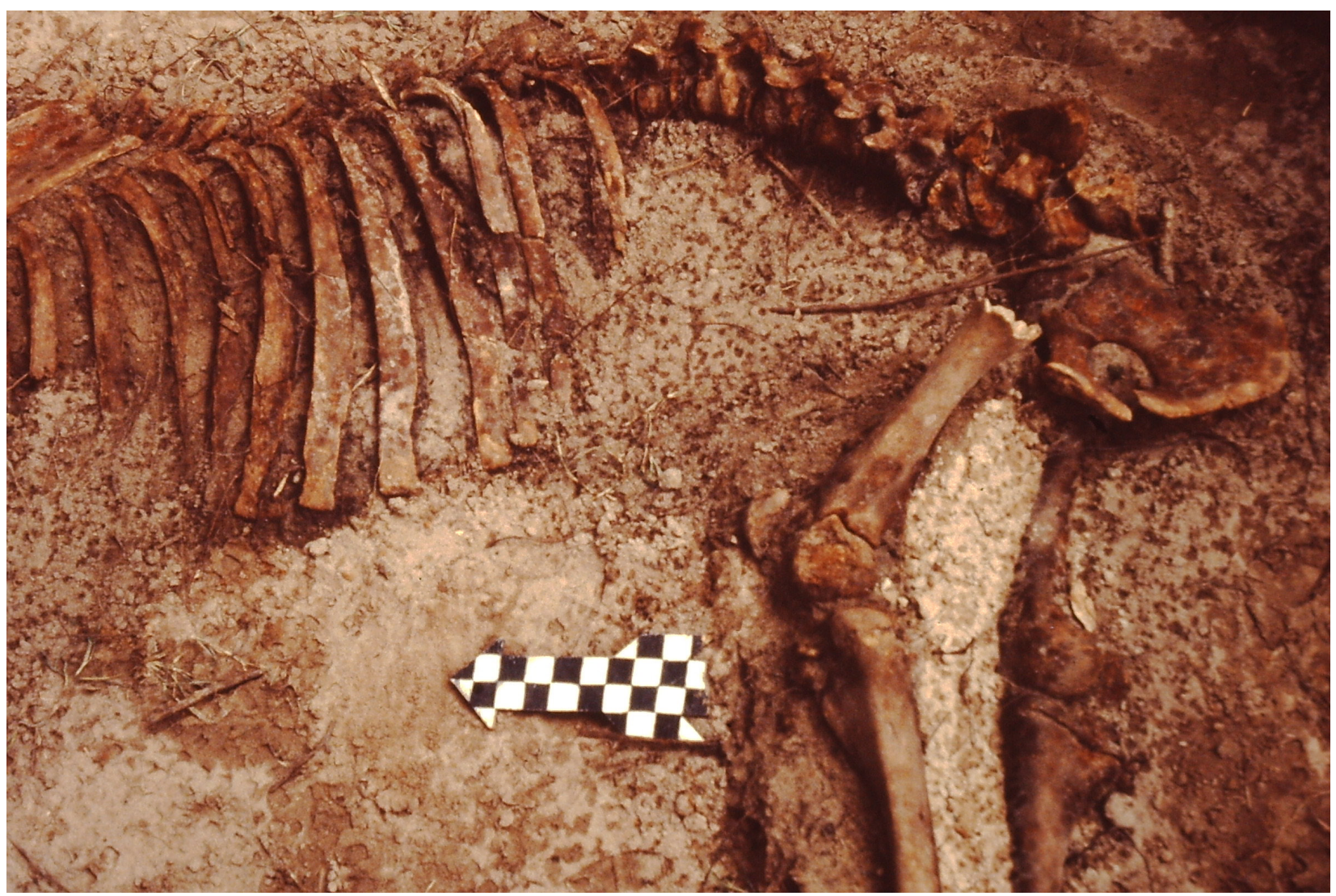

Figure 17. Close up of the lower rib cage and back legs of the bison skeleton at 41PR20.

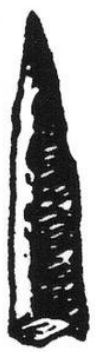

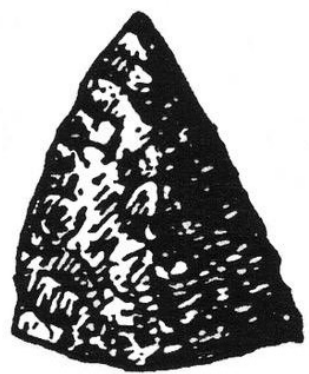

a

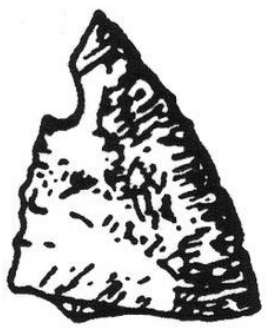

b

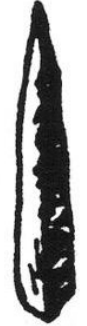

(1)

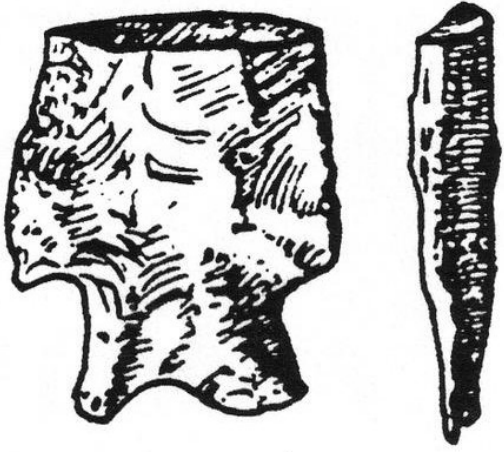

d

Figure 18. Selected chipped stone tools from the Grace Bison Skeleton site. Drawings by Homer Norris. 
Everett 1990:Figures 4-5 and 8) and unilateral flake tools (see Everett 1990:Figures 6 and 7) were also documented in the bison skeleton excavations. The skeleton lay at $57-58 \mathrm{~cm}$ bs (Everett 1990), atop a pavement of ferruginous sandstone slabs. A 9 x $9 \mathrm{~cm}$ charcoal concentration, $3 \mathrm{~cm}$ thick, was noted ca. 1 $\mathrm{m}$ west of the bison vertebrae, but at only $41 \mathrm{~cm}$ bs, above the bison skeleton; this charcoal deposit has not been dated.

Further excavations around the area of the bison skeleton recovered two broken expanding stem and corner-notched dart points of tan chert (see Figure 18). These points, made of a tan chert, may be Late Archaic Edgewood or Ellis points (cf. Prikryl 1990:Figure 24); another Edgewood point of dark gray chert was also found in proximity of the skeleton.

Mike Grace (2020 personal communication) found a rectangular sandstone metate and sandstone manos on the site, about $45 \mathrm{ft}$. from the bison skeleton but years later. Other artifacts found on the surface in the vicinity of the bison skeleton, and in the Mike Grace collection, include a diverse range of projectile points, including a brown chert $\mathrm{cf}$. Dalton of Late Paleoindian age, three early split-stemmed Gower points of gray chert, a white chert Calf Creek point dating from ca. 6000-5700 years ago, and single examples of Trinity, Edgewood (Figure 19), Elam, Darl, and Godley points made from white, brown, gray, and tan chert. A single Bonham arrow point (Grace collection) is also in the collection, as well as 10 chert biface fragments, tips, and preforms, a quartz end-side scraper, a gray chert scraper and drill, a bilateral flake tool and a drill, and a drill and notched biface. A few pieces of chert lithic debris are in the Grace collection from the site.

Norris also reported that when Mike Grace was digging a dirt tank about 75 m southwest of the bison skeleton, he found a reworked and resharpened Plainview point of tan chert. Later Homer and his son John found a broken Plainview point of tan chert and a brown chert biface fragment $70 \mathrm{~m}$ west of the dirt tank in an eroded area.

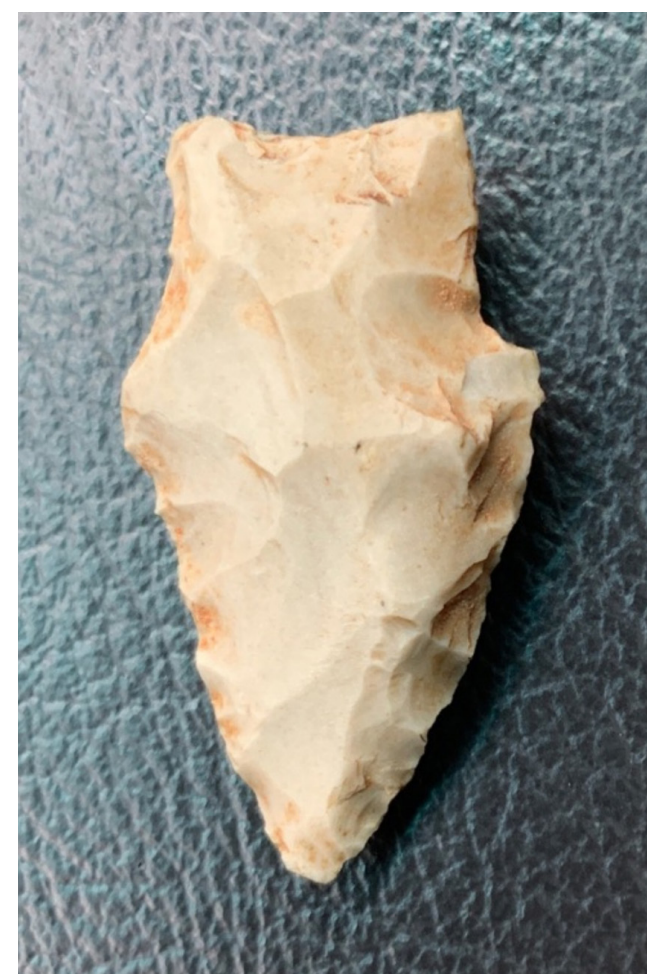

Figure 19. Edgewood point from the surface of the Grace Bison Skeleton site (41PR20). 


\section{Bell Camp (41PR107)}

The Bell Camp site covers several acres of a sandy terrace landform (860-870 feet amsl) ca. 150 m southeast of Burgess Creek and ca. 300 m southwest of the South Fork of the Trinity River. It encompasses several localities, including the Red Ochre Burials site and other areas with habitation deposits. The State of Texas Archeological Data Site Form indicates that the upper $25 \mathrm{~cm}$ of the deposit contains Late Prehistoric arrow points and pottery sherds, separated by a sterile yellow sand from a lower-lying Late Archaic deposit with charcoal-blackened sand, fire-cracked rocks, and chipped stone tools; this deposit extends to ca. $75 \mathrm{~cm}$ bs.

In 1973-1975 Homer Norris and friends excavated an area of at least 6 square meters (in 37 separate units of varying sizes, labeled A-Z and 1-12) on the crest of the landform. The archeological deposits in the units ranged from ca. $0-71 \mathrm{~cm}$ bs; the densest concentrations of artifacts and charcoal pieces were between $0-15 \mathrm{~cm}$ bs. Norris noted several post holes in his excavations, suggesting his excavations were in the area of a Late Prehistoric structure.

Recovered in those excavations were 38 arrow points - all but one of the Alba type (Figure 20) made from light gray, gray, yellowish-gray, and yellowish-brown chert; the other is a side-notched Washita point of yellowish-gray chert from a later post-A.D. 1250 aboriginal occupation. Also recovered were a few expanding stem and corner-notched Ellis dart points, as well as Gary, Hoxie, Kent, and Carrollton points, much lithic debris ( $n=377+$ pieces) and core fragments, end and side scrapers $(n=26)$, a lanceolate-shaped bifacial knive of gray chert with bilateral retouch and use wear, other chipped stone tools $(\mathrm{n}=15$, flake tools, drills, and gravers), a corner-tanged knife of gray chert (Figure 21), and sandstone ground stone tool fragments $(n=11)$, including manos and pitted stones. There were also at least 71 pieces of mainly burned animal bones from deer, bison, squirrel, fish, and rabbit and freshwater mussel shell $(n=82)$. Other arrow points in the Norris collections from the Bell Camp site also include Bonham, Catahoula, and Scallorn types as well as later post-A.D. 1250 Perdiz, Fresno, and Washita arrow points, all made from cherts.

Several other side-notched points $(n=5)$ in the collection from the Bell Camp site may be from an unknown local type (Thomas R. Hester, January 2020 personal communication), perhaps a variety of Washita point, with deep and concave bases and prominently serrated blades and bases, typically three serrations on each side of the blade and one serration on each side of the base (Figure 22). They are made from non-local cherts ranging from light gray, gray, white, and yellowish-gray colors. I have dubbed them Washita, var. Norris arrow points.

Martin (1994:Figure 28g, j, u, w, cc) illustrates several very similar serrated blade and base arrow points from the Dillard site (41CO174) on the Red River in Cooke County, Texas, and he identified them as Washita points; his examples, however, tend to have flat to shallow concave bases, unlike those from the Bell Camp site. These Dillard site arrow points date from A.D. 1260-1420 based on calibrated age ranges (Martin 1994:Table 12). Rohn (1998:Figure 35, right and Table 2) recovered one var. Norris point from the Haley's Point site (34MA15) on the Red River in archeological deposits that range from A.D. 1150-1295 to as late as A.D. 1385.

A number of Washita, var. Norris arrow points have been recovered from 41PR126 (Figure 23) by Art Tawater in the 1990s (Bryan Jameson, April 2020 personal communication). This site is near Dennis, Texas, and just south of the Brazos River, ca. $25 \mathrm{~km}$ from the Bell Camp site.

Other sites in North Central Texas with arrow points with very similar stylistic attributes are known from 41RW1 in Rockwall County and 41COL34 in Collin County (Wilson W. Crook, III, March 2020 


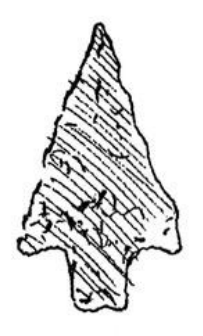

a

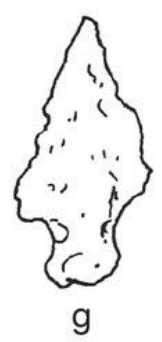

$\mathrm{g}$

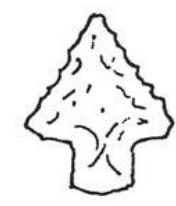

I

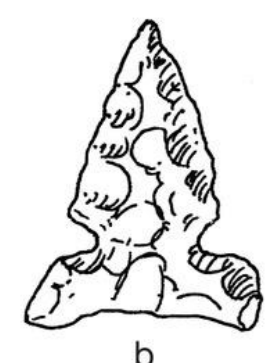

b

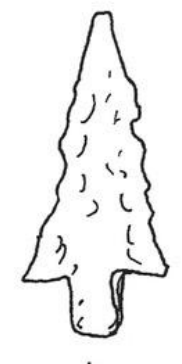

h

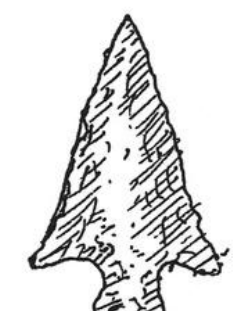

m

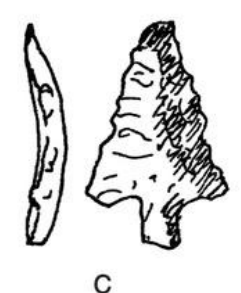

C
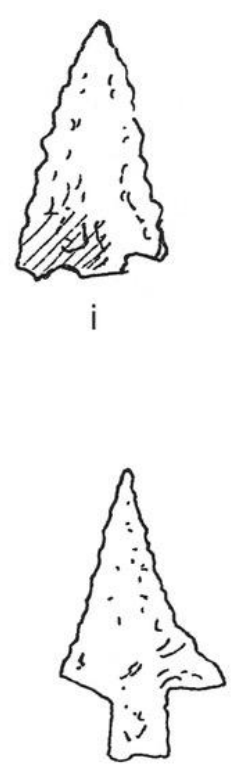

n
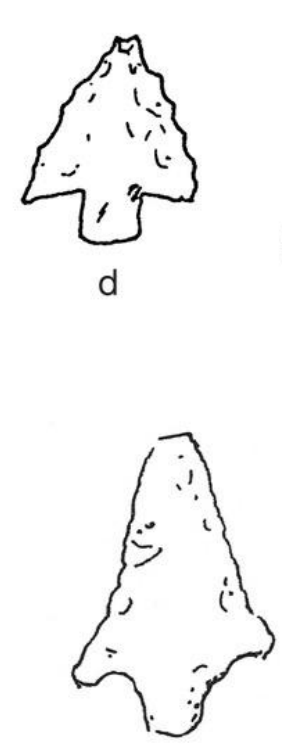

J
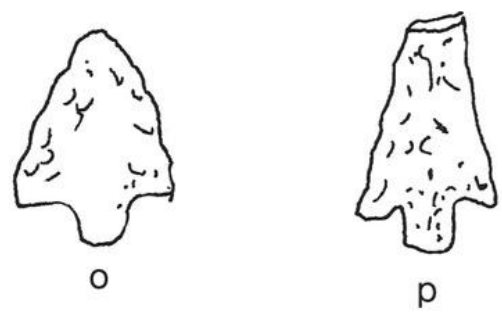

Figure 20. Selected arrow points from 1973-1975 excavations by Homer Norris at the Bell Camp site. Drawings by Homer Norris.

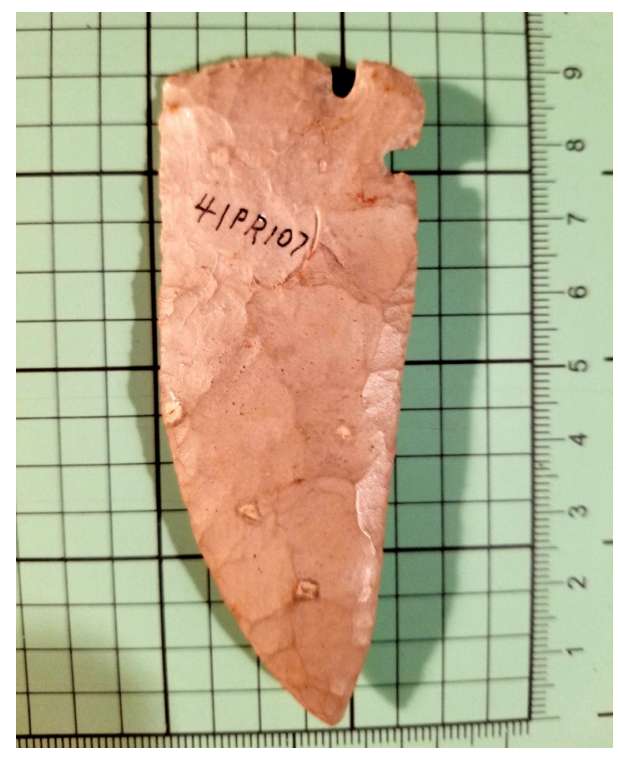

Figure 21. Corner-tanged knife from the Bell Camp site. 

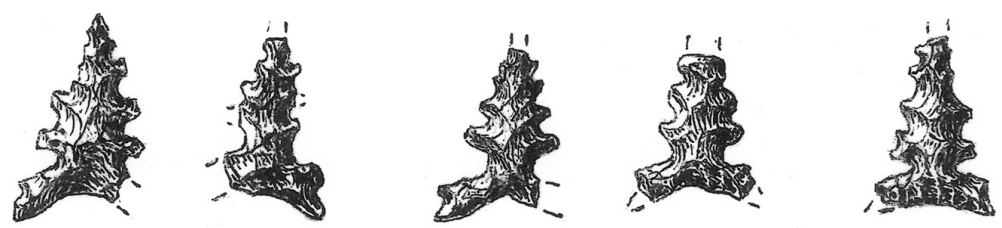

Figure 22. Washita, var. Norris side notched arrow points from the Bell Camp site. Illustration provided by Richard McReynolds.

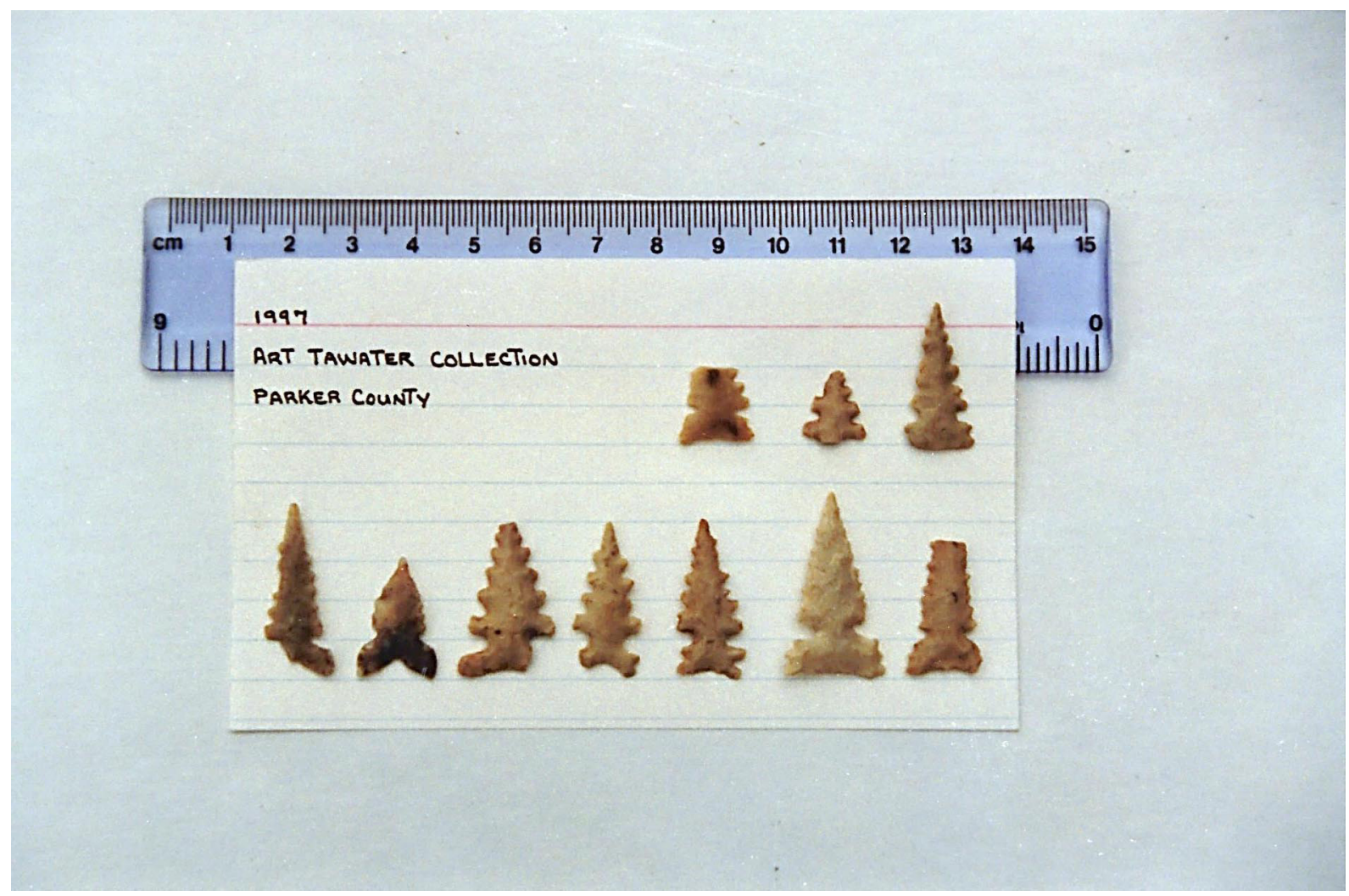

Figure 23. Washita, var. Norris arrow points from 41PR126. Photograph courtesy of James Everett.

personal communication); these were of white and pink-colored cherts, probably Central Texas chert or Alibates flint from the Texas Panhandle (Jay Newman, 2020 personal communication). The Baggett Branch site (41DL149) at Joe Pool Lake in Dallas County had a similar arrow point form (see Peter and McGregor 1988:Figure 10-6a; Dan McGregor, March 2020 personal communication), and there are 10+ specimens from 41DL11, 41DN4, 41DN10, and 41DN31 in Dallas and Denton counties (Dan Prikryl, March 2020 personal communication). This form of eared and heavily serrated arrow point type is also known from eastern New Mexico sites, although they do not have a type name at the present time (Jay Newman, March 2020 personal communication).

This work at the Bell Camp site also recovered 23 ceramic vessel sherds, including several with fingernail punctations, from what Prikryl (1990:Figure 24) calls the Late Prehistoric I period, ending at ca. A.D. 1200. The one sherd still remaining and accessible in the Norris collection is a thick (9.6 $\mathrm{mm}$ ) grog-tempered body sherd from a vessel fired in a reducing environment and then cooled in the 
open air. The sherd has several rows of fingernail punctations (see also Ellis et al. 2015:173; Todd et al. 2009:Figure 3).

The Late Prehistoric pottery sherds from the Bell Camp (as well as the Railroad Crossing site, see below) are from ca. A.D. 900-1200 Early Caddo period, Alto phase, vessels made in East Texas, likely by ancestral Caddo peoples living along the Neches River (see Newell and Krieger 1949; Story 2000; Suhm and Jelks 1962) in the Pineywoods well to the southeast of the South Fork of the Trinity River. These vessels, and their contents, were likely traded/exchanged between the Caddo and the local South Fork aboriginal peoples, probably for bison products and lithic raw materials. The sherds from Bell Camp are from Crockett Curvilinear Incised, Hickory Engraved, Kiam Incised, Pennington Punctated-Incised, Weches Fingernail Impressed, var. Weches (see Stokes and Woodring 1981), and Wilkinson Punctated types (Figure 24); the punctated sherds from utility ware jars appear to have been the most common ceramics at the bell Camp site.

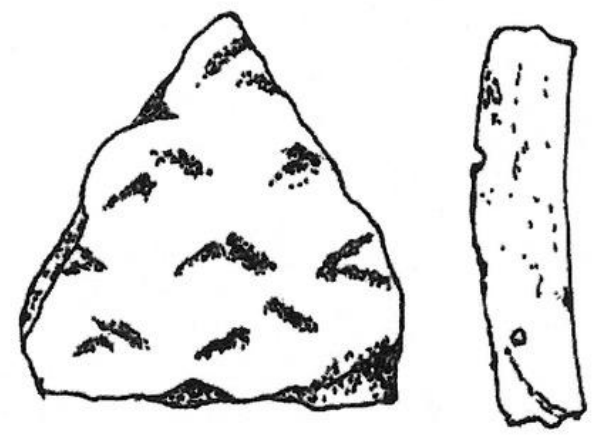

a

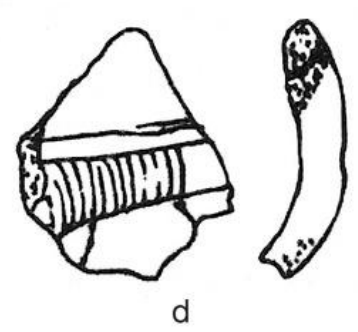

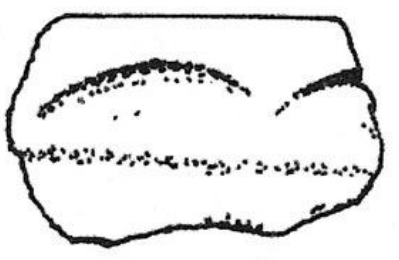

b

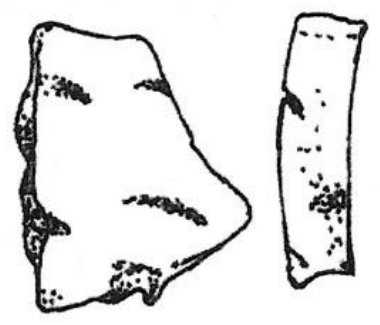

e
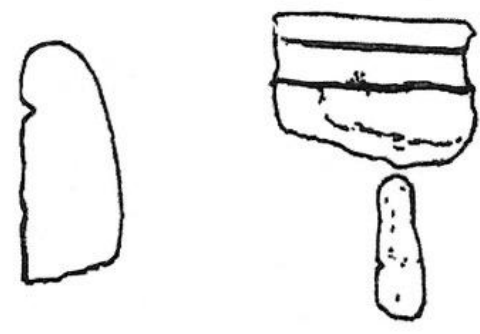

C

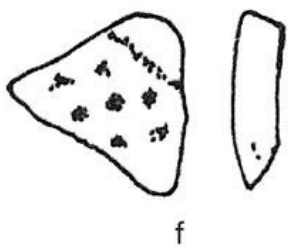

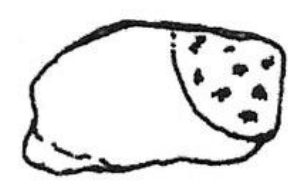

g

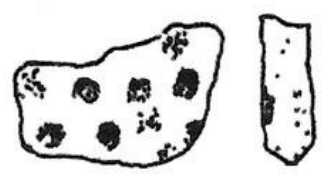

$\mathrm{h}$

Figure 24. Early Caddo period ceramic vessel sherds from the Bell Camp and Railroad Crossing sites: a, e, fingernail punctated body sherd; b, Weches Fingernail Impressed rim sherd; c, Davis Incised rim sherd; d, Crockett Curvilinear Incised body sherd; f, Pennington Punctated-Incised body sherd; g, Crockett Curvilinear Incised body sherd; $h$, cane punctated body sherd. Drawings by Homer Norris. 


\section{Railroad Crossing}

The Railroad Crossing site is on a low upland landform next to the Frisco Railroad, with the South Fork to the north, and near Burgess Creek. Norris estimated that this place is ca. $200 \mathrm{~m}$ east of Bell Camp, and he had found on the surface numerous arrow points (mostly of the Alba type), pottery sherds, animal bones, fire-reddened limestone pieces, and sandstone fragments, as well as Late Archaic dart points (Figure 25).

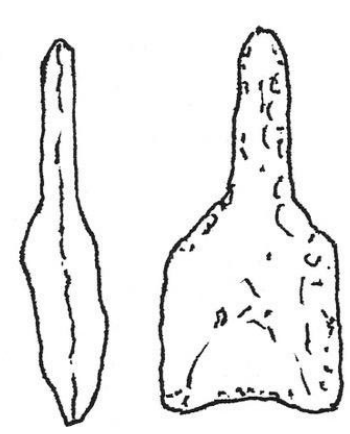

a

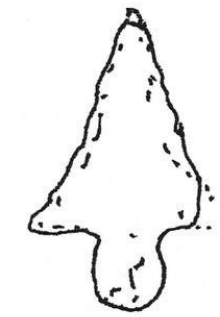

d
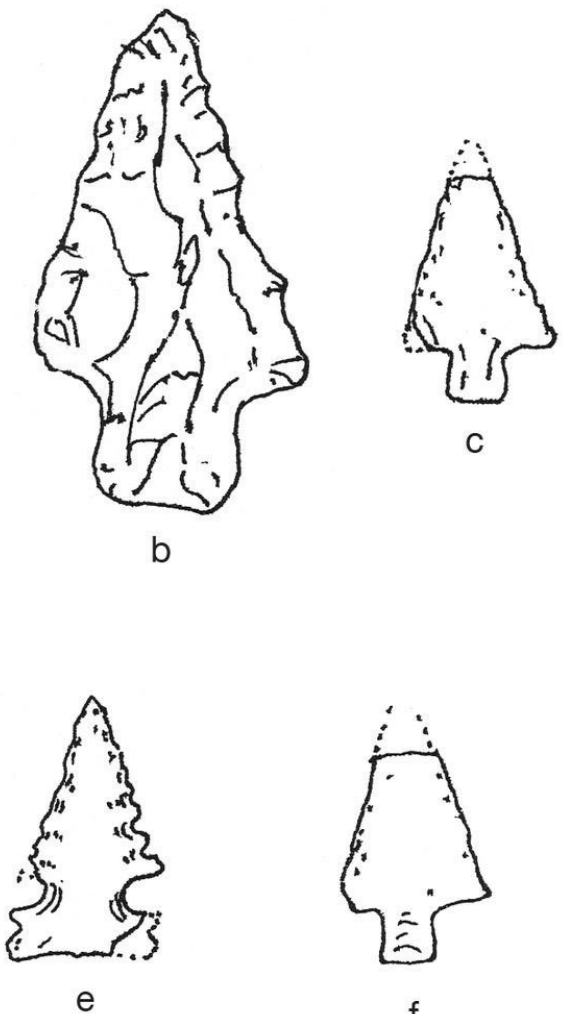

e

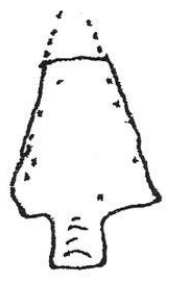

f

Figure 25. Selected artifacts from the Railroad Crossing site. Drawings by Homer Norris.

Additional artifacts in the Norris collection from the Railroad Crossing site include tan chert and gray chert Carrollton dart points, two dart point tips, and a dart point mid-section, as well as three gray and light gray chert arrow point preforms. There is also a tan chert biface fragment, a brown chert drill, a gray chert unifacial flake tool, a sandstone grooved abrader, and 10 pieces of chert and quartzite lithic debris.

\section{Norwood Camp (41PR105)}

Norris investigated the Norwood Camp site in 1967 in what was left of the site after gravel mining in the late 1920s. The site is on the floodplain (830 feet amsl) south $200 \mathrm{~m}$ of the South Fork Trinity River. According to Norris' notes, a Native American burial had been exposed and excavated at the site during the mining operations. Norris recovered an arrow point at the very edge of where the burial had been excavated years before.

The work done by Norris consisted of excavating several test pits along the edge of the gravel pit; the site may have covered a ca. 35 x 35 m area. In that work, he recovered from between $12-35 \mathrm{~cm}$ bs a Late 
Archaic Ellis dart point and several post-A.D. 700 to post-A.D. 1200 arrow points, including a Scallorn of gray chert, a possible Alba, a possible Perdiz, and an arrow point preform (Figure 26), indicating use of the Norwood Camp site in both Late Archaic and Late Prehistoric times. Lohse et al. (2014) date the manufacture and use of Ellis point from ca. 200 B.C.-A.D. 680. Other recovered artifacts include

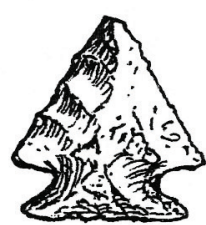

a

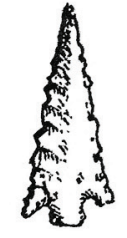

b
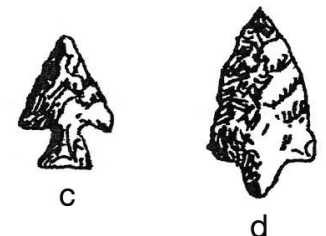

d

Figure 26. Selected artifacts from the Norwood Camp site. Drawings by Homer Norris.

dart point fragments (including one cf. Trinity point of gray chert), a flake scraper, a gray chert biface fragment, a sandstone mano/pitted stone, an abraded and scratched piece of red ochre (Figure 27), and several pieces of burned and unburned deer bone.

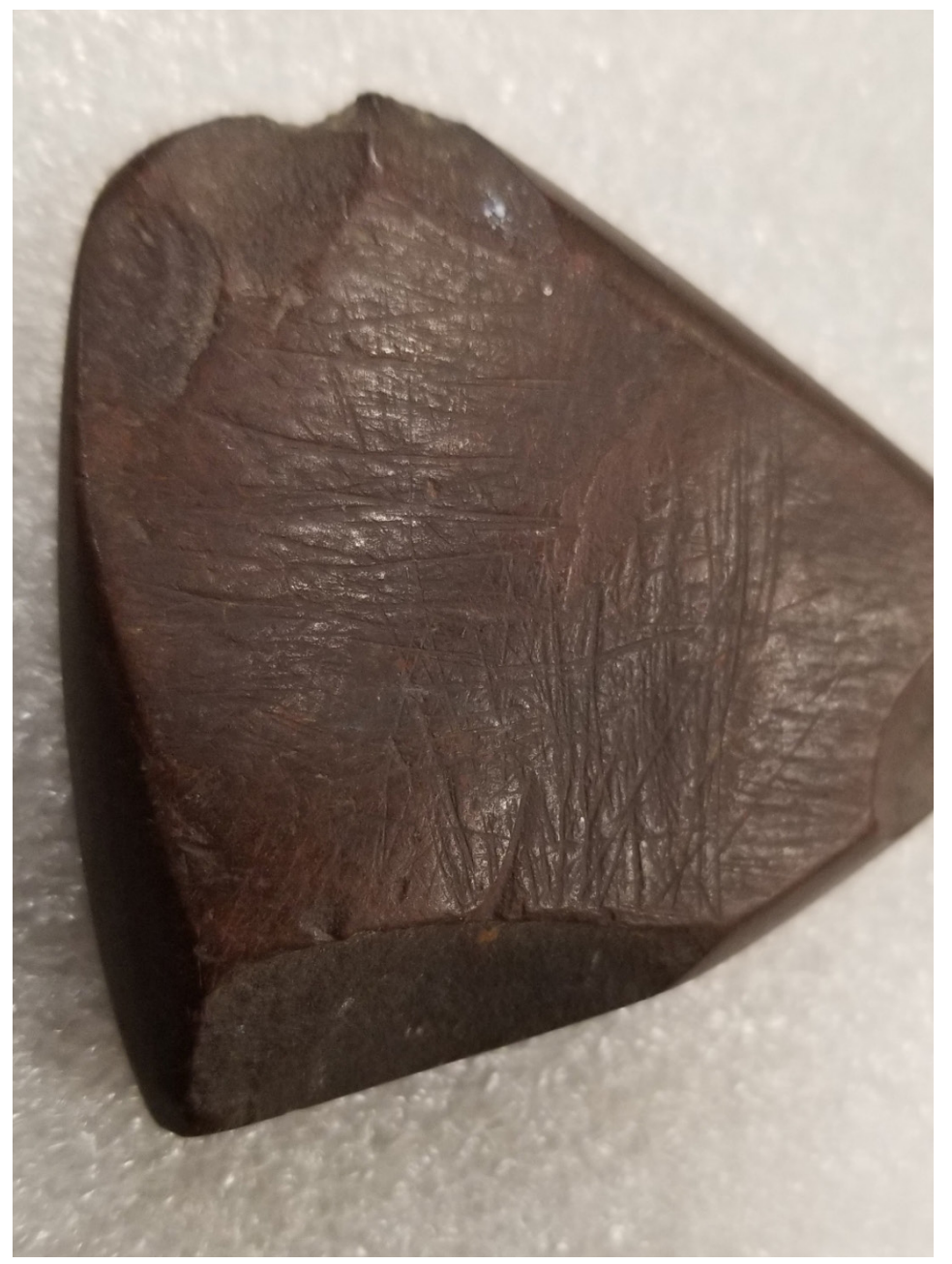

Figure 27. Scratched and abraded piece of red ochre from the Norwood camp site. Photograph by Lanie Garmon. 


\section{Sandy Camp (41PR108)}

This prehistoric site was investigated by Homer Norris between 1965-1990. It is on an upland landform (880-890 feet amsl) overlooking the valley of a small stream that drains north into the South Fork of the Trinity River. It is estimated that the site covers a ca. 150 x $500 \mathrm{~m}$ area, or more than 18 acres of the landform, with deposits from ca. 10-45 cm bs.

After a heavy rain in 1965, Norris observed a number of fire-reddened cobbles in a ca. $50 \mathrm{~cm}$ deep eroded depression. When he removed the cobbles, he exposed a flexed burial with portions of the skull, ribs, and long bones (Figure 28). Found associated with the burial were a piece of sandstone, possibly

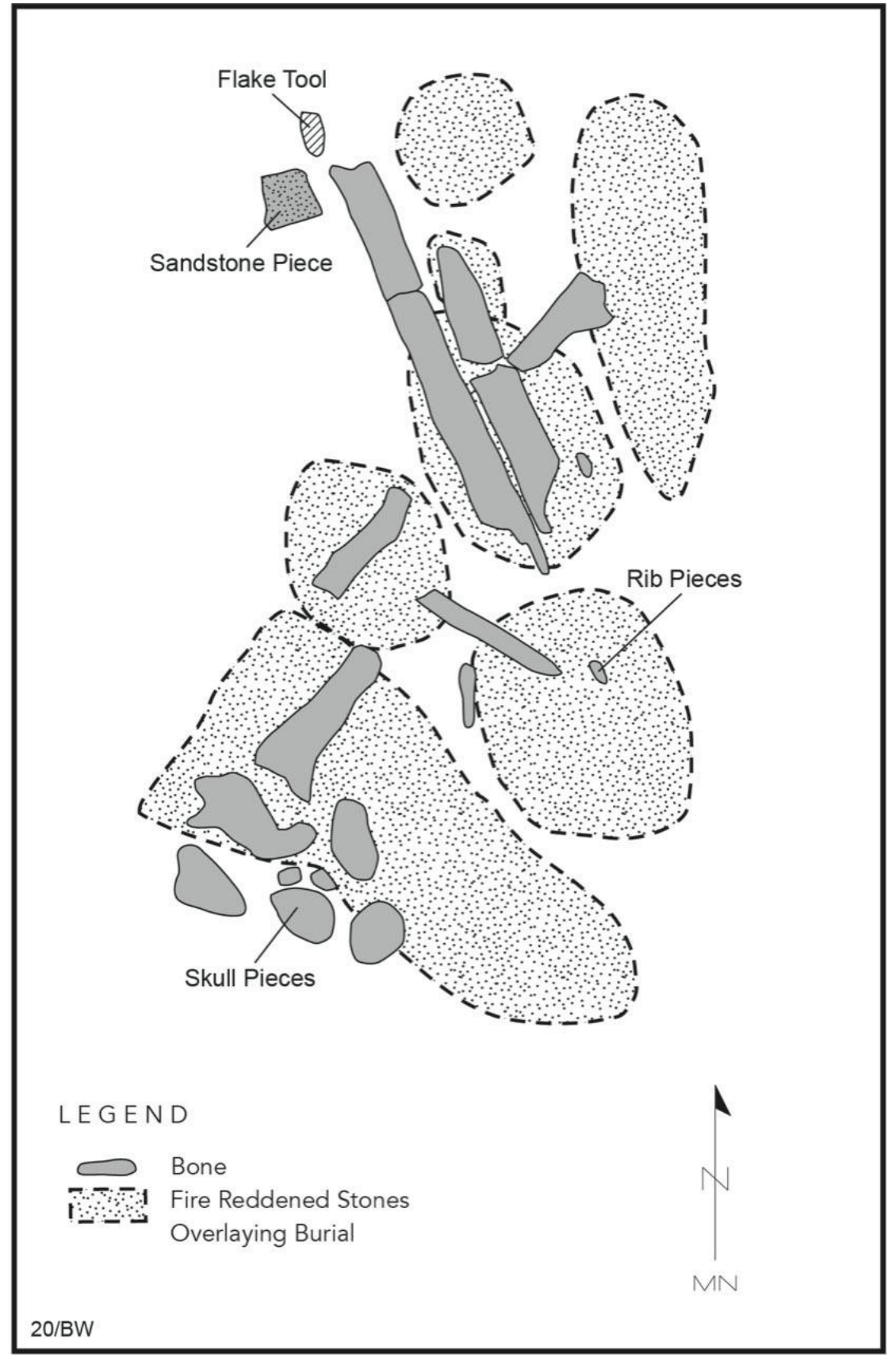

Figure 28. Plan map of the burial at the Sandy Camp site. 
a mano, and a flake tool (Figure 29). According to Norris' notes, Dr. Alan Skinner examined the human remains, and suggested they were from a male that had been buried ca. 1000 B.C.

Numerous Middle to Late Archaic dart points with straight to expanding stems had been recovered from the surface of the Sandy Camp over the years (see Figure 29), including a grayish-white Ellis point, a tan chert Carrollton, a black speckled light gray chert Edgewood, and a light gray Early Split Stem or Gower point, along with biface fragments, flake tools, a gray chert core fragment, and lithic debris, as well as one $18^{\text {th }}$ century round $(13.2 \mathrm{~mm}$ in diameter) aquamarine glass trade bead. In 1990, Norris excavated using a trowel a number of $1 \times 1 \mathrm{~m}$ units at the site, including Units 1-4 in a block about $45 \mathrm{~m}$ northwest of the previously recovered burial. Three other north-south aligned units (A-C) were also excavated at this time, but the location of these units within the site was not specified in Norris' notes.

Unit 1 encountered archeological deposits between ca. 8-14 cm bs, and included lithic debris $(\mathrm{n}=16)$, a scraper, a chipped stone gouge, a flake tool, two pieces of a broken grinding slab, and two fire-cracked rocks. In Unit 2, archeological materials were recovered between $5-23 \mathrm{~cm}$ bs. These materials were a quartzite Gary dart point, lithic debris $(n=33)$, fire-cracked rock (including a small cluster in one part of the unit, along with fire-reddened sand), and a broken ground stone pestle. Unit 3 had lithic debris $(n=22)$, thought to be from Brazos River chert sources, several flake tools, small pieces of red ochre, and fire-cracked rock between 10-30 cm bs. Unit 4 had comparable archeological materials to $24 \mathrm{~cm}$ bs, including lithic debris $(\mathrm{n}=17)$, a graver, a red ochre piece, and fire-reddened and fire-cracked rock.

Excavations in Units A-C encountered a significant concentration of burned and fire-reddened limestone rocks at ca. $22 \mathrm{~cm} \mathrm{bs,} \mathrm{extending} \mathrm{to} 34 \mathrm{~cm}$ bs (Figure 30). This is likely the remnants of a $2 \mathrm{~m}$ long hot rock cooking feature (cf. Black and Thoms 2014) with associated scatters of rock raked out of the feature. There
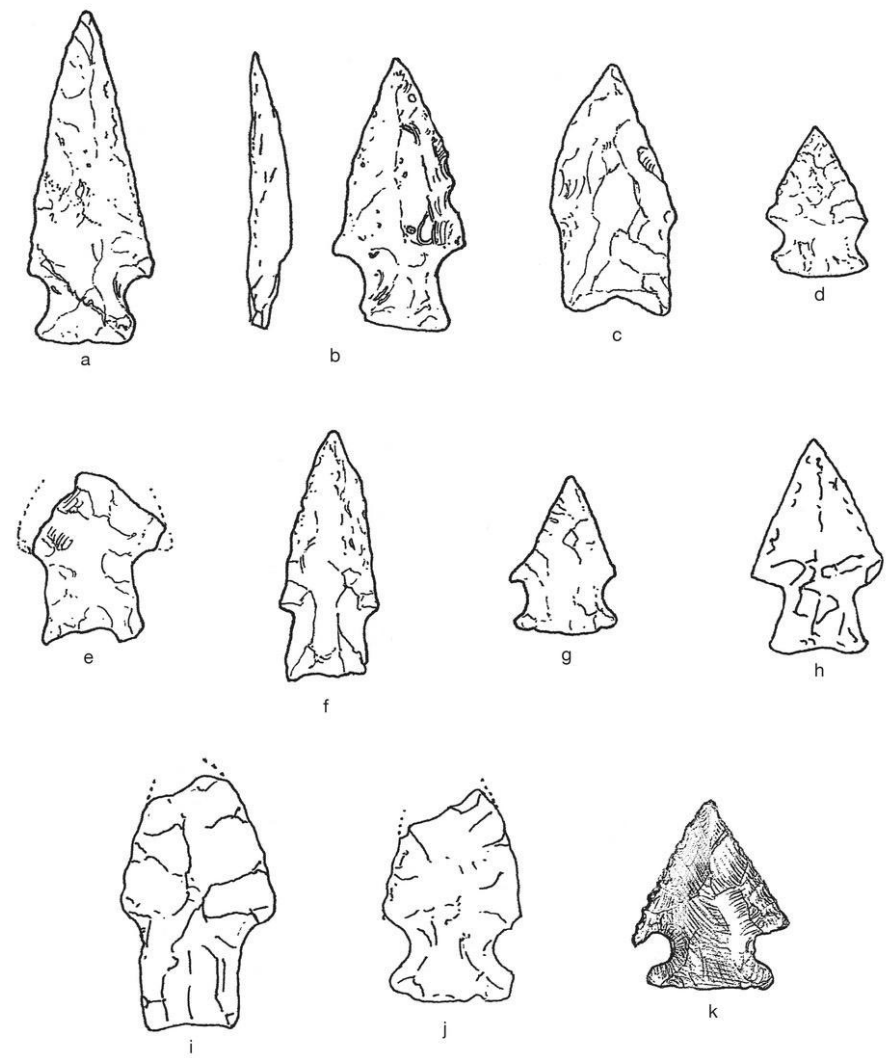

Figure 29. Selected dart points and tools found at the Sandy Camp site. Drawings by Homer Norris. 


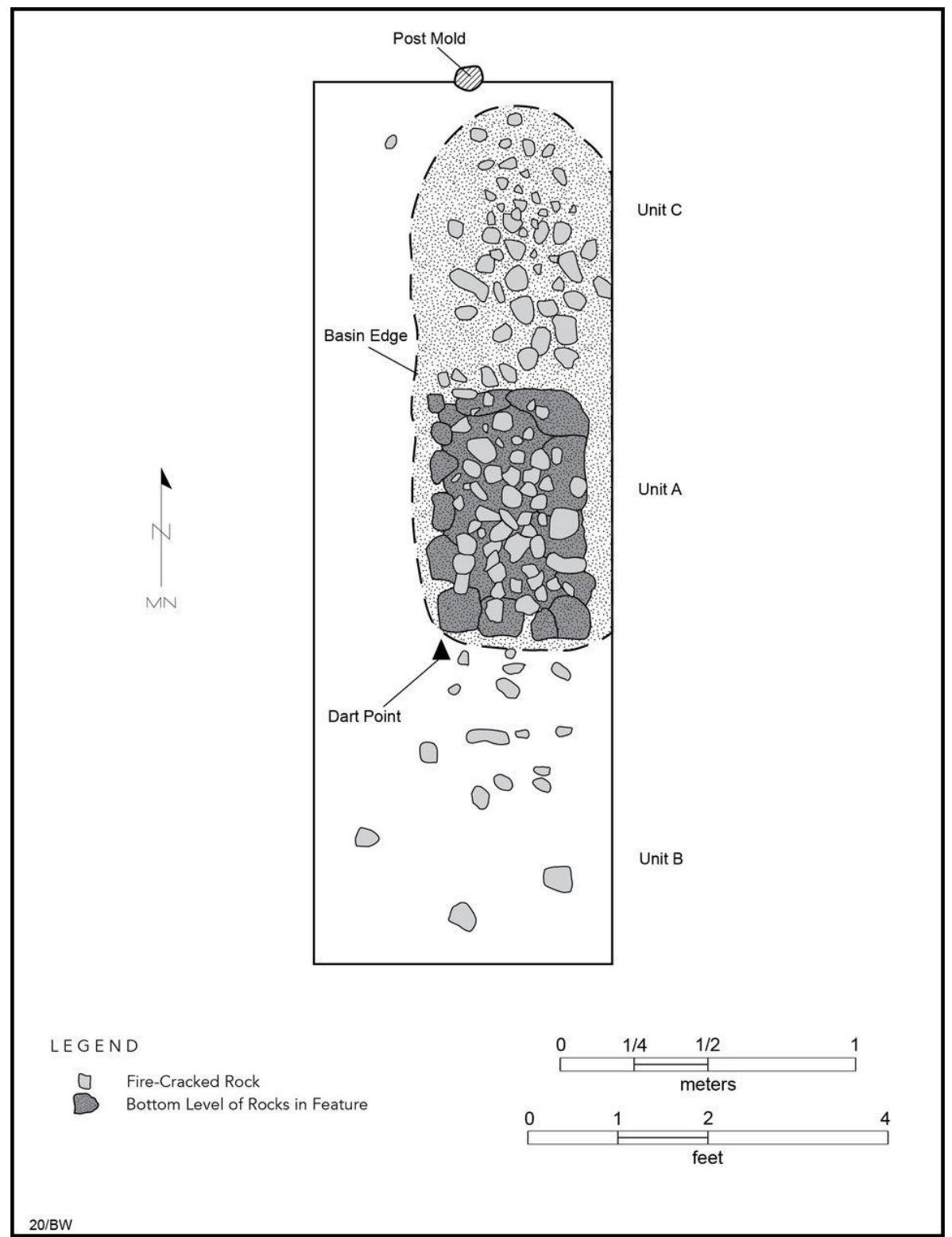

Figure 30. Plan of burned rock feature and associated burned rock scatter in Units A-C at the Sandy Camp site. Drawing by Homer Norris.

was a 2-cm fragment of a sandstone metate in the feature. Just above the feature was a Late Archaic Ellis dart point (see Figure 29). Several unburned animal bones, possibly bird bones, were found at $7 \mathrm{~cm} \mathrm{bs}$.

In Unit A, there were 31 pieces of lithic debris, sandstone fire-cracked rock, small pieces of red ochre, a quartz multi-platform core, and a white chert side scraper. The Norris collection also had a white chert piece of lithic debris in Unit B and a sandstone fire-cracked rock in Unit C.

\section{Fire Wagon Factory Camp (41PR109)}

The Fire Wagon Factory Camp is a multi-component prehistoric site of Paleoindian to Late Prehistoric age on a sandy upland ridge landform (850-880 ft. amsl) in the South Fork Trinity River 
valley. The site may cover ca. 4 acres of the landform and has archeological deposits in deep loamy fine sand that extend to ca. $75-85 \mathrm{~cm}$ bs.

Norris had collected a number of dart points from the surface of the site over the years, including Clovis (Figure 31a-b) and Plainview points, as well as a range of Archaic types, including Darl, Gary, Hoxie, and Williams points. In 1980, he excavated several 1 x $1 \mathrm{~m}$ test unit in the central part of the landform and in Unit B he encountered two buried occupational horizons, one at ca. $20 \mathrm{~cm} \mathrm{bs}$, where he encountered a significant concentration of lithic debris, and the other at ca. $76 \mathrm{~cm}$ bs. This latter deposit had fire-cracked rocks, cores, and manos. A Late Archaic Bulverde point (dating from ca. 4100-3600 years B.P., see Lohse et al. 2014) was recovered at ca. $60 \mathrm{~cm}$ bs (Figure 31e). Other prehistoric artifacts recovered in this work include Lange, Elam, and Ellis dart points, unifacial scrapers, gouges, drilled sandstone pieces, and several probable Alba arrow points; these latter were concentrated in a small area on the eastern part of the landform.
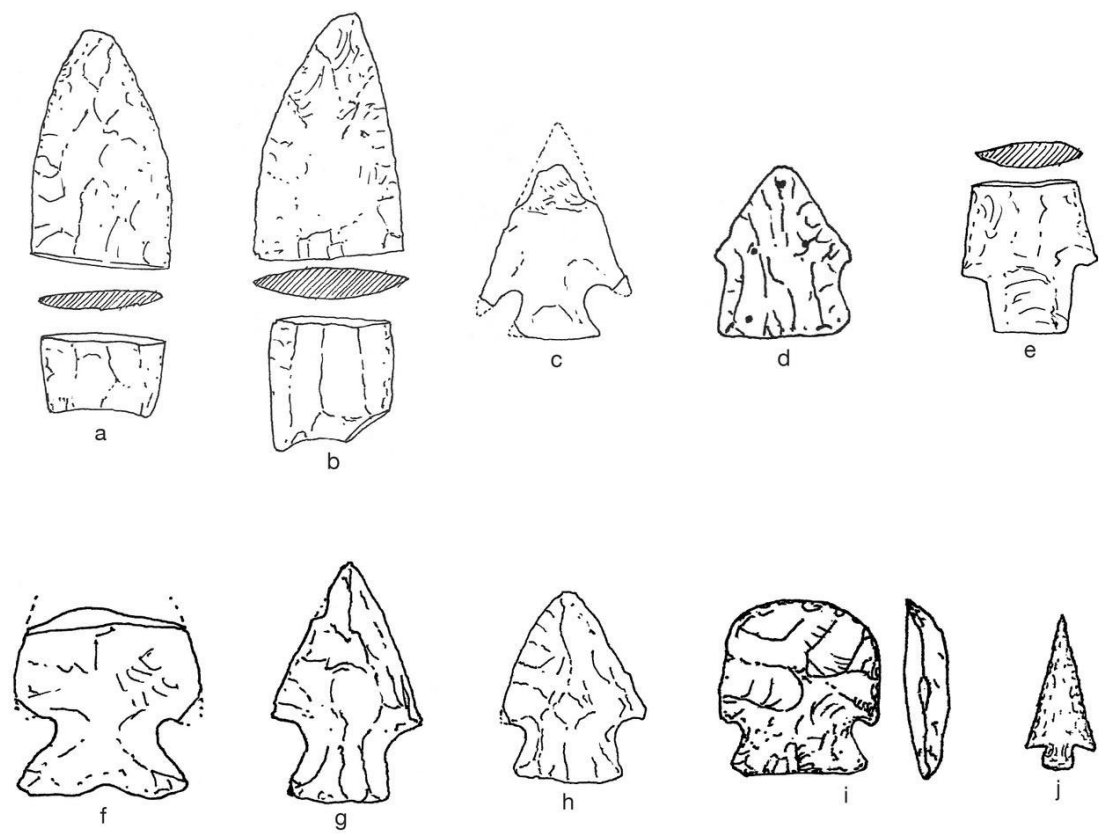

Figure 31. Selected artifacts from the Fire Wagon Factory Camp. Drawings by Homer Norris.

Also in the Norris collection from the Fire Wagon Factory Camp site are an assortment of chipped and ground stone artifacts. Among the chipped artifacts are several dart points: a gray chert early splitstemmed form; a gray chert Elam point; a Gary, var. Camden dart point likely made and used between ca. A.D. 400-700 (see Schambach 1982; Leith 2014); two chert dart point tips; a tan chert Fresno arrow point; and a tan chert arrow point preform. There are also chert biface fragments, end and side scrapers, chert flake tools with unifacial use-wear and retouch, several cores, and chert lithic debris. The ground stone artifacts include a 2 -sided sandstone mano and a 1-sided ferruginous sandstone pitted stone.

\section{Tim Slaton's}

Tim Slaton's site is in the uplands ( 880 feet amsl) overlooking Little Deer Creek, a tributary that flows north to the South Fork. Norris noted a continuous scatter of chipped stone and burned rocks from here to the Fire Wagon Factory Camp site. In an area of an orchard on the property were both Archaic and Late 
Prehistoric artifacts. The site has been heavily damaged by construction of a golf course since Norris investigated it in 1990. Found on the surface and in gopher mounds were a grayish-white chert resharpened Plainview point and Middle and Late Archaic dart points and flake tools (Figure 32). Norris also noted that he "found pottery sherds... at Tim Slaton's orchard, and only in a very limited amount there."
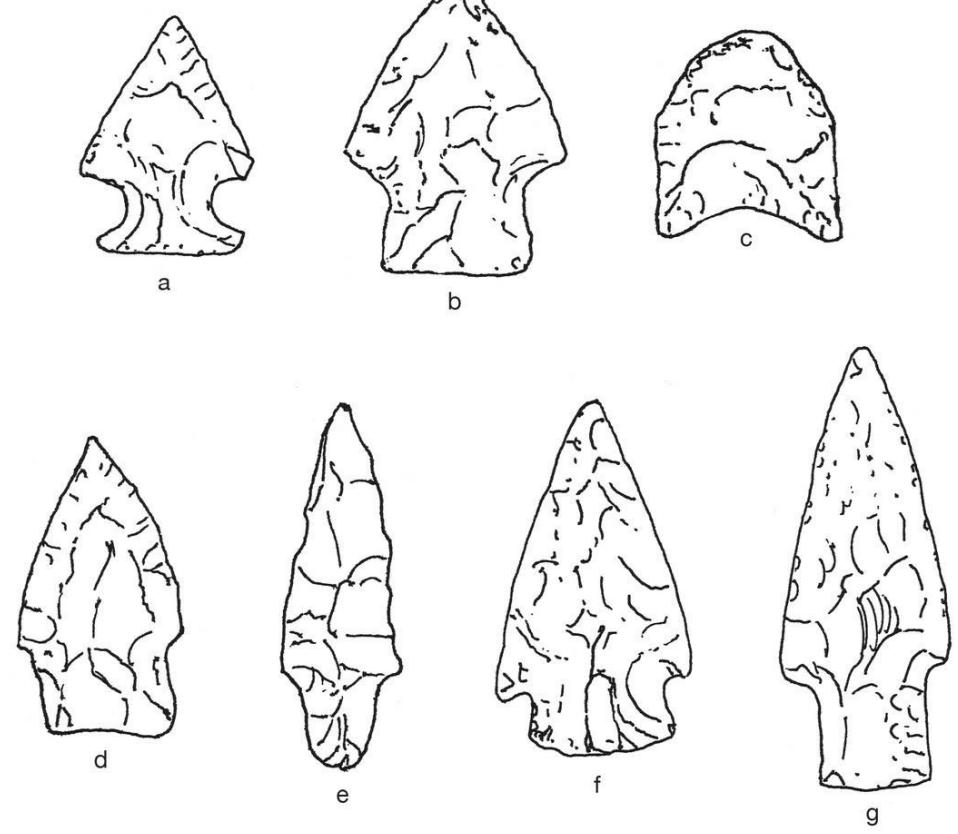

Figure 32. Selected artifacts from Tim Slaton's site. Drawings by Homer Norris.

Other artifacts in the Norris collection from Tim Slaton's site include tan chert biface fragments $(n=3)$, chert end and side scrapers, chert flake tools $(n=2)$, and a few pieces of lithic debris. Norris also collected a single piece of burned animal bone.

\section{Slough by Tim Slaton's}

Norris collected a cf. Perdiz arrow point made of obsidian along an upland slope (870 feet amsl) below and to the east of Tim Slaton's site, and overlooking a slough that drains north to the South Fork of the Trinity River. The obsidian arrow point was submitted in February 2020 to the Texas Obsidian Project for sourcing, and it was analyzed by XRF at the Missouri University Research Reactor. Although it macroscopically resembled Malad, Idaho, obsidian (Thomas R. Hester, March 2020 personal communication), the source of the obsidian could not be confirmed by the XRF analysis.

\section{Hull Camp}

The Hull Camp site is on an upland landform (900-910 feet amsl) that slopes to the north towards the South Fork of the Trinity River. Homer Norris noted that he knew of two Clovis points that had been found there, one a stem fragment on a non-local white, glossy chert (Figure 33) that is $25.0 \mathrm{~mm}$ in width and $6.2 \mathrm{~mm}$ thick, as well as two tan or light gray chert Plainview points. These Late Paleoindian lanceolate points have parallel flaking, a medial ridge on the blade, stem grinding, and concave bases. 


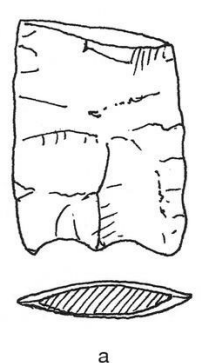

a
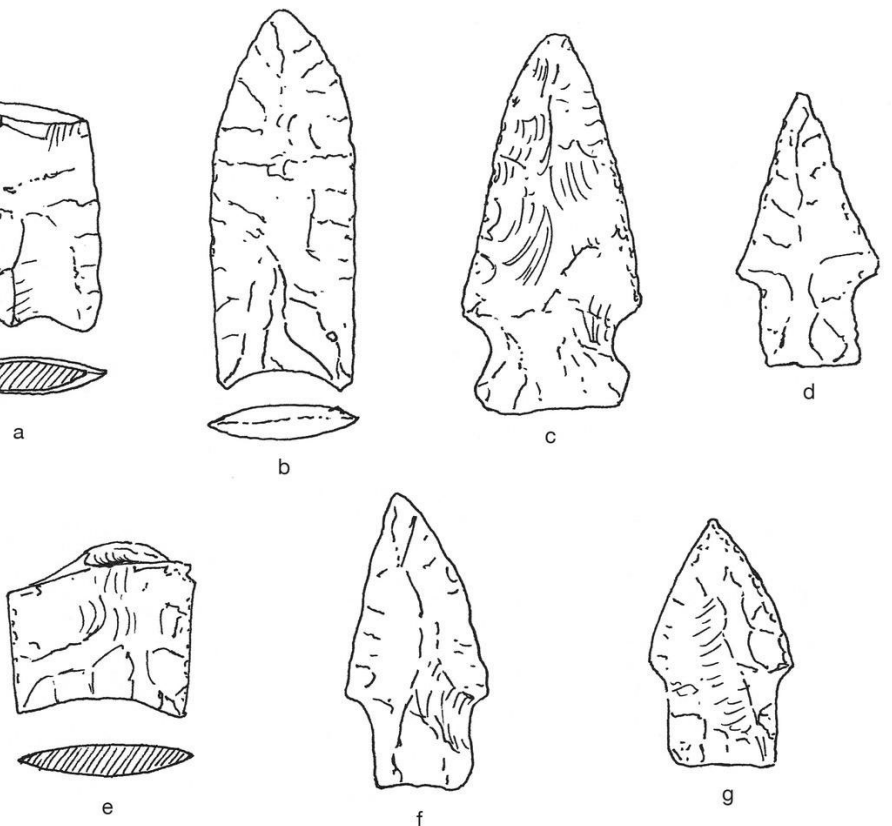

Figure 33. Selected lithic artifacts from the Hull Camp site. Drawings by Homer Norris.

Other artifacts from the site include Middle to Late Archaic dart points (see Figure 33), among them Carrollton, a grayish-brown chert Trinity, and Godley types, and a dart point tip. Also in the Norris collections are a Clear Fork tool (see Turner et al. 2011:225-226), biface fragments, end and side scrapers, flake tools, a sandstone two-sided mano, a brown chert pebble core, and several pieces of chert lithic debris.

\section{Ragle Place}

The Ragle Place is another multi-component Archaic site on an eroded and plowed sandy upland landform in the South Fork of the Trinity River basin. It is west across Burgess Creek from Bell Camp, and is bordered on the north by the South Fork. Middle to Late Archaic dart points were collected from the surface by Norris from the Ragle Place (Figure 34), including Williams, Edgewood, Elam, and
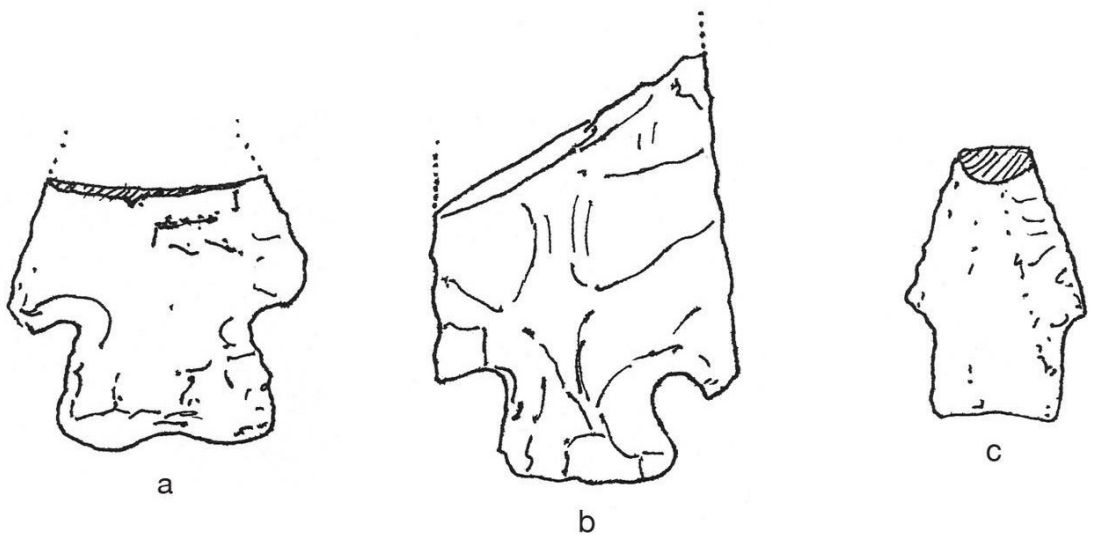

Figure 34. Selected artifacts from the Ragle Place site. Drawings by Homer Norris. 
Ellis points of gray, dark gray, and brown chert. A corner-notched arrow point fragment is in the Norris collection from the site, likely a Scallorn point of light gray chert.

Additional artifacts in the Norris collection from the Ragle Place include both chipped and ground stone tools, including a mano of a limestone conglomerate, chert biface fragments, and a yellow chert drill fragment. There are also chert cores and a single piece of lithic debris in the collection from the site.

\section{Holland Camp}

This prehistoric site is on a upland landform north of the South Fork of the Trinity, in an area of deep sand. In addition to lithic debris and fire-cracked limestone rocks, several Late Archaic dart points of tan to gray chert and quartzite were collected there by Norris (Figure 35), including three Carrollton dart points.
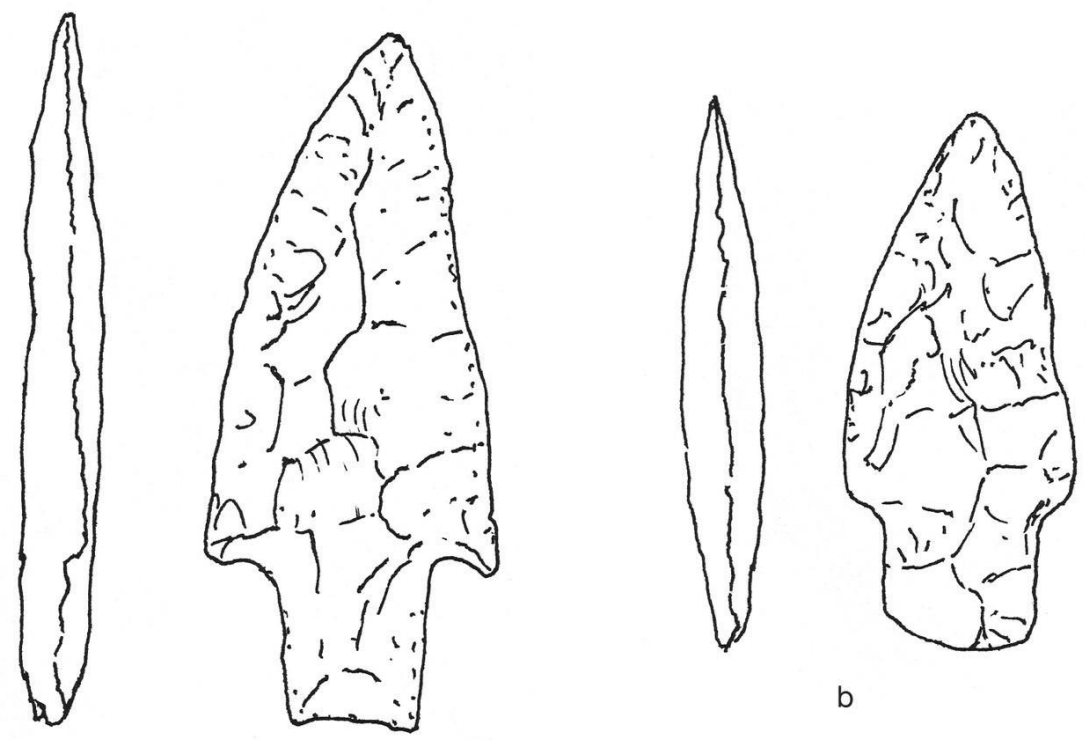

b

a

Figure 35. Dart points from the Holland Camp site. Drawings by Homer Norris.

\section{Burgess Creek Site}

The Burgess Creek site was found by Norris on an eroded sandy upland landform by Burgess Creek, a spring-fed tributary to the South Fork. There are several eroded "canyons" along the edge of the landform, and Norris reported that Native American burials were present there. He collected a tan chert Late Archaic Ellis dart point from the site (Figure 36).

\section{Crane Site}

This prehistoric site of unknown age is on an upland ridge to the immediate west and northwest of Tim Slaton's site. Norris found on the eroded surface a tan-gray chert ovoid biface and a scraper. 


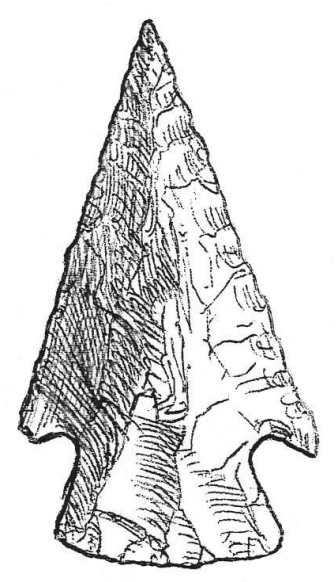

Figure 36. Ellis dart point from the Burgess Creek site. Drawing by Homer Norris.

\section{Grape Vine Site}

Late Archaic dart points (Figure 37) were collected by Homer Norris on an upland landform south of the Fire Wagon Factory Camp site that he called the Grape Vine site. These were in an area of deeper sand along the edge of the landform with fire-cracked rock, fragmentary sandstone mano and metates, and the two straight-stemmed dart points, one probably a broken tan chert Carrollton point, and the other a tan chert Bulverde point.

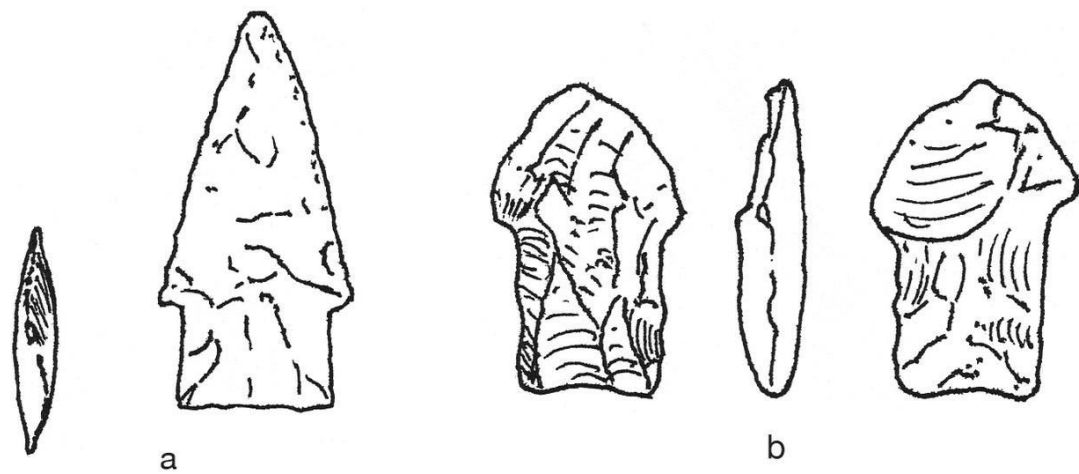

Figure 37. Late Archaic dart points from the Grape Vine site. Drawings by Homer Norris.

\section{Negro School Site}

The Negro School site is on an eroded upland ridge north of the South Fork, not far from the Grace Bison Skeleton site. In addition to a possible Gary dart point, a cf. Darl or Zephyr dart point (see Turner et al. 2011:174) and chipped stone tools (including a grayish-white end scraper), a brown chert dart point tip and medial section, as well as a multi-platform brownish-gray chert core, Norris found a tan chert Clovis point at the site (Figure 38 ). 

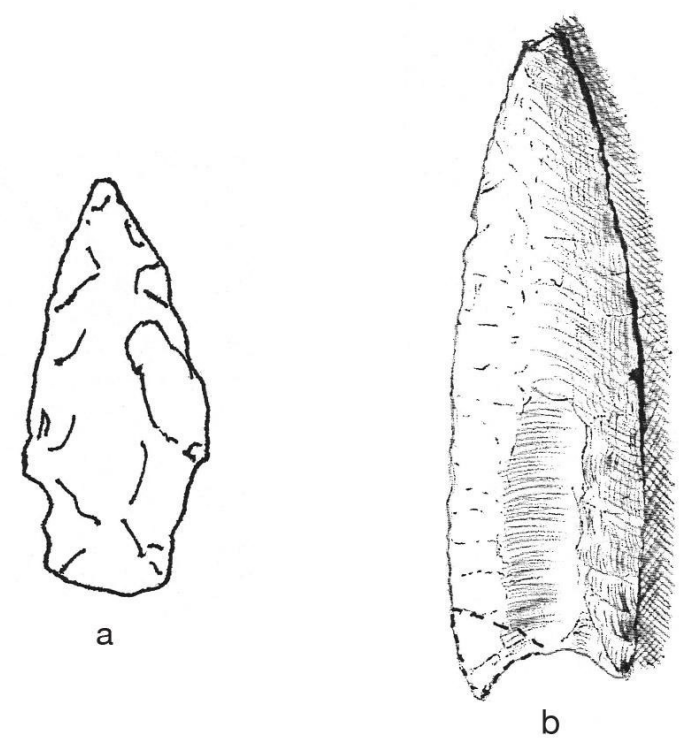

Figure 38. Selected artifacts from the Negro School site. Drawings by Homer Norris.

\section{The Rod Roddy Site}

The Rob Roddy site is a multi-component prehistoric site covering ca. 20 acres on a floodplain landform (840 feet amsl) south of the South Fork of the Trinity River. Norris collected projectile points and other tools, as well as noted much fire-cracked rock, exposed on the surface after the $30 \mathrm{~cm}$ of topsoil, clay, and gravel from the land was removed and sold.

Projectile points found on the site range from Late Paleoindian to Late Prehistoric (Figure 39) in age, and include two extensively resharpened and beveled Early Split Stem or Gower points of pinkish-gray chert and gray chert, a light gray Edgewood point, a tan chert Gary point, an unidentified corner-notched, small barbed, and broad slightly expanding and flat stem dart point of brownish-gray chert, a resharpened mid-section of tan chert, and another dart point mid-section of gray chert. A few pieces of chert lithic debris are also in the Norris collection from the site. At least one Scallorn arrow point (Figure 39g) was found at the site. The only excavations conducted by Norris at the site was in a late $19^{\text {th }}$ century-1928 trash midden associated with an old farmhouse.

\section{Eva Wallis Site}

Norris identified the Eva Wallis site during a reconnaissance of an eroded upland landform in 1967. He noted "a profusion of flint chips" there on a small natural rise, along with two projectile points. One is a probable barbed Alba point of white chert and the other is a dark bluish-brown chert Ellis dart point.

\section{Clayton Wallis Gravel Pit}

Gravel operations in the Burgess Creek area of the South Fork of the Trinity River valley encountered a Late Pleistocene Bison antiquus skull as well as camel and mammoth bones, including a tusk. A profile drawn by Norris of the gravel pit indicates that these bones were recovered at ca. $2.4 \mathrm{~m}$ bs at the base of a tan clayey sand, and above a $2.4 \mathrm{~m}$ thick gravel zone with fossil shells. The only artifact found in 

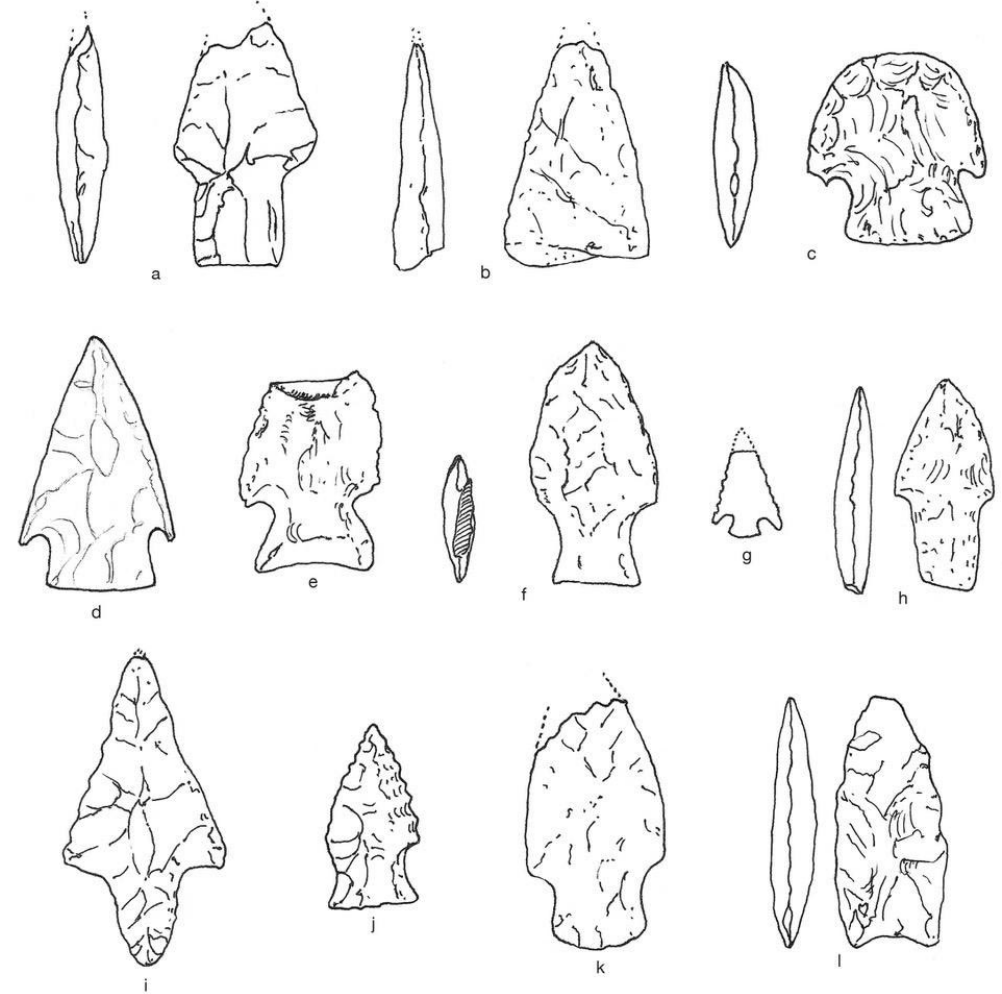

Figure 39. Selected artifacts from the Rob Roddy site. Drawings by Homer Norris.

the gravel pit by Norris is a light gray-gray chert biface $(76.0 \mathrm{~mm}$ in length, $21.1 \mathrm{~mm}$ in width, and 9.0 $\mathrm{mm}$ in thickness) (Figure 40), and his notes state that the biface was "found in the gravel pit after much excavation." This biface has steep unifacial retouch, along with a prominent medial ridge, and may have been used as a cutting tool. Its specific context is not known, nor is it known if this chipped stone artifact was found in association with the extinct fauna also recovered in the gravel pit.

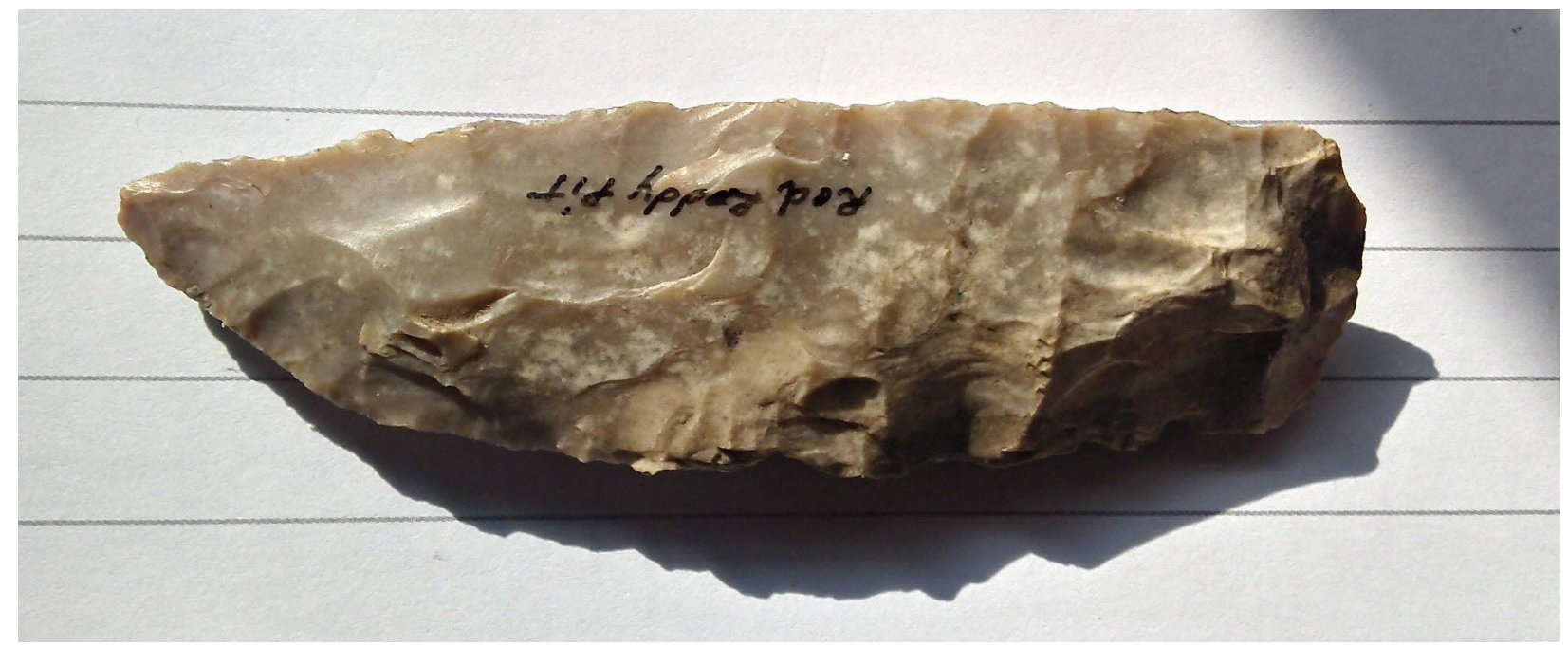

Figure 40. Chert biface from the Clayton Wallis Gravel Pit. 


\section{South Fork Hearth I}

Norris identified a burned rock feature about $3 \mathrm{~m}$ bs at the confluence of two small streams on the south side of the South Fork. The feature was in a paleosol, probably the West Fork Paleosol (see Abbott 2011; Lintz et al. 2008; Quigg et al. 2011) he had previously identified in local streams (see below). In June 1990 he exposed the feature, which was composed of fire-cracked and fire-reddened limestone and an $8 \times 4 \mathrm{~cm}$ piece of sandstone that may be from a metate or grinding slab. The feature was approximately $66 \mathrm{~cm}$ in diameter. Also in the burned rock feature were pieces of wood charcoal up to $4 \mathrm{~cm}$ in length or diameter, abundant snail shells, a mussel shell, and animal bones of deer, rabbit, and rodents. In other parts of the South Fork, Norris identified likely Archaic period burned rock features buried from 2.1-5 m bs.

\section{South Fork Stream and Paleosol}

A wide variety of prehistoric artifacts were collected by Norris in the stream gravels of the South Fork, including the distal end of a grayish-brown opaque chert Folsom point (Figures 41 and 43b) approximately $3.1 \mathrm{~mm}$ thick and a range of Middle to Late Archaic dart points (Figures 42-43) made on chert raw materials. These include a possible Angostura point of dark gray chert, a gray chert split stem dart point (see Prikryl 1990:Figure 24) of Middle Archaic age, a cf. Gower point (Turner et al. 2011:112), dark gray and light gray chert Castroville, Edgewood, Ellis, Godley, and Yarbrough dart points of Late Archaic age, a brown to dark brown Late Archaic Dallas point (see Prikryl 1990), a quartzite Gray point, dart point mid-section fragments of brown and tan chert, a dark gray arrow point preform, and numerous chert biface fragments, including bifacial knives.
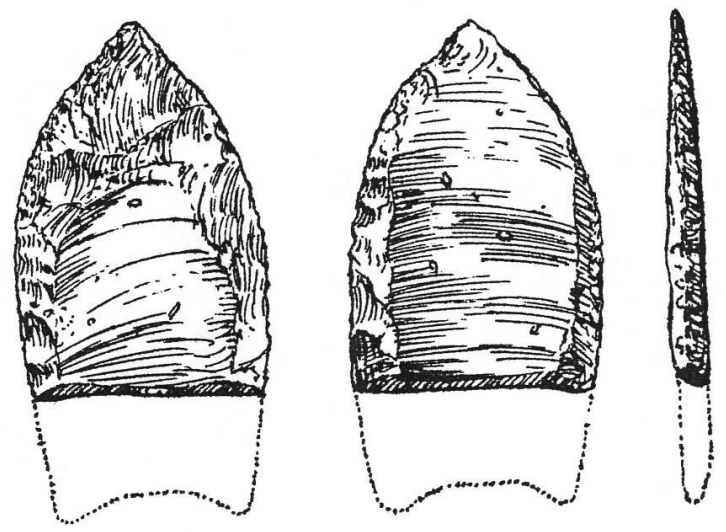

\section{Figure 41. Folsom point from the South Fork of the Trinity River. Drawing by Homer Norris.}

The stream gravels along the South Fork contain an abundance of lithic raw materials for tool manufacture, primarily cherts of different colors, including a yellowish-gray color that he attributes to Brazos River source areas. Norris did note that he found a black obsidian arrow point at one of the sites, although his notes unfortunately do not mention which site. Also found in the gravels are sandstone pieces that were originally from the Woodbine Sandstone Formation.

Norris describes in his notes a ca. 45-60 cm thick dark gray to black paleosol about $2.4 \mathrm{~m}$ bs along the South Fork (and the Clear Fork) that contained in situ Archaic period artifacts; this is most likely the West Fork paleosol (Ferring 1990, 2001), as this paleosol, dated from ca. 3500-860 years B.P., contains 


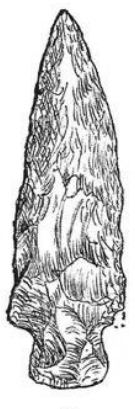

a

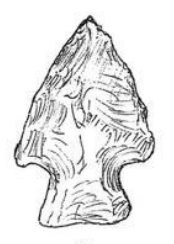

e
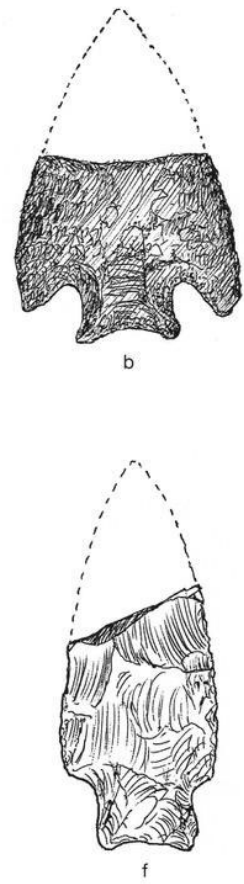
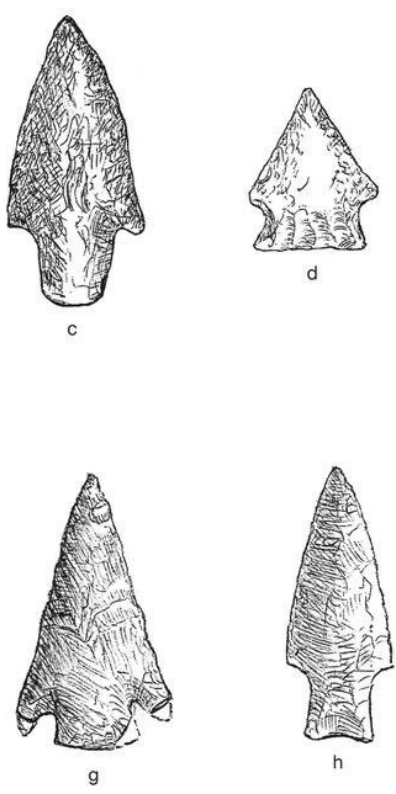

Figure 42. Selected dart points from gravel beds along the South Fork of the Trinity River. Drawings by Homer Norris.

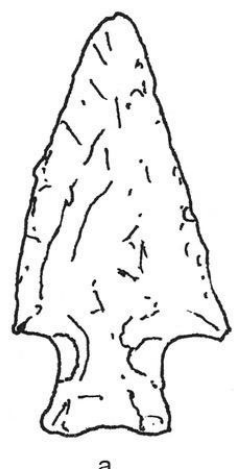

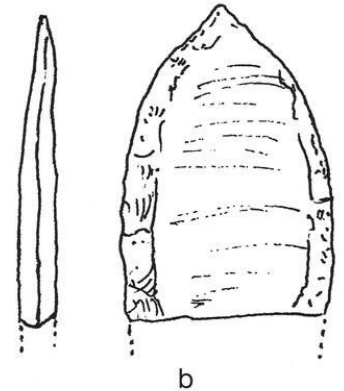
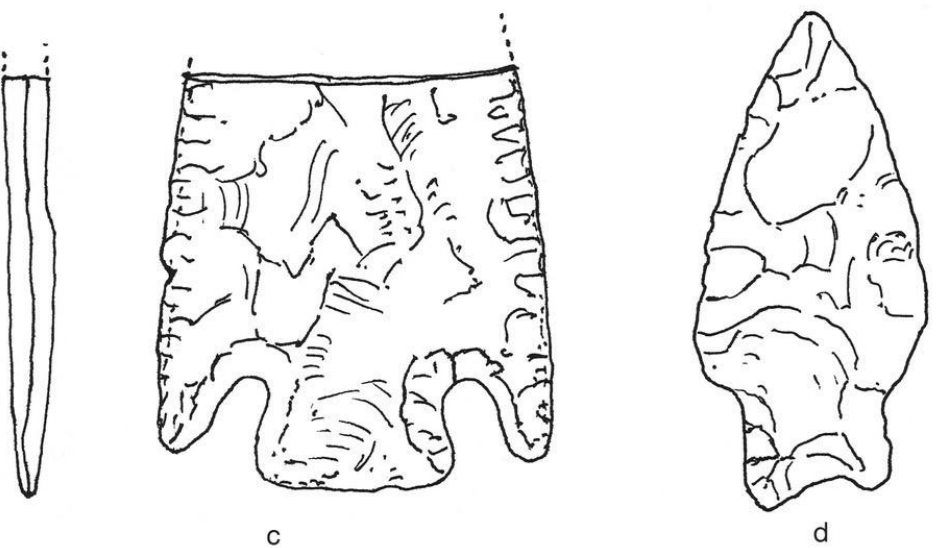

Figure 43. Additional Paleoindian and Archaic dart points from gravel beds along the South Fork of the Trinity River. Drawings by Homer Norris. 
Late Archaic components (Quigg et al. 2011:44). These included many burned rock features (Norris estimated he had located about 30 of these features, which tended to be about $60 \mathrm{~cm}$ in diameter), firecracked and fire-reddened limestone rock and charcoal, mussel shells, burned and unburned animal bone from deer (as well as antler pieces), antelope, bison skull and bone fragments, turtle, birds, small mammals, rodents, snail shells, grinding slabs or metates, a sandstone mano and pitted stone, and chipped stone tools and debris (Figures 44 and 45). Other lithic artifacts from the South Fork paleosol in the Norris collections include chert biface fragments, numerous flake tools, a perforator, chert end scrapers and side scrapers, pieces of lithic debris, and both single platform and multiple platform tan and gray chert cores.

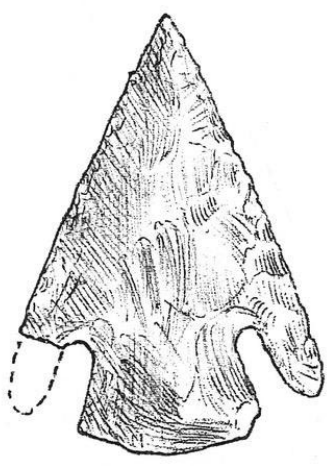

a

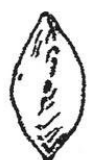

b

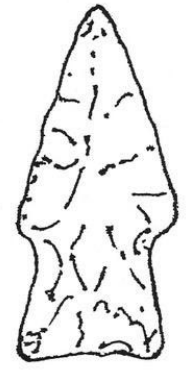

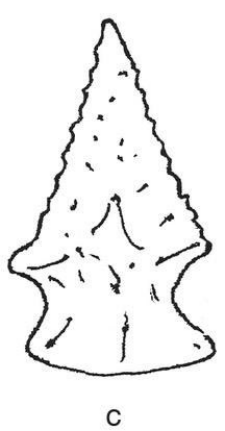

C

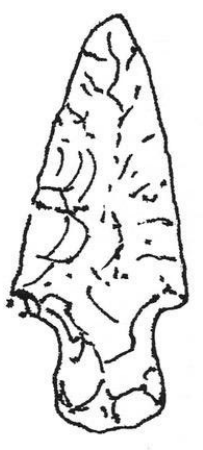

d

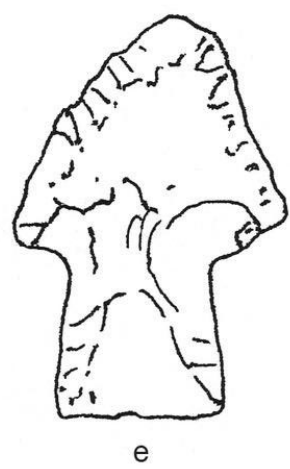

Figure 44. Selected Archaic dart points and tools from South Fork of the Trinity paleosol deposits. Drawings by Homer Norris.

According to Lintz et al. (2008:13), the paleosols in the Trinity River basin were formed during alluvial terrace construction, when "the vegetation cover (probably grasslands) contributed organic carbon at a rate faster than sediment deposition, resulting in a series of buried soils and the accumulation of soils as the terrace treads aggraded." Ferring (1990:47-48) indicates that the prominent West Fork paleosol developed ca. 4525-700 years ago, while Quigg et al. (2011) has refined its age to between 3500-860 years B.P. Both age ranges are consistent with the Late Archaic artifacts and features found in eroded stream gravel contexts along the South Fork and West Fork.

\section{South Fork Bison Remains}

In the Burgess Creek area, the excavation of soil and gravel exposed a "profuse" concentration of bison bones, probably from a kill site. Norris commented that "of course, there are thousands of buried 




Figure 45. Range of artifacts found in paleosol deposits from the South Fork of the Trinity River.

bison skulls and bones all over this country, but only a few of them will be considered [by others] anything more than cow bones.

\section{Clear Fork Stream Finds}

Norris walked the banks and stream gravels of the Clear Fork of the Trinity River and noted the same palesol as he had documented in the banks of the South Fork. Bison bones were noted at several depths in the Clear Fork banks, including a complete skeleton about $2 \mathrm{~m} \mathrm{bs}$, and in another profile, there was a bison skull, lower jaws and teeth, as well as a leg bone, ribs, and scapulae from $2.4 \mathrm{~m}$ bs in the paleosol near the confluence of the Clear Fork and South Fork, along with charcoal and fire-cracked rocks. Stream finds represented in the Norris collections include a reworked Plainview point of gray chert, a possible Paleoindian Hell Gap point of grayish-brown chert (Elton Prewitt, January 2020 personal communication) but possibly instead a reworked Angostura point (Figure 46) (Thomas R. Hester, December 2019 personal communication) of Early Archaic period age (ca. 9800 years ago, based on calibrated radiocarbon dates), a dark gray Middle Archaic Clear Fork adze with a slightly concave working edge, a Late Archaic cornertanged knife, and several Late Archaic chert dart points (including two Castroville points of dark gray chert, three Edgewood points, a cf. Yarbrough point of gray chert, and a cf. Dallas dart point), an early stage biface of brown chert, other chert biface fragments, and scrapers (Figure 47) and flake tools, as well as a pitted stone, chert cores, lithic debris, mussel shell valves, animal bones, and teeth. 


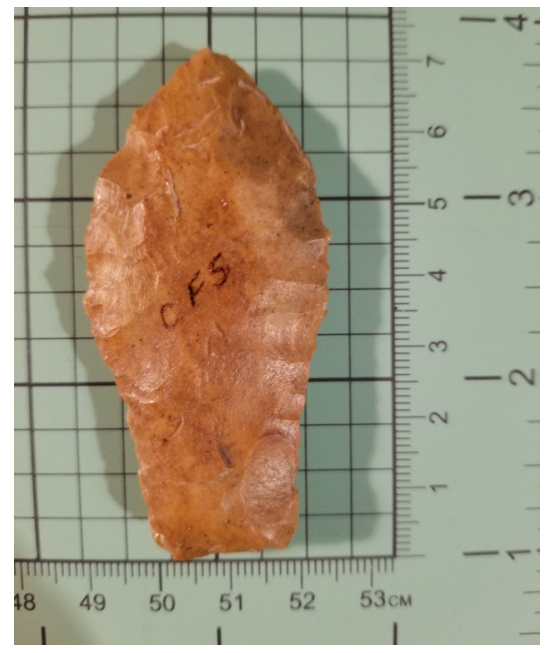

Figure 46. Possible Hell Gap or Angostura point from Clear Fork of the Trinity River gravels.
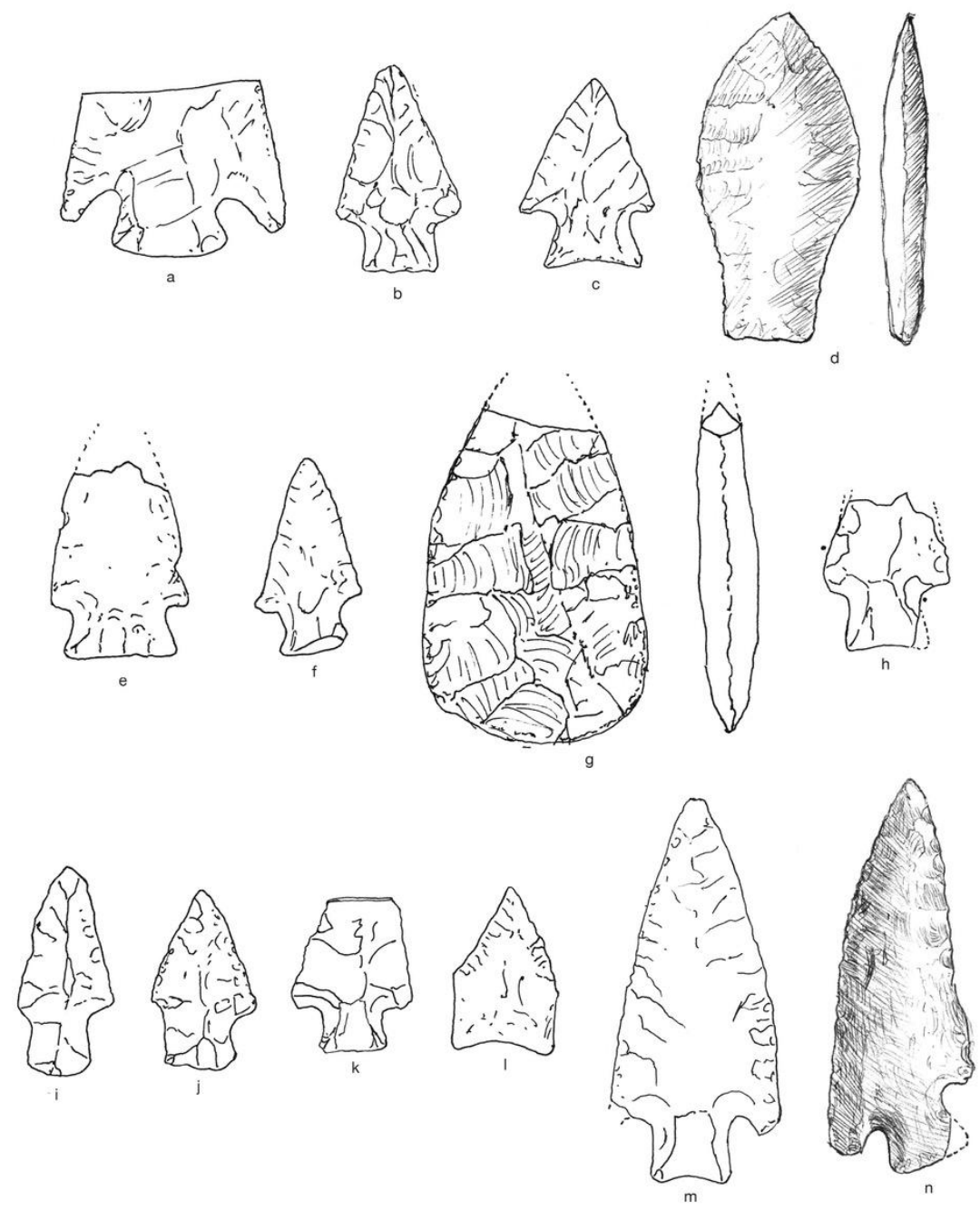

Figure 47. Selected artifacts from the Clear Fork of the Trinity River gravel beds. Drawings by Homer Norris. 
In 1973, Mary Lane Norris, now Lanie Garmon, identified bison remains (a horn core protruding from the bank) about 0.25 miles north of the confluence of the South Fork and Clear Fork, and ca. $1.5 \mathrm{~m}$ bs, but not in the aforementioned paleosol. Upon excavation by Norris, the skull was exposed, along with its extended front legs and portions of the articulated spine, and scapula. These were laying on its left side in a 2-4 cm thick lens of ash and fire-reddened soil. No chipped stone tools were found in association with this bison, but it likely was killed and butchered by Native American hunters, perhaps in Late Prehistoric times. 


\section{Summary of the Investigations by Homer Norris in Parker County}

Homer Norris conducted archeological investigations in Parker County, Texas, in the upper South Fork and Clear Fork of the Trinity River for many years, identifying and recording sites, and preparing detailed notes and artifact drawings on the sites he found in this part of the Blackland Prairie and Western Cross Timbers in North Central Texas. In this report, I have brought together those notes, records, and artifact drawings to showcase the archeological finds made by Norris in one discrete area of the Trinity River basin. I also wanted to put on record those findings for those interested in the archeology of the Upper Trinity River basin and the nature of the archeological sites and material culture assemblages documented from them (see also Todd et al. 2009).

Norris' diligent collecting and recording activities from 20 different prehistoric sites, as well as collecting activities along the cut banks and stream finds of the South Fork and Clear Fork of the Trinity River, have shown that the area was used by ancestral Native Americans from ca. 13,400 years ago to 300-400 years ago, if not later, from Clovis spear points to European glass trade beads. But that use was apparently intermittent and seasonal in nature, except perhaps at the Bell Camp site (41PR107) where the Late Prehistoric (ca. A.D. 900-1450) deposits were more sustained, with evidence of post holes from a structure, and quantities of prehistoric ceramic sherds, arrow points, and a variety of chipped and ground stone tools. There is evidence of violence about 1000 years ago in one of the burial features at 41PR12, along with the ritual use of ochre pigments.

However, much of the use of the upper South Fork and Clear Fork of the Trinity River was during the Archaic, from ca. 10,000 to 1250 years ago. The Archaic is divided into Early (ca. 10,000-8000 years ago), Middle (ca. 8000-5000 years ago), and Late (ca. 5000-1250 years ago) periods, with sites that have smaller notched and stemmed dart points employed with the atlatl. The increased number of point types in the Middle Archaic, and especially the Late Archaic, may indicate regional population growth of aboriginal groups. The subsistence pattern was diversified, and included hunting large and small game and gathering plants with the emergence of a broad-spectrum subsistence pattern at sites where all parts of the landscape were exploited for resources; bison was occasionally utilized during Late Archaic and Late Prehistoric times. Sites are common on terraces, buried in alluvial deposits and cut banks, and are on upland ridges and slopes and readily recognized though the presence of burned rock employed in hot rock cooking activities in earth ovens, boiling pits, and discard piles. Their cooking strategy focused on exploitation of bulk roots and tubers, as well as various nuts and grasses.

Stone tool assemblages included manos, metates, and abraders. Other stone tool types include gouges, various bifaces, drills, scrapers, corner-tanged knives, and edge-modified flakes.

The Late Prehistoric period in the upper Trinity River basin and in what is now Parker County saw the introduction of the bow and arrow and the use-even though minimal, and mostly based on the acquisition in trade from the East Texas Caddo - of pottery vessels for cooking. That period, as mentioned above, is best represented at the Bell Camp site after ca. A.D. 900 to as late as the mid$15^{\text {th }}$ century. Arrow points present at this time included Scallorn, Alba, Bonham, Perdiz, and Washita types. In honor of Homer Norris, one distinctive arrow point form has been designated as Washita, var. Norris. Ground stone (e.g., manos, shallow metates, and pitted stones) are indicative of continued plant processing in the Late Prehistoric. The diet breath of the Native American groups was broad and game resources procured included bison, deer, antelope and a vast array of smaller game, along with fish and mussels. 


\section{References Cited}

Abbott, J. T.

2011 Geoarcheology in North-Central Texas: A Framework for Archeological Investigation, and Cultural Resource Management in the Fort Worth Highway District. Archeological Studies Program Report No. 120. Texas Department of Transportation, Environmental Affairs Division, Archeological Studies Program, Austin.

Becerra-Valdivia, L., M. R. Waters, T. W. Stafford, Jr., S. L. Anzick, D. Comeskey, T. Deviese, and T. Highham

2018 Reassessing the Chronology of the Archaeological Site of Anzick. PNAS.18036241115, pp. 1-4.

Black, S. L. and A. V. Thoms

2014 Hunter-Gatherer Earth Ovens in the Archaeological Record: Fundamental Concepts. American Antiquity 79(2):203-226.

Brooks, R. L.

1989 Village Farming Societies. In From Clovis to Comanchero: Archeological Overview of the Southern Great Plains, by J. L. Hofman, R. L. Brooks, J. S Hays, D. W. Owsley, R. L. Jantz, M. K. Marks, and M. H. Manhein, pp. 71-90. Research Series No. 35. Arkansas Archeological Survey, Fayetteville.

Carr, C.

1995 Mortuary Practices: Their Social, Philosophical-Religious, Circumstantial, and Physical Determinants. Journal of Archaeological Method and Theory 2(2):105-200.

Circelli, Jerry

1997 "Fossil hunter." Fort Worth Star-Telegram, May 13, 1997. Article reprinted in the TCAS Benchmark 11(6): 3-4.

Diamond, D. D., D. H. Riskind, and S. L. Orzell

1987 A Framework for Plant Communities Classification and Conservation in Texas. Texas Journal of Science 39(3):203-221.

Dockall, H. D.

1997 Archaic Hunter-Gatherer Adaptation on the Inland Portion of the West Gulf Coastal Plain: The Bioarchaeological Evidence. Ph.D. dissertation, Department of Anthropology, Texas A\&M University, College Station.

Ellis, L. W., T. K. Perttula, and W. W. Crook, III

2015 Aboriginal Ceramics from the North Central Region of Texas. Bulletin of the Texas Archeological Society 86:159-191.

Everett, J.

1989 Two Red Ochre Burials from 41PR12. The Letter (Newsletter of the Tarrant County Archeological Society) 3(3):3-7.

1990 The Grace Bison Skeleton Site-41PR20. The Letter (Newsletter of the Tarrant County Archeological Society) 4(4):4-9. 
Ferring, C. R.

1990 Late Quaternary Geology and Geoarchaeology of the Upper Trinity River Drainage Basin, Texas. Guidebook Field Trip \#11. Geological Society of America.

2001 The Archaeology and Paleoecology of the Aubrey Clovis Site (41DN479), Denton County, Texas. Center for Environmental Archaeology, Department of Geography, University of North Texas, Denton.

Fields, R. C., K. W. Kibler, E. F. Gadus, D. K. Boyd, and T. B. Griffith

2005 Archeological Impact Evaluations and Surveys in the Texas Department of Transportation's Abilene, Austin, Brownwood, Bryan, Fort Worth, Waco, and Yoakum Districts, 2001-2003. Reports of Investigations No. 143, Prewitt \& Associates, Inc., and Report No. 83, Archeological Studies Program, Environmental Affairs Division, Texas Department of Transportation, Austin.

Hall, G. D.

1995 Descriptions and Chronology of some Prehistoric Cemeteries in Texas. In Archeological Investigations at the Loma Sandia Site (41LK28): A Prehistoric Cemetery and Campsite in Live Oak County, Texas, by A. J. Taylor and C. L. Highley, pp. 47-57. Studies in Archeology 20.2 Vols. Texas Archeological Research Laboratory, The University of Texas at Austin.

Hester, T. R.

1969 Human Bone Artifacts from Southern Texas. American Antiquity 34(3):326-328.

Hofman, J. L. and R. L. Brooks

1989 Prehistoric Culture History: Woodland Complexes in the Southern Great Plains. In From Clovis to Comanchero: Archeological Overview of the Southern Great Plains, by J. L. Hofman, R. L. Brooks, J. S. Hays, D. W. Owsley, R. L. Jantz, M. K. Marks, and M. H. Manhein, pp. 61-70. Research Series No. 35. Arkansas Archeological Survey, Fayetteville.

Kelly, R. L.

1995 The Foraging Spectrum: Diversity in Hunter-Gatherer Lifeways. Smithsonian Press, Washington, D.C.

Leith, L.

2014 Towards a Common Understanding: A Revision of Fourche Maline Chronology in Oklahoma. Caddo Archeology Journal 24:5-28.

Lintz, C., S. A. Hall, T. G. Baugh, and T. Osburn

2008 Archeological Testing at 41TR170, Along the Clear Fork of the Trinity River, Tarrant County, Texas. Miscellaneous Reports of Investigations No. 348. Geo-Marine, Inc., Plano.

Lohse, J. C., S. L. Black, and L. M. Cholak

2014 Toward an Improved Archaic Radiocarbon Chronology for Central Texas. Bulletin of the Texas Archeological Society 85:251-279.

Martin, E. R.

1994 The Dillard Site: A Late Prehistoric Plains Village Site in Cooke County, Texas. Bulletin of the Texas Archeological Society 62:105-200. 
Mauldin, R. P. and A. L. Figueroa

2006 Data Recovery Excavations at 41PR44, Fort Wolters, Parker County, Texas. Archaeological Report No. 369. Center for Archaeological Research, The University of Texas at San Antonio.

McWilliams, J. K., R. C. Fields, K. W. Kibler, E. F. Gadus, D. K. Boyd, and T. B. Griffith

2006 Archeological Impact Evaluations and Surveys in the Texas Department of Transportation's

Abilene, Brownwood, Fort Worth, and Waco, Districts, 2003-2006. Reports of Investigations No. 148, Prewitt \& Associates, Inc., and Report No. 93, Archeological Studies Program, Environmental Affairs Division, Texas Department of Transportation, Austin.

Newell, H. P and A. D. Krieger

1949 The George C. Davis Site, Cherokee County, Texas. Memoir No. 5. Society for American Archaeology, Menasha, Wisconsin.

Norris, $\mathrm{H}$.

2006 Parker County Prairie Sketchbook: Prehistory, History, Customs, Places, and Memories. Privately published, Annetta, Texas.

Owsley, D. W.

1989 The History of the Bioarchaeological Research in the Southern Great Plains. In From Clovis to Comanchero: Archeological Overview of the Southern Great Plains, by J. L. Hofman, R. L. Brooks, J. S. Hays, D. W. Owsley, R. L. Jantz, M. K. Marks, and M. H. Manhein, pp. 123-136. Research Series No. 35. Arkansas Archeological Survey, Fayetteville.

Owsley, D. W. and R. L. Jantz (editors)

2014 Kennewick Man. Texas A\&M University Press, College Station.

Patterson, L. W., W. M. Black, W. L. McClure, R. Storey, and S. Patrick

1993 Excavations at the Bowser Site, 41FB3, Fort Bend County. Report No. 9. Houston Archeological Society, Houston.

Perttula, T. K.

2001 Hunter-Gatherer Mortuary Practices in the Rio Grande Plains and Central Coastal Plains Archeological Regions of Texas. La Tierra 28(3/4):2-83.

2015 The Peterson Ranch Site (41HS253), A Late $17^{\text {th }}$ to Early $18^{\text {th }}$ Century Ancestral Caddo Cemetery in the Little Cypress Creek Basin, Harrison County, Texas. Journal of Northeast Texas Archaeology 54:1-7.

Peter, D. E. and D. E. McGregor (editors)

1988 Late Holocene Prehistory of the Mountain Creek Drainage. Joe Pool Lake Archaeological Project, Volume I. Archaeology Research Program, Institute for the Study of Earth and Man, Southern Methodist University, Dallas.

Prikryl, D. J.

1990 Lower Elm Fork Prehistory. Report 37. Office of the State Archeologist, Texas Historical Commission, Austin. 
Quigg, J. M., P. Matchen, C. D. Frederick, and R. A. Ricklis

2011 Root-be-Gone (41YN452): Data Recovery of Late Archaic Components in Young County, Texas. Archeological Studies Program Report No. 135. Environmental Affairs Division, Texas Department of Transportation, Austin.

Reimer, P. J, E. Bard, A. Bayliss, J. W. Beck, P. G. Blackwell, C. Bronk Ramsey, C. E. Buck, H. Cheng, R. L. Edwards, M. Friedrich, P. M. Grootes, T. P. Guilderson, H. Haflidason, I. Hajdas, C. Hatté, T. J. Heaton, A. G. Hogg, K. A. Hughen, K. F. Kaiser, B. Kromer, S. W. Manning, M. Niu, R. W. Reimer, D. A. Richards, E. M. Scott, J. R., Southon, C. S. M. Turney, and J. van der Plicht

2013 IntCal13 and MARINE13 radiocarbon age calibration curves 0-50000 years cal BP. Radiocarbon 55(4):1869-1887. DOI: $10.2458 /$ azu_js_rc.55.16947

Ricklis, R. A.

1994 Aboriginal Life and Culture on the Upper Texas Coast: Archaeology at the Mitchell Ridge Site, 41GV66, Galveston Island. Coastal Archaeological Research, Corpus Christi.

Roebroeks, W., M. J. Sier, T. K. Nielsen, D. De Loecker, J. M. Pares, C. E. S. Arps, and H. J. Mucher 2012 Use of red ochre by early Neanderthals. Proceedings of the National Academy of Sciences 109(6):1889-1894.

Rohn, A. H.

1998 Haley's Point (34MA15) on the Red River, Marshall County, Oklahoma (Area F). Publications in Anthropology No. 4. Department of Anthropology, Wichita State University, Wichita, Kansas.

Roper, D. C.

1992 A Comparison of Contexts of Red Ochre Use in Paleo-indian and Upper Paleolithic Sites. North American Archaeologist 12:289-301.

Schambach, F. F.

1982 An Outline of Fourche Maline Culture in Southwest Arkansas. In Arkansas Archeology in Review, edited by N. L. Trubowitz and M. D. Jeter, pp. 132-197. Research Series No. 15. Arkansas Archeological Survey, Fayetteville.

Stokes, J. and J. Woodring

1981 Native-Made Artifacts of Clay. In Archeological Investigations at the George C. Davis Site, Cherokee County, Texas: Summers of 1979 and 1980, edited by D. A. Story, pp. 135-238. Occasional Paper No. 1. Texas Archeological Research Laboratory, The University of Texas at Austin.

Story, D. A.

2000 Introduction. In The George C. Davis Site, Cherokee County, Texas, by H. P. Newell and A. D. Krieger, pp. 1-31. 2nd Edition. Society for American Archaeology, Washington, D.C.

Stuiver, M., P. J. Reimer, and R. W. Reimer

2020 CALIB 7.1 at http://calib.org, accessed February 25, 2020.

Suhm, D. A. and E. B. Jelks (editors)

1962 Handbook of Texas Archeology: Type Descriptions. Special Publication No. 1, Texas Archeological Society, and Bulletin No. 4, Texas Memorial Museum, Austin. 
Taylor, A. J.

1995 Summary and Consideration of Cultural Features. In Archeological Investigations at the Loma Sandia Site (41LK28): A Prehistoric Cemetery and Campsite in Live Oak County, Texas, by A. J. Taylor and C. L. Highley, pp. 359-404. Studies in Archeology 20. 2 Vols. Texas Archeological Research Laboratory, The University of Texas at Austin.

Thoms, A. V. (editor)

1994 The Valley Branch Archaeological Project: Excavations at an Archaic Site (41MU55) in the Cross Timbers Uplands, North-Central Texas. Reports of Investigations No. 15. Archaeological Research Laboratory, Texas A\&M University, College Station.

Todd, J., M. Glasgow, H. Norris, and B. Lang

2009 Prehistoric Archeology along a portion of the Clear and South Forks of the Trinity River, Parker County, Texas. The Record 56(1):47-57.

Turner, E. S., T. R. Hester, and R. L. McReynolds

2011 Stone Artifacts of Texas Indians. Taylor Trade Publishing, Lanham, Maryland.

Wreschner, E. E.

1980 Red Ochre and Human Evolution: A Case for Discussion. Current Anthropology 21:631-633. 